\author{
UNIVERSIDADE DE \\ BRASÍLIA \\ INSTITUTO DE ARTES \\ DEPARTAMENTO DE MÚSICA \\ PROGRAMA DE PÓS-GRADUAÇÃO MÚSICA EM CONTEXTO
}

\title{
TRADIÇÃO E INOVAÇÃO \\ NO CAVAQUINHO BRASILEIRO
}

LUIS CARLOS ORIONE DE ALENCAR ARRAES

BRASÍLIA 


\section{LUIS CARLOS ORIONE DE ALENCAR ARRAES}

\section{TRADIÇÃO E INOVAÇÃO \\ NO CAVAQUINHO BRASILEIRO}

Dissertação apresentada ao Programa de Pós-graduação "Música em Contexto" do Instituto de Artes da Universidade de Brasília na área de concentração em Musicologia, sob orientação da Prof ${ }^{a}$. Dr ${ }^{a}$. Beatriz Duarte Pereira de Magalhães Castro

\section{BRASÍLIA}


Ficha catalográfica elaborada automaticamente, com os dados fornecidos pelo(a) autor(a)

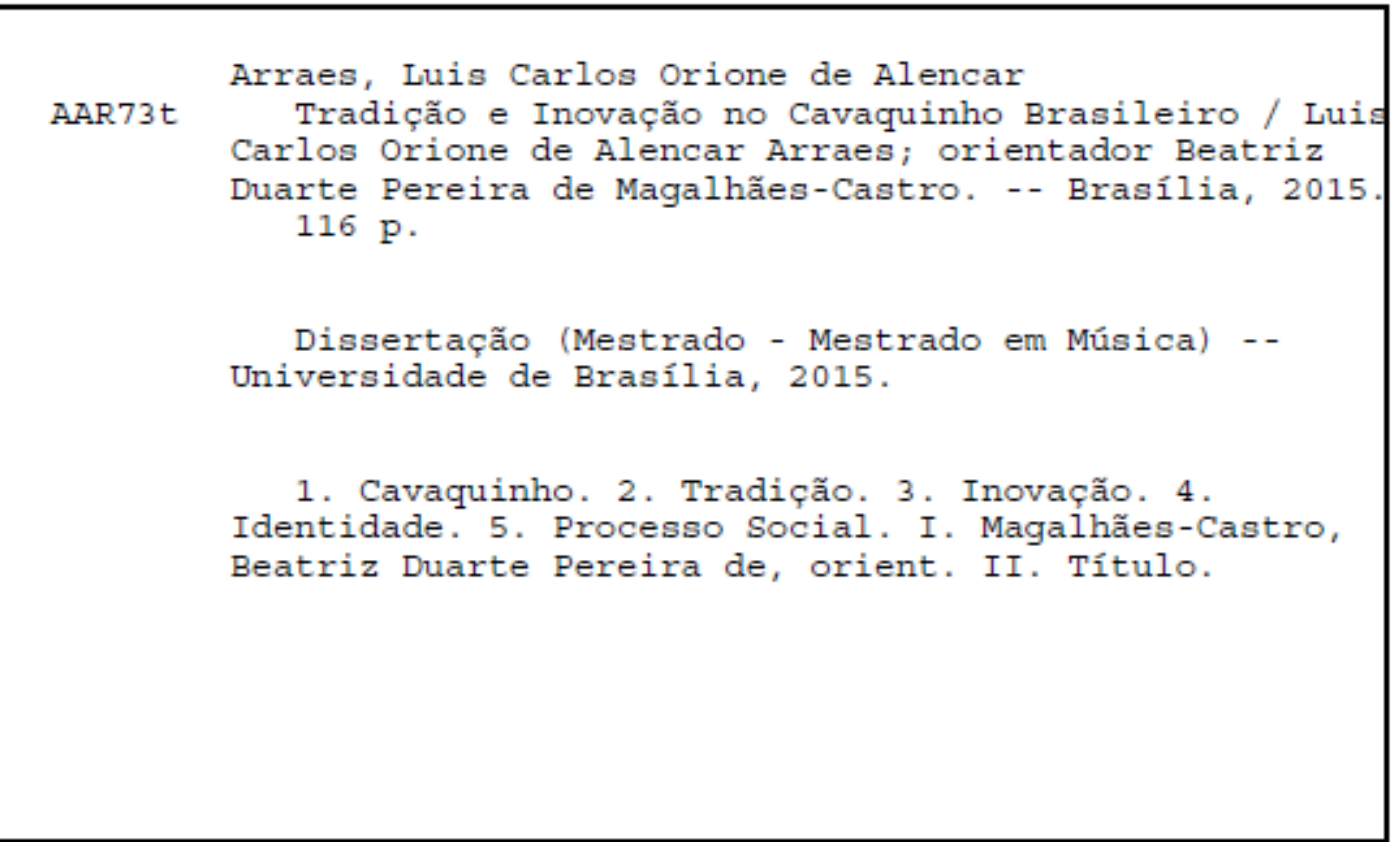




\title{
LUIS CARLOS ORIONE DE ALENCAR ARRAES
}

\author{
TRADIÇÃO E INOVAÇÃO \\ NO CAVAQUINHO BRASILEIRO
}

Dissertação apresentada ao Programa de Pós-graduação em Música do Departamento de Música da Universidade de Brasília - UnB, como parte dos requisitos necessários à obtenção do título de Mestre em Música.

Orientadora: Prof ${ }^{\mathrm{a}}$. Dr ${ }^{\mathrm{a}}$. Beatriz Duarte Pereira de Magalhães Castro

Banca Examinadora

Beatriz Duarte Pereira de Magalhães Castro

(orientadora)

Universidade de Brasília - UnB

Ricardo Dourado Freire (Membro Interno)

Universidade de Brasília - UnB

André Guerra Cotta (Membro Externo)

Universidade Federal Fluminense - UFF 
Dedico esta pesquisa aos meus filhos André Felipe e Santiago e ao meu neto Nuno. 


\section{AGRADECIMENTOS}

Primeiramente, agradeço a minha mãe Catarina Orione Arraes (in memorian) que me colocou no mundo e me apoiou por uma vida inteira e ao meu pai Carlos de Alencar Arraes (in memorian) pelo cavaquinho e pela paciência.

A Professora Doutora Beatriz Duarte Pereira de Magalhães Castro, minha orientadora, por todos os ensinamentos e ideias que foram fundamentais na elaboração desta pesquisa.

A minha amiga Rosana Gonçalves pelo apoio e incentivo na construção do meu projeto apresentado na seleção de admissão no mestrado.

A minha esposa Paula Leite pelo carinho, compreensão e incentivo.

Ao meu filho André Felipe pelo incentivo, aos meus irmãos Eliane e Paulo e toda minha família pela paciência.

Aos meus sogros Carlos Antônio e Suely pelo incentivo e fontes bibliográficas.

Ao meu professor de cavaquinho Luciano que me ensinou os primeiros segredos do cavaquinho e me colocou em contato com o choro e com o samba.

A todos os colegas de mestrado pelos debates e pela boa companhia, em especial, a Heverson Nogueira, Daniel Baker e Gabriel Pardal, pelas dicas.

Aos músicos Henrique Cazes, Roberto Corrêa, Márcio Marinho, Júnior Fernandes, Marco César de Oliveira Brito, Jorginho do Pandeiro, Raffael Santana da Silva, Jorge Cardoso, João Ferreira, Carlos Pial e Léo Benon pelas informações concedidas.

Aos músicos Diana Mota, Vitor Angeleas, Kaio Graco, João Vitor, Guilherme Maia e Isabella Pina pela foto com os instrumentos.

A amiga Martita Ghirlanda pelas fontes bibliográficas e pelas sugestões.

Ao meu aluno Mauro Amorim pelas medidas do cavaquinho modelo Paulistinha.

Aos Professores Doutores Ricardo Dourado Freire e André Guerra Cotta que fizeram parte da minha banca examinadora. 


\section{CAVAQUiNho}

Menino preto

Cabelo Sapecado

Olhos grandes riscados de sangue

Vem pedir alta noite:

"O cavaquinho dos guri"

De tanto uso

E já gasto

O cavaquinho jazia

Frio e sem dono

Em pleno abandono

Da noite o pedido

$\mathrm{O}$ fez ressurgir

E abraçado ao menino

Lá se foi pra favela

Sentir a batucada

Samba de morro

Alta madrugada

Rolaste piso liso

Hoje rei de chão batido

Eu te ouço toda a noite

"Da casa dos guri"

E te peço cavaquinho

Faze feliz tanta gente

Que canta e precisa de ti.

(KAUTZMANN, 1969, p. 15) 


\section{RESUMO}

O presente trabalho se refere aos aspectos histórico-sociais que vieram a consolidar uma tradição na maneira de se tocar o cavaquinho no Brasil, fazendo uma abordagem desde a sua origem, sua chegada ao nosso país, e sua participação na construção de uma identidade cultural nacional. Esse trabalho nos traz ainda uma reflexão sobre a música como processo social constante em um mundo de multiculturalidades, possibilitando, a todo o momento, em qualquer época, o surgimento de uma inovação na maneira de fazer música, de executar um instrumento.

Palavras chaves: Cavaquinho; Tradição; Inovação; Identidade; Processo Social. 


\begin{abstract}
This work refers to the historical and social aspects that consolidated tradition in a manner of cavaquinho playing, its origins, its arrival in Brazil and its participation in the construction of a national cultural identity. This work also reflects on music as an ever-present social process, in a multicultural oriented world, which allows anywhere and anytime, spontaneous innovations in making music and instrumental playing.
\end{abstract}

Key Words: Cavaquinho; Tradition; Innovation; Identity; Social Process. 


\section{LISTA DE FIGURAS}

Figura 1 - Classificação SHV (Hornbostel \& Sachs), seção Cordófonos (3) ............... 24

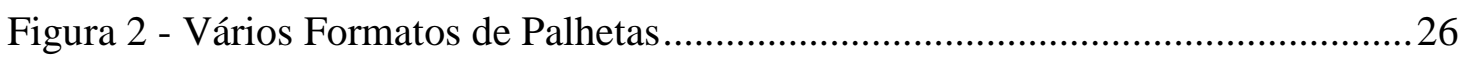

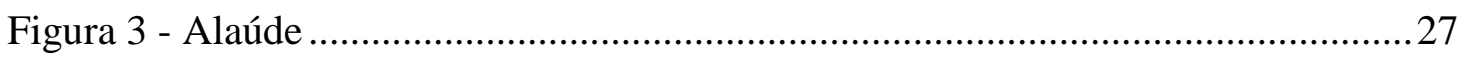

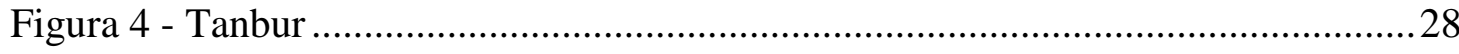

Figura 5 - Escultura de Benedetto Antelami, em uma porta do Batistério de Parma, séc.XII. .29

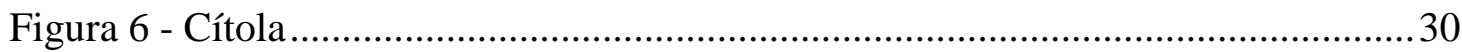

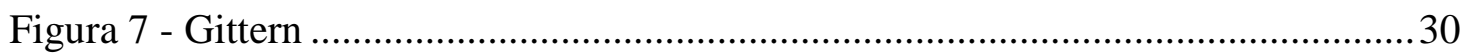

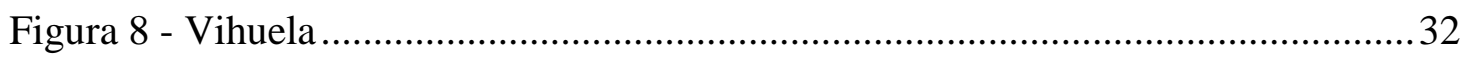

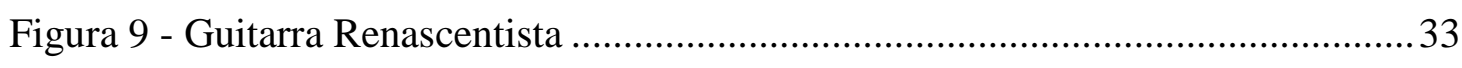

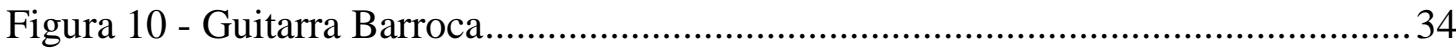

Figura 11 - Guitarra Romântica construída por Francois Roudhlof, por volta de 1820.

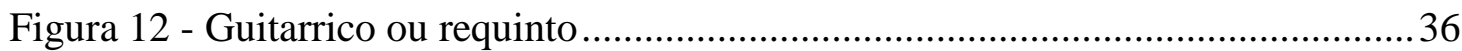

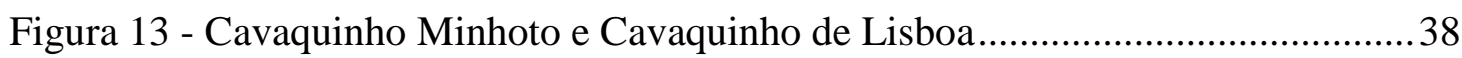

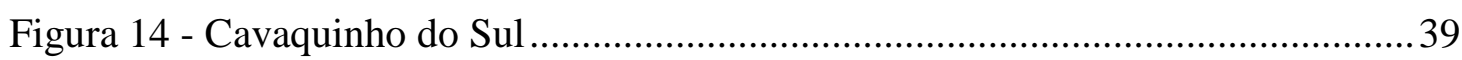

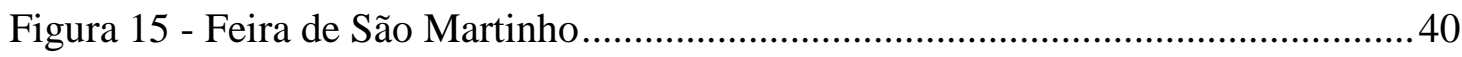

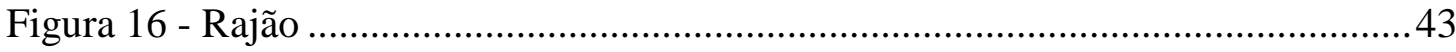

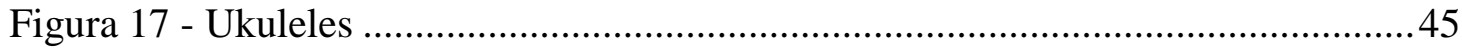

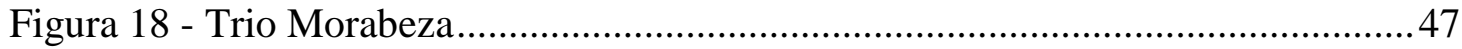

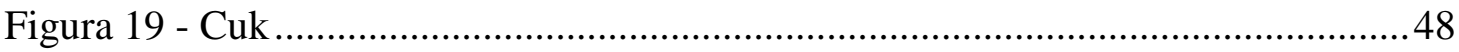

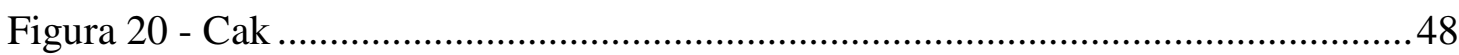

Figura 21 - Cavaquinho modelo Paulistinha e o cavaquinho convencional .................51

Figura 22 - Cavaquinhos convencional e modelo Canhoto .........................................52

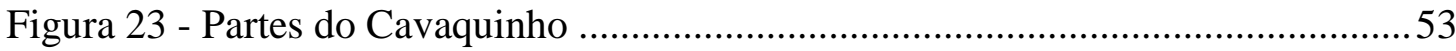

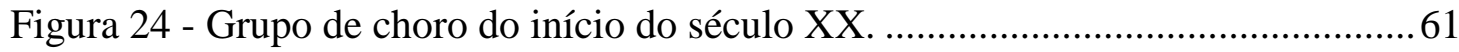

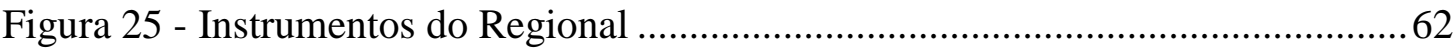

Figura 26 - Heitor dos Prazeres, cavaquinista, compositor e pintor,com um cavaquinho de cinco cordas.

Figura 27 - Roda de Samba. Óleo de Heitor dos Prazeres............................................ 70

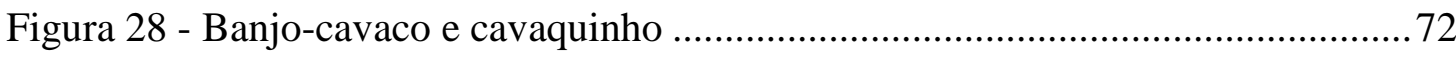

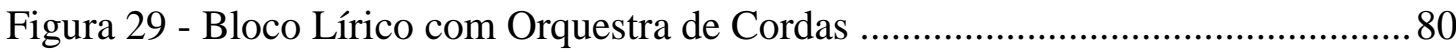




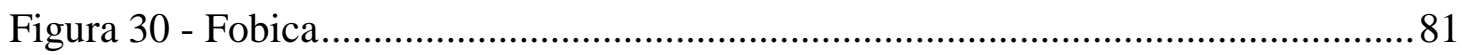

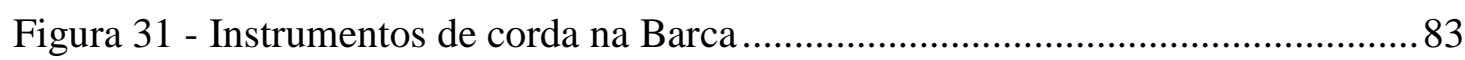

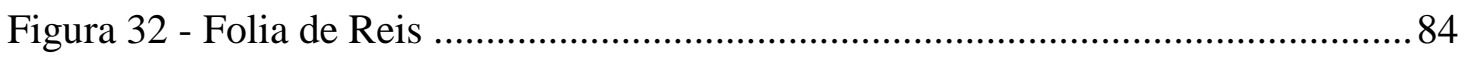

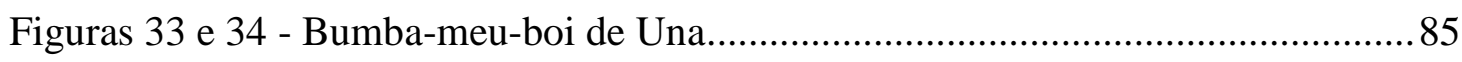

Figura 35 - Waldir Azevedo ................................................................................. 94

\section{LISTA DE TABELAS}

Tabela 1 - Classificação Hornbostel \& Sachs seção Cordófonos (3) .............................. 21

Tabela 2 - Legenda da Classificação SVH (Hornbostel \& Sachs), seção Cordófonos (3) 


\section{SUMÁRIO}

INTRODUÇÃO

CAPITULO 1 - CAVAQUINHO SEUS ANCESTRAIS, SUA ORIGEM, SUA TRAJETÓRIA ATÉ O BRASIL 19

1.1 - O cavaquinho e o sistema de Hornbostel \& Sachs 19

1.2 - A palheta ou plectro 25

1. 3 - Os ancestrais: alaúde, tanbur, cítala e gittern 26

1.4 - A vihuela, a guitarra renascentista, a guitarra barroca, a guitarra romântica, o requinto 31

1.4.1 - A Vihuela 31

1.4.2 - A Guitarra Renascentista 33

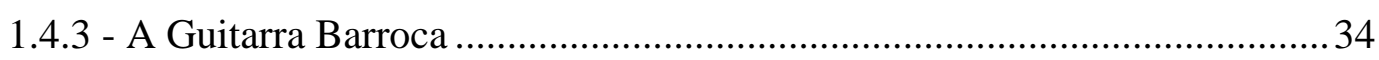

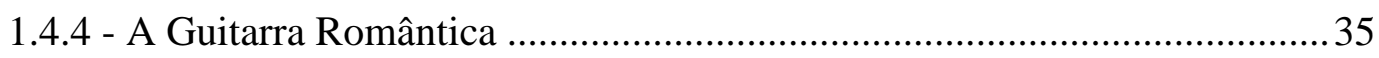

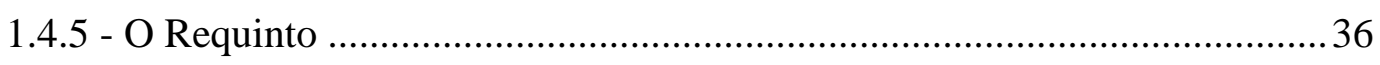

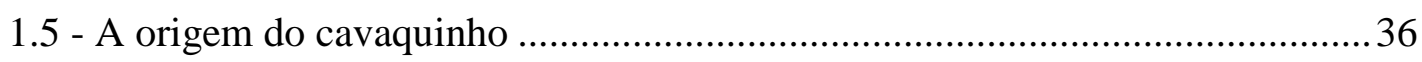

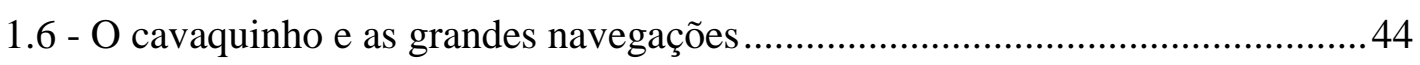

CAPÍTULO 2 - O CAVAQUINHO TRADICIONAL BRASILEIRO .........................50

2.1 - Contribuições ameríndias, portuguesas e africanas........................................54

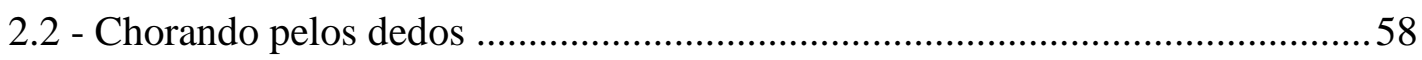

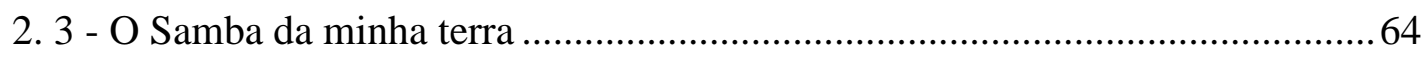

2.4 - O cavaquinho em outros gêneros musicais e no folclore ................................ 73

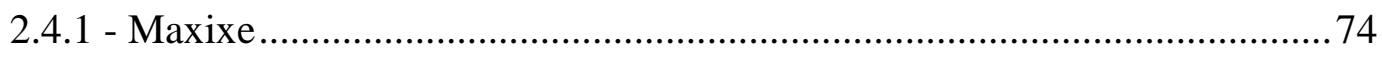

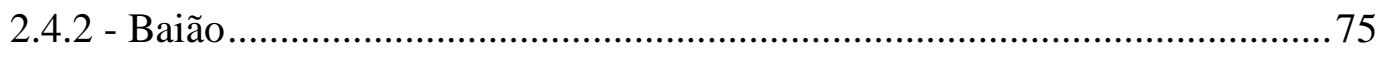

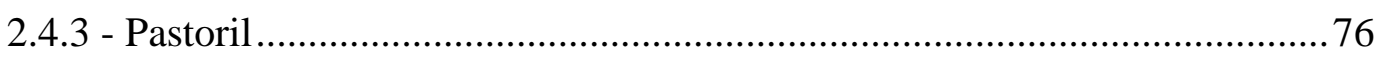

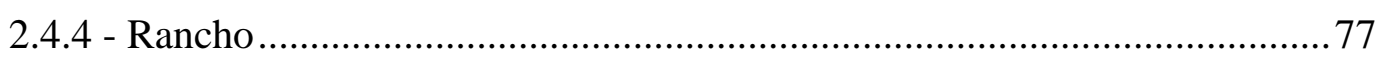

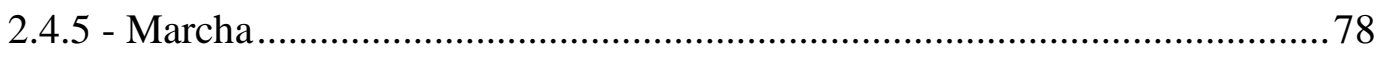

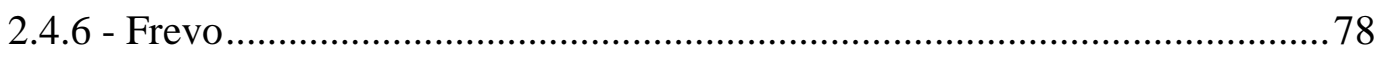




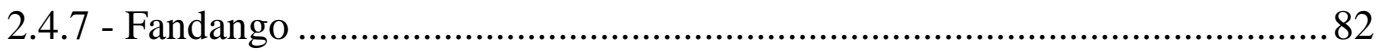

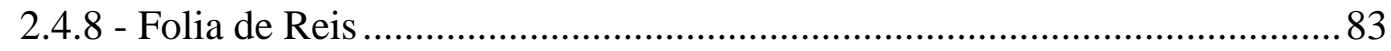

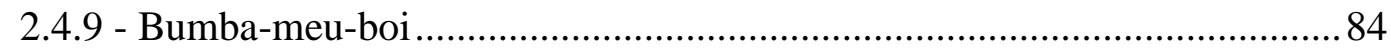

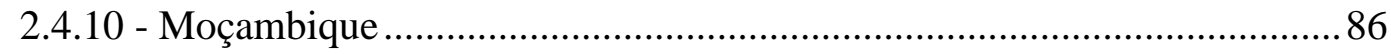

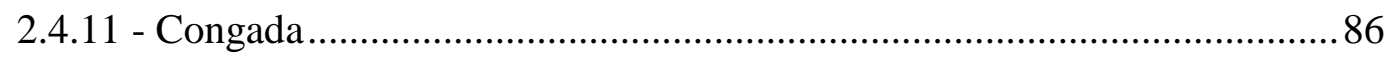

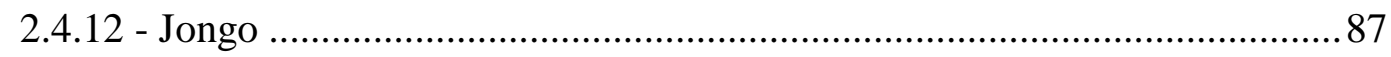

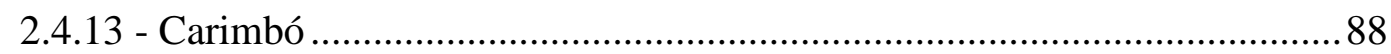

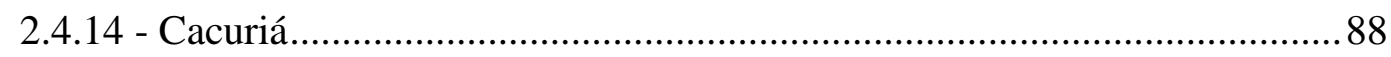

CAPÍTULO 3 - UMA NOVA MUDANÇA, EM BREVE, VAI ACONTECER......... 90

3.1 - A música como processo social num mundo multicultural............................ 90

3.2 - Cavaquinistas no processo tradição-inovação................................................91

3. 3 - Aspectos sobre os processos de tradição-inovação-(nova) tradição............... 105

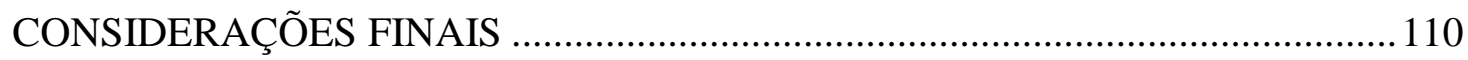

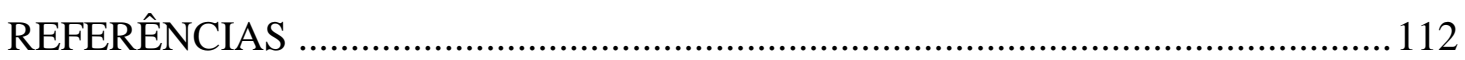




\section{INTRODUÇÃO}

Esta pesquisa nasce do meu desejo de aprofundar os conhecimentos sobre a história do cavaquinho. Ela é fruto da minha curiosidade e do meu encanto pelo instrumento que chegou ao Brasil pelas mãos dos colonizadores portugueses e, desde então, vem nutrindo o imaginário de brasileiros de várias gerações, contribuindo fortemente na formação da música popular brasileira. A beleza dos acordes misturada aos aspectos de tradição e inovação forma o percurso de leituras que dão corpo a este estudo.

Impulsionado pela minha curiosidade, como cavaquinista, professor e compositor, este trabalho nos traz ainda uma reflexão sobre a música como um processo social constante em um mundo de multiculturalidade, que possibilita, a todo o momento, e em qualquer época, inovações na maneira de fazer música e de executar um instrumento.

Segundo J.N.Forkel, primeiro musicólogo alemão genuíno e biógrafo de Bach, a música pela qual os musicólogos se interessam é aquela que faz parte de sua cultura, de sua própria tradição nacional ou, em se tratando de sacra, de sua religião (KERMAN, 1985, p.35).

Apesar da relevante contribuição desse instrumento à cultura brasileira, verifica-se uma reduzida quantidade de trabalhos acadêmicos sobre o cavaquinho brasileiro. Faz-se necessário navegar pelo contexto histórico-cultural e ponderar sobre o caráter de tradição e inovação com vistas a ampliar o entendimento da importância do cavaquinho na música brasileira.

Cavaco significa um pedaço, um estilhaço de madeira, uma conversa rápida sem assunto fixo, um jogo de botões ou moedas sobre uma tábua, um bolinho doce feito de trigo. "Dar cavaco" é dar satisfação, importância a alguém ou gostar muito de alguma coisa (LAROUSSE, 1970, p. 1463). "Cavaco chinês" no Nordeste do Brasil é uma referência ao biscoito conhecido no Sudeste como beijú paulista.

A respeito do instrumento musical propriamente dito, o cavaquinho é feito de madeira, e pertence à família das guitarras europeias, assim como o violão e a viola caipira, contudo, com dimensões bem reduzidas e com quatro cordas de aço ou de tripa. É um instrumento melódico e harmônico de vasta popularidade no Brasil, com som vibrante e agudo.

No livro, Instrumentos Musicais Populares Portugueses, Ernesto Veiga de Oliveira escreveu: 
O cavaquinho é um cordofone popular de pequenas dimensões, do tipo da viola de tampos chatos e, portanto, da família das guitarras européias, caixa de duplo bojo e pequeno enfraque, e de quatro cordas de tripa ou metálicas de "arame" (aço) - conforme os gostos, presas, nas formas tradicionais, em cima nas cravelhas e embaixo no cavalete colado no meio de bojo inferior do tampo. Além deste nome, encontramos ainda, para o mesmo instrumento ou outros com ele relacionados, as designações, de machinho, machin, machete, manchete ou marchete, braguinha ou braguinho, cavaco, etc. (OLIVEIRA, 1966, p. 139).

No Dicionário de Termos e Expressões da Música encontramos outra definição:

Instrumento de quatro cordas (ré-sol-si-ré) ${ }^{1}$ pinçadas, originou-se da tradição musical portuguesa, razão pela qual é também chamado como Braguinha (instrumento português típico do distrito de Braga). Seu formato lembra o de um pequeno violão, e costuma ser executado junto ao peito do músico com uma pequena palheta ${ }^{2}$ que serve para pinçar as cordas (DOURADO, 2004, p. $73)$.

Por ser de fácil portabilidade, devido ao seu tamanho reduzido, e por ter uma sonoridade viva, alegre e festiva, acabou conquistando outras terras, outros povos, ajudando a formar suas culturas.

Assim, esse pequeno pedaço de madeira, como o nome indica, foi sendo levado para a África (Cabo Verde, Guiné Bissau, Angola, Moçambique), Goa na Índia, Jacarta na Indonésia, Havaí e, finalmente, para a terra que adotou e consagrou o instrumento: o Brasil (CAZES, s/d, p. 2).

Nas terras brasileiras, o cavaquinho tem presença indispensável no samba e no choro. Também é encontrado, segundo as fontes às quais tive acesso, no baião, no frevo, no maxixe, na marcha e em manifestações folclóricas como o Bumba-meu-boi, Folia de Reis, Pastoris, Moçambique, Marujadas, Jongo, Congada, Carimbó e Cacuriá.

Além dos gêneros em que é usado, outro detalhe marca a diferença entre o cavaquinho no Brasil e em Portugal; a maneira de tocar. Enquanto aqui utilizamos a palheta para tanger as cordas, lá são utilizados os dedos da mão direita fazendo rasgueado (CAZES, s/d, p. 08).

Ângelo Corrêa, maestro do projeto Apanhei-te Cavaquinho, localizado em Cabo Frio RJ, emite sua própria versão sobre o cavaquinho brasileiro:

O modo de tocar cavaquinho brasileiro é uma mistura de Europa e África onde na mão esquerda, se faz os acordes tonais vindos do velho mundo e na mão direita pode-se sentir o rufar dos tambores africanos (CORRÊA, 2008).

\footnotetext{
${ }^{1}$ No meio musical dos cavaquinistas é comum se referir à afinação do cavaquinho da corda mais grave para a mais aguda.

2 "Espécie de unha de marfim, osso, plástico, com que se faz vibrar as cordas de certos instrumentos". (HOLLANDA, 2003)
} 
Segundo Henrique Cazes, a presença do cavaquinho no Brasil é marcada pela participação de grandes instrumentistas que cooperaram na evolução desse instrumento: Nelson Alves (1895-1960), que tocou com Chiquinha Gonzaga, foi um dos fundadores do grupo musical Os Oito Batutas e compôs os choros Mistura e Manda e Nem Ela... Nem Eu; Canhoto (1908-1987), que tocou com Benedito Lacerda e foi exímio acompanhador de cavaquinho; Garoto (1915-1955), virtuoso das cordas, que acompanhou Carmen Miranda e nos deixou composições como Duas Contas e Sinal dos Tempos (CAZES, s/d, p. 08).

O mais célebre solista de cavaquinho foi o carioca Waldir Azevedo (1923-1980), que elevou seu instrumento à categoria de concertista. Antes de Waldir, o cavaquinho era mais usado como instrumento acompanhante. Todos os cavaquinistas, sejam contemporâneos a Waldir Azevedo ou de gerações posteriores, foram influenciados por ele.

O Brasil tornou-se um caldeirão cultural devido à mistura das raças que formaram o nosso povo. Essa miscigenação influenciou todas as artes e a música não foi exceção. $\mathrm{O}$ cavaquinho, ou melhor, os cavaquinistas também receberam, e recebem constantemente, essa bagagem cultural universal que não para de chegar de todas as partes do mundo, trazendo as mais diversas influências. Portanto, a inovação, no modo de tocar um instrumento, sobrevém a partir de um momento de ousadia em que o músico começa a experimentar e misturar culturas.

Nos dias atuais, o cavaquinho brasileiro está muito bem representado por excelentes músicos como Alceu Maia, Andycavaco, Ana Claudia Cesar, Ana Rabelo, Arnaldinho do Cavaco, Assis da Paraíba, Auzier do Cavaco, Bruno Calmeto, Carlinhos do Cavaco, Carrapa do Cavaquinho, Chico de Assis, Dudu Braga, Eduardo Sant'Anna, Ely do Cavaco, Evandro Barcellos, Henrique Cases, Iuri Gules, Jaime Vignoli, João Paulo Albertim, Jorginho Gomes, Júnior do Cavaco, Júnior Fernandes, Léo Benon, Lucas Lima, Lincoln de Lima, Luciana Rabello, Luciano do Cavaco, Márcio Almeida Hulk, Márcio Marinho, Mariana Sardinha, Matheus Gomes, Matheus Donato, Mauro Diniz, Messias Brito, Nelson Latif, Nelsinho Serra, Nilze Carvalho, Paulinho do Cavaco, Paulinho da Viola, Pedro Cantalice, Pedro Molusco, Pedro Vasconcellos, Roberto Barbosa (Canhotinho), Ronaldinho do Cavaquinho, Sérgio Prata, Siqueira do Cavaco, Tayro Feitoza, Toco Preto, Valério Xavier (Valerinho), Valmar Amorim, Vinícius Juliano, Warley Henrique, Wellington Monteiro, Xixa e Zé Canela, entre outros. Com tantos cavaquinistas de alto nível que temos no Brasil, é difícil mencionar todos eles. Por isso peço desculpas se esqueci de citar alguém. 
No que se refere à transmissão de conhecimentos, além do modo empírico, que ocorre nas práticas musicais dos diversos gêneros onde o cavaquinho está presente, têm contribuído para a divulgação e o desenvolvimento do cavaquinho, a Escola de Choro Raphael Rabello, em Brasília, sob a direção de Reco do Bandolim; a Escola Portátil de Música, no Rio de Janeiro, com Luciana Rabello; o Projeto Apanhei-te Cavaquinho, em Cabo Frio, sob a batuta do Maestro Ângelo Corrêa (Budega); o Projeto Cultural Waldir Azevedo, fundado e dirigido pelo professor Dudu Oliveira em Brasília; o curso de cavaquinho do Conservatório de Música de Pernambuco, fundado por Marco César de Oliveira Brito; o curso de Bacharel em Cavaquinho na UFRJ, com o professor Henrique Cazes e o curso de cavaquinho da Escola de Música de Brasília, criado pelo autor deste trabalho.

Recentemente, com relação à organologia, três variações de forma do cavaquinho brasileiro ganharam adeptos: a guitarra baiana, um cavaquinho elétrico de corpo maciço, com afinação de bandolim ${ }^{3}$ e forma de guitarra, utilizado como instrumento solista nos trios elétricos; o banjo-cavaco ${ }^{4}$, com seu alto volume de som, usado no estilo musical pagode; e o cavaquinho de cinco cordas, que estava esquecido e volta a ser utilizado com as afinações solré-sol-si-ré e lá-ré-sol-si-ré, respectivamente as mesmas afinações da viola de arame da Ilha da Madeira e da viola da terra dos Açores. Existem ainda no Brasil outros dois modelos de cavaquinho que estão gradativamente entrando em desuso. Um deles é o cavaquinho modelo Paulistinha, com a caixa acústica bem menor, e o outro é o modelo Canhoto que tem reduzida somente a espessura (altura) do bojo. Ambos são mais utilizados como instrumento acompanhante.

Diante do exposto, este trabalho pretende contribuir para a ampliação do entendimento do que venham a ser o cavaquinho brasileiro tradicional e o cavaquinho brasileiro inovador. Consoante ao projeto de pesquisa "Tradição e Inovação na Música Brasileira Popular: o Choro e Suas Interfaces", sob a orientação da Professora Doutora Beatriz Duarte Pereira de Magalhães Castro da Universidade de Brasília, a pesquisa pode trazer significativa contribuição que examine a transposição de aspectos históricos, culturais, organológicos e das práticas musicais do cavaquinho para a cultura brasileira. Pretende-se, ainda, com esta pesquisa, disponibilizar aos músicos, estudantes de música, amantes da música brasileira,

\footnotetext{
${ }^{3} \mathrm{Na}$ guitarra baiana, geralmente, se usa a afinação de bandolim (sol, ré, la, mi), mas a afinação de cavaquinho também é usada.

${ }^{4}$ No banjo-cavaco, normalmente, se usa a afinação tradicional do cavaquinho (ré, sol, si, ré).
} 
entre outros, uma boa informação sobre este instrumento tão difundido e popularizado no Brasil.

Para cumprir nosso objetivo exploramos o tema a partir da seguinte estrutura:

No primeiro capítulo propomos um levantamento, no campo da organologia ${ }^{5}$, com a intenção de identificar os principais instrumentos que possam ser considerados como ancestrais do cavaquinho moderno e que tenham contribuído para a formação de sua configuração e sonoridade atuais. Exploramos alguns aspectos, como: o que é um cavaquinho? Como e onde surgiu o cavaquinho? Ainda abordamos a contribuição cultural do cavaquinho em vários países.

No segundo capítulo, investigamos o surgimento do estilo brasileiro de tocar o cavaquinho, influenciado pelas culturas que formaram o nosso povo, principalmente as culturas europeia e a africana. Damos ênfase aos gêneros musicais samba e choro, nos quais o cavaquinho se tornou instrumento indispensável devido ao seu acompanhamento rítmico-harmônico e fazemos uma breve abordagem no sentido de identificar a presença do cavaquinho em outras manifestações culturais brasileiras.

No terceiro e último capítulo, ponderamos sobre as constantes mudanças socioculturais que incidem sobre os cavaquinistas, possibilitando o surgimento de um novo estilo de tocar o instrumento. Para tanto, apontamos trabalhos musicais no cavaquinho que possuem características inovadoras, tanto no aspecto composicional como no aspecto interpretativo, e discutimos suas principais influências, buscando compreender como se desenrola o processo do surgimento do novo: a inovação.

\footnotetext{
${ }^{5}$ Estudo dos instrumentos musicais em termos de sua história, função social, design, construção e relação com a performance (GROVE, 2003).
} 


\section{CAPITULO 1 - CAVAQUINHO SEUS ANCESTRAIS, SUA ORIGEM, SUA TRAJETÓRIA ATÉ O BRASIL}

\section{1 - O cavaquinho e o sistema de Hornbostel \& Sachs}

Embora a denominação do instrumento "cavaquinho" não apareça na tabela de classificação do sistema Hornbostel e Sachs, julgo relevante localizá-lo neste sistema, integrando o grupo dos cordófonos compostos - alaúdes e guitarras de braço e caixa plana, devido às suas características, evidenciando semelhança não somente no aspecto construtivo como, também, no aspecto sonoro, especialmente em registros superagudos ${ }^{6}$ que nos faz notar timbre próximo ao de um cavaquinho.

Enquanto sistema de classificação de instrumentos musicais mais utilizado na atualidade por musicólogos e músicos, o dito sistema Hornbostel e Sachs, criado por Erich Moritz von Hornbostel e Curt Sachs, constitui "sistema [baseado] em princípios físicos e acústicos que regem o modo como os instrumentos produzem o som" (HENRIQUE, 2006, p. 15). Seus criadores se inspiraram em dois trabalhos: o primeiro, o extenso catálogo de instrumentos musicais elaborado por Victor Charles Mahillon enquanto trabalhava como conservador do Museu Instrumental de Bruxelas; o segundo, a classificação decimal de Melvin Dewey destinada à catalogação de fontes bibliográficas em bibliotecas (idem, p. 14$15)$.

Esse sistema abarca instrumentos independentemente de suas origens culturais no mundo, e foi dividido em quatro categorias as quais, posteriormente, com o surgimento dos instrumentos elétricos, foram expandidas a cinco:

1. Instrumentos idiofônicos: $\mathrm{O}$ som é produzido pela própria vibração do corpo do instrumento ou por alguma de suas partes. São eles quase todos os instrumentos de percussão como agogô, caxixí, maracás;

2. Instrumentos membranofônicos: São aqueles cujo som é emitido pela vibração de uma membrana esticada. Todos os tambores fazem parte desse grupo;

3. Instrumentos cordofônicos: O som é produzido por uma ou mais cordas tensionadas, suportadas por dois pontos fixos. Fazem parte desse grupo o

\footnotetext{
${ }^{6}$ Região do instrumento que emite som muito agudo, a partir do décimo segundo traste.
} 
violino, a viola, o violão, o contrabaixo, o bandolim, e também o nosso objeto de pesquisa, o cavaquinho;

4. Instrumentos aerofônicos: A força do ar, do vento, provoca a emissão sonora. Todos os instrumentos de sopro compõem esse grupo. Exemplo: flauta, flautim, trompete, trombone, bombardino, tuba, saxofone, clarinete, oboé e fagote;

5. Instrumentos eletrofônicos: Nessa categoria de instrumentos o som é produzido por meio eletrônico. Podemos citar o sintetizador.

Para descrição plena das características construtivas de um instrumento no sistema Hornbostel e Sachs ${ }^{7}$ é necessário acompanhar as suas várias ramificações descritivas. No caso dos cordófonos, que são representados pelo número (3), estes são divididos em: cordófonos simples (31) com suporte de corda único, ou suporte com ressonador removível; e cordófonos compostos (32), que possuem um suporte de cordas e um ressonador organicamente unidos que não podem ser separados sem destruir o instrumento.

Segundo a tabela a seguir, por meio dessas ramificações ou subdivisões, observa-se que os cordófonos compostos (32) são divididos em três tipos, de acordo com o modo como as cordas se posicionam em relação à caixa de ressonância, que podem ser do tipo: alaúdes (321), harpas (322), e harpas-alaúdes (323).

O tipo alaúde (321) é posteriormente dividido em três subcategorias, interessando-nos a dos alaúdes de braço (321.3) cuja característica é possuir corda passando por um braço plano. Esta por sua vez subdivide-se em duas outras subcategorias, interessando-nos a categoria dos alaúdes com braço conectado ao corpo (como um pescoço) (321.32), e por fim, na categoria dos alaúdes e guitarras com braço e caixa de ressonância com o fundo plano (321.322). A tabela a seguir nos permite visualizar estas subdivisões dos cordófonos compostos, colocando o cavaquinho, do ponto de vista de suas características construtivas no mesmo grupo do violino, da viola e do violão.

\footnotetext{
${ }^{7}$ Disponível em: http://learningobjects.wesleyan.edu/vim//svh.html. Acesso em: 20/04/2015.
} 
Tabela 1 - Classificação Hornbostel \& Sachs seção Cordófonos (3) ${ }^{8}$

\begin{tabular}{|c|c|c|c|}
\hline 32 & $\begin{array}{l}\text { Cordofones } \\
\text { Compostos }\end{array}$ & $\begin{array}{lll}\mathrm{O} \text { braço e a caixa de ressonância } & \text { são } \\
\text { organicamente unidos e não podem } & \text { ser } \\
\text { separados sem destruir o instrumento } & \\
\end{array}$ & \\
\hline 321 & Alaúdes & $\begin{array}{l}\text { O plano das cordas corre paralelo com o plano } \\
\text { da caixa }\end{array}$ & \\
\hline 321.1 & $\begin{array}{l}\text { Alaúdes com arco } \\
\text { (pluriarco) }\end{array}$ & $\begin{array}{l}\mathrm{O} \text { braço e a caixa de ressonância são } \\
\text { organicamente unidos, mas podem ser separados } \\
\text { sem destruir o instrumento }\end{array}$ & $\begin{array}{l}\text { Instrumentos } \\
\text { africanos: } \\
\text { akam, kalanga } \\
\text { e wambi }\end{array}$ \\
\hline 321.2 & Alaúde ou Liras & $\begin{array}{l}\text { As cordas são conectadas a uma superfície curva } \\
\text { como caixa de ressonância e a uma barra } \\
\text { transversal que é sustentada por dois braços }\end{array}$ & \\
\hline 321.21 & Liras de caixa & $\begin{array}{l}\text { Uma caixa natural ou esculpida serve como } \\
\text { ressonador }\end{array}$ & Lira Africana \\
\hline 321.22 & Liras de caixa & $\begin{array}{l}\text { Uma caixa construída em madeira serve como } \\
\text { ressonador }\end{array}$ & Cithara \\
\hline 321.3 & Alaúdes de braço & $\begin{array}{l}\text { A corda passa por um braço plano. Braços de } \\
\text { apoio como, por exemplo, o da Vina Prasarini } \\
\text { indiana são desconsiderados, como também nos } \\
\text { alaúdes distribuídos em vários braços. Como a } \\
\text { harpa-lira e guitarras-liras, em que a caixa é } \\
\text { meramente ornamental }\end{array}$ & \\
\hline 321.31 & $\begin{array}{l}\text { Alaúdes com braço } \\
\text { acoplado }\end{array}$ & $\begin{array}{l}\text { O braço passa diretamente através da caixa de } \\
\text { ressonância }\end{array}$ & \\
\hline 321.311 & $\begin{array}{lrr}\begin{array}{l}\text { Alaúdes } \\
\text { com }\end{array} & \text { de } & \text { caixa } \\
\text { braço } & \\
\text { acoplado } & & \\
\end{array}$ & $\begin{array}{l}\text { A caixa de ressonância é constituída por um } \\
\text { bojo natural ou esculpido }\end{array}$ & $\begin{array}{l}\text { Persia, India, } \\
\text { Indonesia }\end{array}$ \\
\hline 321.312 & $\begin{array}{l}\text { Alaúdes e guitarras } \\
\text { com braço e caixa }\end{array}$ & A caixa de ressonância é construída em madeira & Rebab egípcio \\
\hline 321.313 & $\begin{array}{l}\text { Alaúdes de tubo e } \\
\text { braço }\end{array}$ & $\begin{array}{l}\text { O braço passa diretamente através das paredes } \\
\text { de um tubo }\end{array}$ & $\begin{array}{l}\text { China, } \\
\text { Indochina }\end{array}$ \\
\hline 321.32 & Alaúde com braço & $\begin{array}{l}\text { O braço é conectado ou esculpido a partir da } \\
\text { caixa de ressonância (como um pescoço) }\end{array}$ & \\
\hline 321.321 & $\begin{array}{l}\text { Alaúdes com caixa } \\
\text { arredondada }\end{array}$ & & $\begin{array}{l}\text { Mandolino, } \\
\text { Theorba, } \\
\text { Balalaika }\end{array}$ \\
\hline 321.322 & $\begin{array}{l}\text { Alaúdes e guitarras } \\
\text { de braço e caixa de } \\
\text { fundo plano }\end{array}$ & $\begin{array}{l}\text { Alaúdes cujo corpo possui formato levemente } \\
\text { abombado e caixa de fundo plano }\end{array}$ & $\begin{array}{l}\text { Violino, Viola } \\
\text { e Violão }\end{array}$ \\
\hline 322 & Harpas & $\begin{array}{l}\text { O plano das cordas está em ângulo reto com o } \\
\text { plano da caixa de ressonância, de onde partem as } \\
\text { cordas com suas extremidades se conectando ao } \\
\text { braço }\end{array}$ & \\
\hline 322.1 & Harpas abertas & A Harpa não possui um pilar & \\
\hline 322.11 & Harpas arqueadas & $\begin{array}{l}\text { O braço possui curvatura distante da caixa de } \\
\text { ressonância }\end{array}$ & Burma e África \\
\hline 322.12 & Harpas angulares & $\begin{array}{l}\text { O braço faz um ângulo agudo com a caixa de } \\
\text { ressonância }\end{array}$ & $\begin{array}{l}\text { Antiga Assíria, } \\
\text { Antigo Egito e } \\
\text { Antiga Coréia } \\
\end{array}$ \\
\hline 322.2 & Harpas de quadro & Harpa possui um & \\
\hline
\end{tabular}

\footnotetext{
${ }^{8}$ Disponível em: http://repositorio.unb.br/bitstream/10482/10040/1/2011_JorgeAntonioCardosoMoura.pdf
} Acesso em: 25/08/ 2012. 


\begin{tabular}{|c|c|c|c|}
\hline 322.21 & $\begin{array}{l}\text { Sem dispositivo } \\
\text { para afinação }\end{array}$ & & $\begin{array}{ll}\text { Todas } & \text { as } \\
\text { Harpas } & \\
\text { medievais } & \end{array}$ \\
\hline 322.211 & $\begin{array}{l}\text { Harpas diatônicas } \\
\text { de quadro }\end{array}$ & & \\
\hline 322.212 & $\begin{array}{l}\text { Harpas cromáticas } \\
\text { de quadro }\end{array}$ & & \\
\hline 322.212 .1 & $\begin{array}{l}\text { Com as cordas em } \\
\text { um plano }\end{array}$ & & $\begin{array}{l}\text { A maioria das } \\
\text { Harpas } \\
\text { Cromáticas } \\
\text { antigas }\end{array}$ \\
\hline 322.212 .2 & $\begin{array}{l}\text { Com as cordas que } \\
\text { se cruzam entre si }\end{array}$ & & $\begin{array}{l}\text { A Harpa } \\
\text { Cromática } \\
\text { Lyon }\end{array}$ \\
\hline 322.22 & $\begin{array}{l}\text { Com dispositivo } \\
\text { para afinação }\end{array}$ & $\begin{array}{l}\text { As cordas poderão ser reguladas por uma ação } \\
\text { mecânica }\end{array}$ & \\
\hline 322.221 & Com ação manual & $\begin{array}{l}\text { A afinação poderá ser realizada por alavancadas } \\
\text { manuais }\end{array}$ & $\begin{array}{l}\text { Harpa gancho, } \\
\text { Harpa dital, } \\
\text { Harpinella }\end{array}$ \\
\hline 322.222 & $\begin{array}{l}\text { Com afinação de } \\
\text { pedal }\end{array}$ & O ajuste de afinação poderá ser feito por pedais & \\
\hline 323 & Harpas Alaúdes & $\begin{array}{l}\text { O plano das cordas está em ângulo reto com o } \\
\text { plano da caixa de ressonância, uma linha une as } \\
\text { extremidades inferiores das cordas } \\
\text { perpendiculares ao braço. Ponte dentada }\end{array}$ & Kasso africano \\
\hline
\end{tabular}

Fonte: Jorge Antônio Cardoso Moura (adaptada pelo autor)

Na tabela a seguir, apresentamos ainda a classificação pelo modo como os instrumentos são tangidos:

Tabela 2 - Legenda da Classificação SVH (Hornbostel \& Sachs), seção Cordófonos (3) ${ }^{9}$

\begin{tabular}{ll}
\hline 4. & tocada por martelos ou batedores \\
\hline 5. & tocada com os dedos \\
\hline 6. & tocada com um plectro ou palheta \\
\hline 7. & tocada com artefato curvo \\
\hline 7.1. & tocada com um arco \\
\hline 7.2. & tocada por uma roda \\
\hline 7.3. & tocada por uma faixa de fita \\
\hline 8. & tocada com um teclado \\
\hline 9. & tocada por acionamento mecânico
\end{tabular}

Fonte: Jorge Antônio Cardoso Moura (adaptada pelo autor)

\footnotetext{
${ }^{9}$ Disponível em: http://repositorio.unb.br/bitstream/10482/10040/1/2011_JorgeAntonioCardosoMoura.pdf Acesso em: 25/08/ 2012.
} 
Observando e estudando as duas tabelas expostas anteriormente, podemos concluir que o cavaquinho é um cordófono composto (32), do grupo dos alaúdes cujo plano das cordas corre paralelo ao plano da caixa (321), pertencendo ao subtipo de alaúdes de braço cujas cordas perpassam por um braço plano (321.3), com o braço conectado ou esculpido a partir da caixa de ressonância, como um pescoço (321.32) e, por fim, ao grupo de alaúdes e guitarras de braço e caixa de fundo plano (321.322).

No que se refere ao modo de tanger as cordas, verificamos na tabela 2 que o cavaquinho brasileiro, por ser tocado com palheta ou plectro, pertence à categoria número 6 . Portanto, a identificação numérica do cavaquinho brasileiro, segundo o sistema de classificação de instrumentos musicais Hornbostel e Sachs, conforme exposto nas tabelas 1 e 2, receberia a classificação 321.322-6 (quando executado com plectro) e 321.322-5 (quando tocado com os dedos no caso do cavaquinho português).

De forma a ilustrar o processo de classificação acima descrito, segue a seguir um organograma contendo sua derivação e numeração correspondente: 


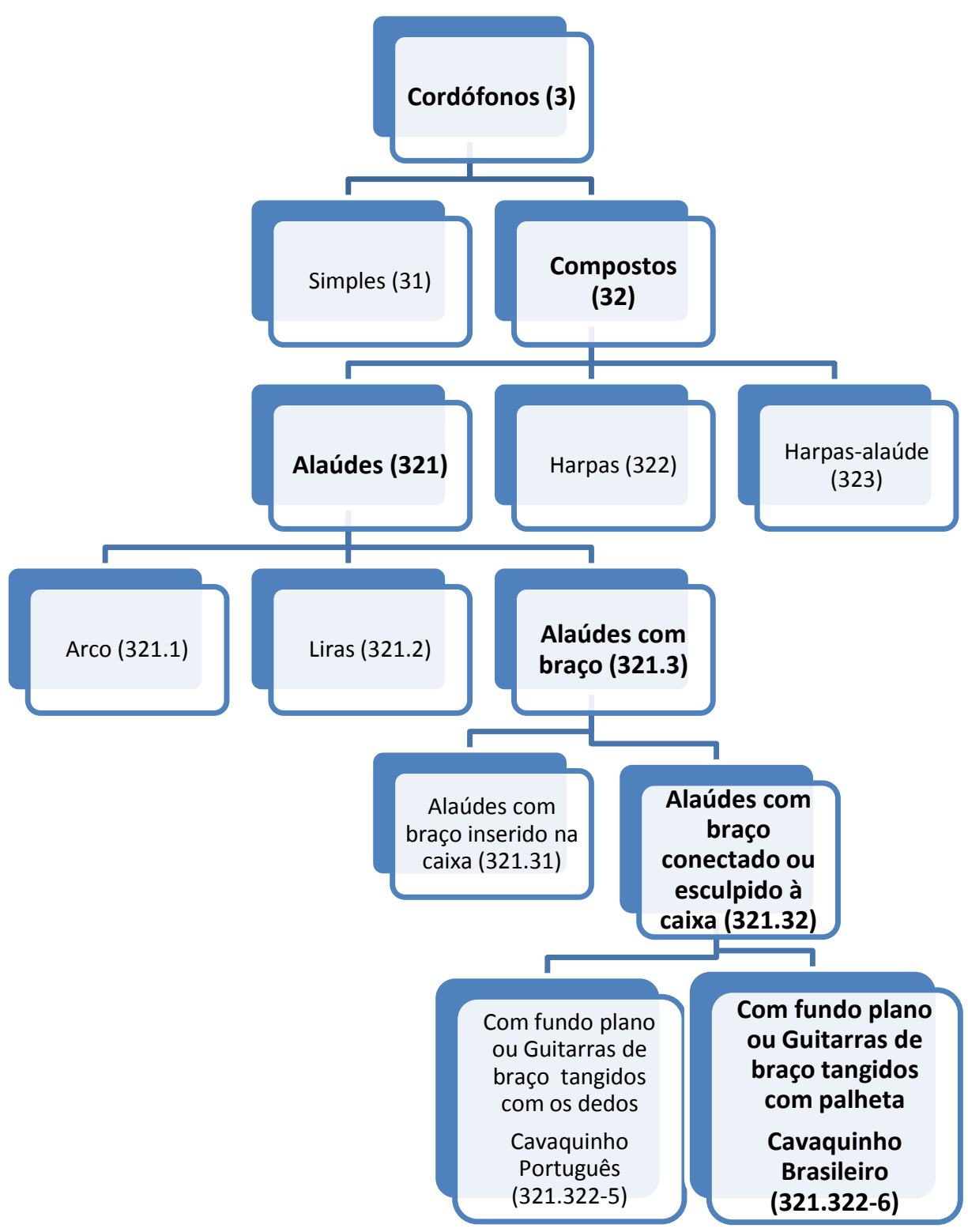

Figura 1- Classificação SHV (Hornbostel \& Sachs), seção Cordófonos (3)

Em suma, pela similitude dos seus aspectos construtivos, o resultado deste processo de classificação aponta o alaúde como "matriz" construtiva vindo a reunir num mesmo subgrupo violinos e violas, assim como o violão e o cavaquinho, por possuírem características construtivas semelhantes e ressaltando o caráter de transformação e adaptação da sua morfologia a contextos culturais diversificados ao longo de largo período de tempo como veremos mais adiante. 


\section{2 - A palheta ou plectro}

Considero relevante fazer aqui alguns esclarecimentos sobre a palheta ou plectro, que segundo consta no Dicionário Aurélio da Língua Portuguesa: "É uma espécie de unha de marfim, osso ou plástico com que se faz vibrar as cordas de certos instrumentos" (HOLLANDA, 2003). O bandolinista e pesquisador Paulo Sá nos fala, em seu artigo Palheta e Articulação no Bandolim: Uma Contextualização para Compositores, Arranjadores e Instrumentistas, que durante a Idade Média o uso da palheta foi comum na família das guitarras e dos alaúdes. Sá revela que hoje o uso da palheta pode ser observado na execução de instrumentos orientais, tais como o biwa, tocado no Japão, e o samisen, tocado na China e no Japão. Na Grécia Antiga, o uso deste utensílio era bastante comum e, segundo consta no The New Grove Dictionary of Music and Musicians, era feito de madeira, marfim, osso, casco de tartaruga, pena ou garra de águia, sendo chamada de pecten ou plectron (SÁ, 2012, p. 66$67)$.

Cazes escreveu, no livro Escola Moderna do Cavaquinho, que a escolha da palheta é uma questão muito pessoal e observa que uma palheta mole é mais barulhenta e não é boa para solos, enquanto uma palheta dura serve tanto para solos como para centro (acompanhamento harmônico). Em outros detalhes, o cavaquinista informa que quanto menor a palheta, menos ruído causa e, sem maiores explicações, fala que a palheta de plástico escuro tem uma resposta mais positiva que a colorida. Por fim, completa dizendo que a palheta de casco de tartaruga não quebra, somente desgasta e que, qualquer que seja o material, o importante é que a superfície de contato esteja polida, para evitar ruídos (CAZES, s/d, p. 11).

A palheta de casco de tartaruga está praticamente em desuso por se tratar de crime ambiental. Faz muitos anos que não a vejo, nem ouço falar de algum músico que a possua. Já tive a oportunidade de experimentar uma dessas e, realmente, facilita o tocar. Por outro lado, tenho usado algumas palhetas importadas que produzem uma resposta sonora muito satisfatória.

Com o advento da indústria do plástico e com a crescente campanha de proteção aos animais, a utilização de palhetas feitas de casco de tartaruga tornou-se cada vez menos comum. Sendo assim, a indústria de palhetas encontrou um nicho muito grande no mercado da guitarra elétrica, atendendo também aos bandolinistas (cavaquinistas e banjistas). No entanto, dentro e fora do Brasil, hoje a preferência continua sendo o casco de tartaruga, pois proporciona uma qualidade melhor de som. Além disso, as palhetas de 
plástico gastam mais rapidamente. Outros tipos de palheta têm sido testados com caráter experimental. Materiais como feltro, chifre, osso, ágata, concha e cristal são utilizados na busca de novos timbres e efeitos, produzindo diferentes nuances (SÁ, 2012, p. 69).

Neste trabalho o leitor encontrará o termo palhetada, que é uma conjugação do verbo palhetar, derivado do substantivo palheta. Sobre o assunto, Paulo Sá comenta: "Ao adotarmos aqui o termo palheta, adotamos também o verbo palhetar, que significa as articulações da palheta sobre as cordas, envolvendo a mão, o punho, o antebraço e os dedos que seguram a palheta" (SÁ, 2012, p. 66).

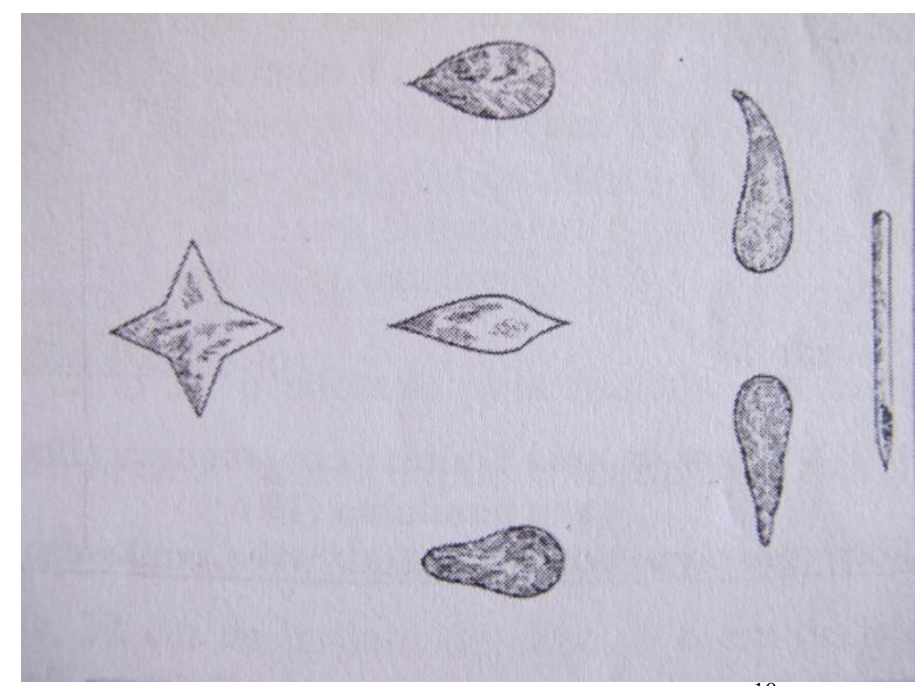

Figura 2 - Vários Formatos de Palhetas ${ }^{10}$

\section{3 - Os ancestrais: alaúde, tanbur, cítala e gittern}

A fim de dar ao leitor uma noção introdutória sobre o alaúde e outros instrumentos que deixaram traços organológicos na família das guitarras europeias, da qual faz parte o cavaquinho, dedicaremos a eles algumas considerações.

${ }^{10}$ (PISANI, 1996 apud MOURA, 2011, p. 43). 


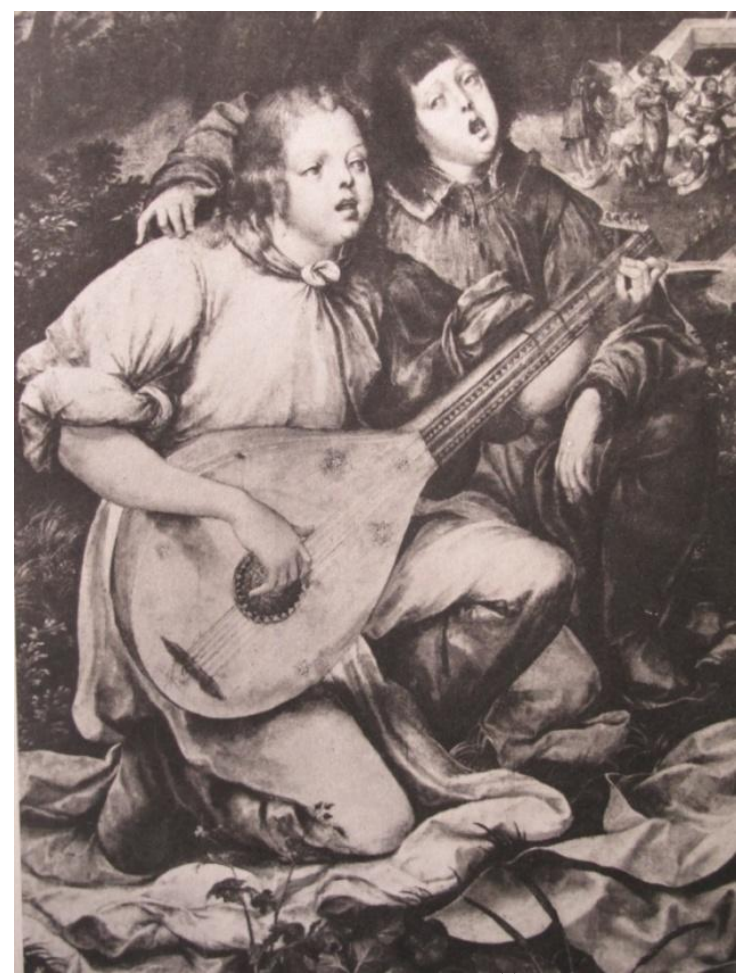

Figura 3 - Alaúde

Segundo consta no Diccionario de la Musica, o alaúde é de origem oriental e provavelmente foi levado para a Europa na época das Cruzadas. Seu nome em árabe é al-ud, e em latim medieval, era chamado testudo como referência ao parentesco remoto com a lyra grega. Acredita-se que os instrumentos de cordas do gênero do alaúde já existiam na antiga civilização egípcia e na civilização dos assírios (CORTE \& GATTI, 1950, p. 267).

Pensa-se que a guitarra (o violão) possa ter a sua origem em alaúdes do antigo Egito, por terem sido encontrados em escavações instrumentos de caixa de ressonância cintada com um braço longo e estreito e vestígios da existência de três ou quatro cordas e alguns trastes (HENRIQUE, 2006, p. 157).

O pesquisador Roland de Candé, em seu livro História Universal de la Musica, confirma a presença, no antigo Egito, do alaúde ou pandora. De origem semita ${ }^{12}$, também era o único instrumento com braço utilizado no Egito. Possuía três ou quatro cordas e era tocado com plectro. Não se conhece seu nome no egípcio antigo (CANDÉ, 1981, p. 60). Sobre o alaúde, o mesmo autor acrescenta:

\footnotetext{
${ }^{11}$ Imagem número 112 do livro Instrumentos Musicais Populares Portugueses (OLIVEIRA, 1966). Pormenor do quadro A Virgem com o Menino, com dois anjos músicos, um cantor e o outro alaudista. Este quadro se encontra no Museu de Arte Antiga de Lisboa e foi pintado por Gregório Lopes, no século XVI.

121 Indivíduo pertencente a uma raça que se diz descendente de Sem: personagem bíblica e um dos filhos de Noé. 2 Judeu. Disponível em <http://www.dicionariodoaurelio.com/semita>. Acesso em: 14/04/2015.
} 
$U d$ : derivado do antigo barbat persa, hoje desaparecido, é o instrumento de cordas pinçadas, mais difundido nos países árabes. No século XIII foi introduzido na Europa onde recebeu a denominação de alaúde (al+ud) (CANDÉ, 1981, p. 161).

O alaúde começou a difundir-se com o surgimento da arte gótica, por volta dos séculos XI e XII. Na sua configuração original tinha caixa de ressonância, ou melhor, o bojo, com formato convexo, construída com tiras de madeira. O tampo era plano com uma rosácea, artisticamente elaborada, que servia tanto como abertura para a saída de som como para ornamentar o instrumento. Preso à caixa acústica se estendia o braço, cuja extremidade era dobrada para trás em um ângulo reto, sobre o qual se esticavam as cordas em número que variavam de quatro a cinco pares. No começo do século $\mathrm{XV}$, o alaúde apresentava seis pares de cordas, mas ao final do mesmo século seu tamanho foi aumentado e chegou a apresentar 10 ou 11 pares de cordas (CORTE \& GATTI, 1950, p. 267).

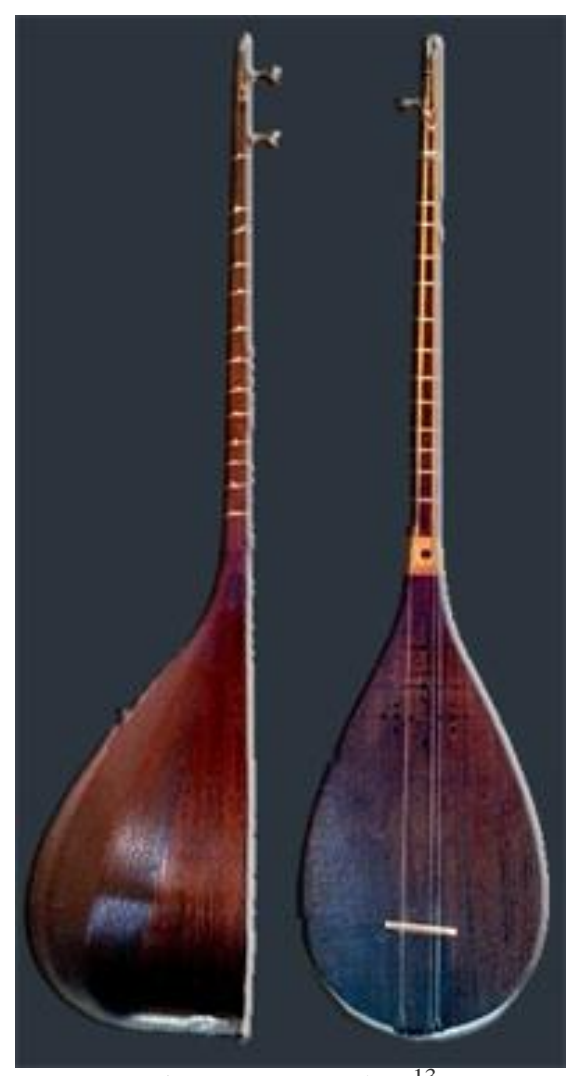

Figura 4 - Tanbur ${ }^{13}$

Como uma variação do alaúde surge o tanbur ou saz (figura 4), um alaúde de braço comprido utilizado sobre tudo na Turquia (CANDÉ, 1981, p. 161). Segundo o pesquisador

\footnotetext{
${ }^{13}$ Disponível em: <http://toosfoundation.com/resources-musical-instruments>. Acesso em: 14/04/2015.
} 
Jorge Cardoso Moura, o tanbur é originário da Pérsia e possui três tamanhos, sendo o mais popular o baglama, de menor porte. O fundo da caixa de ressonância é abaulado, seu braço possui trastes e o cavalete é móvel, apoiado no tampo superior (MOURA, 2011, p. 28).

A Idade Média se caracterizou como sendo um período de várias experimentações no que se refere a construções de instrumentos musicais. Assim, no século XII surge a cítola, descendente do alaúde, porém com o fundo do bojo plano. Tal característica construtiva é encontrada no cavaquinho e em outros instrumentos de fundo plano utilizados no Brasil, como o violão e o bandolim (MOURA, 2011, p. 31). Segundo consta no livro Pelo Mundo do Som: Dicionário Musical de Frei Pedro Sinzig, a cítola também recebeu as seguintes denominações: citula, cítara, citra, cistro, cistre; na França sistre e sistro e, na Alemanha, guitarra (SINZIG, 1959, p. 161).

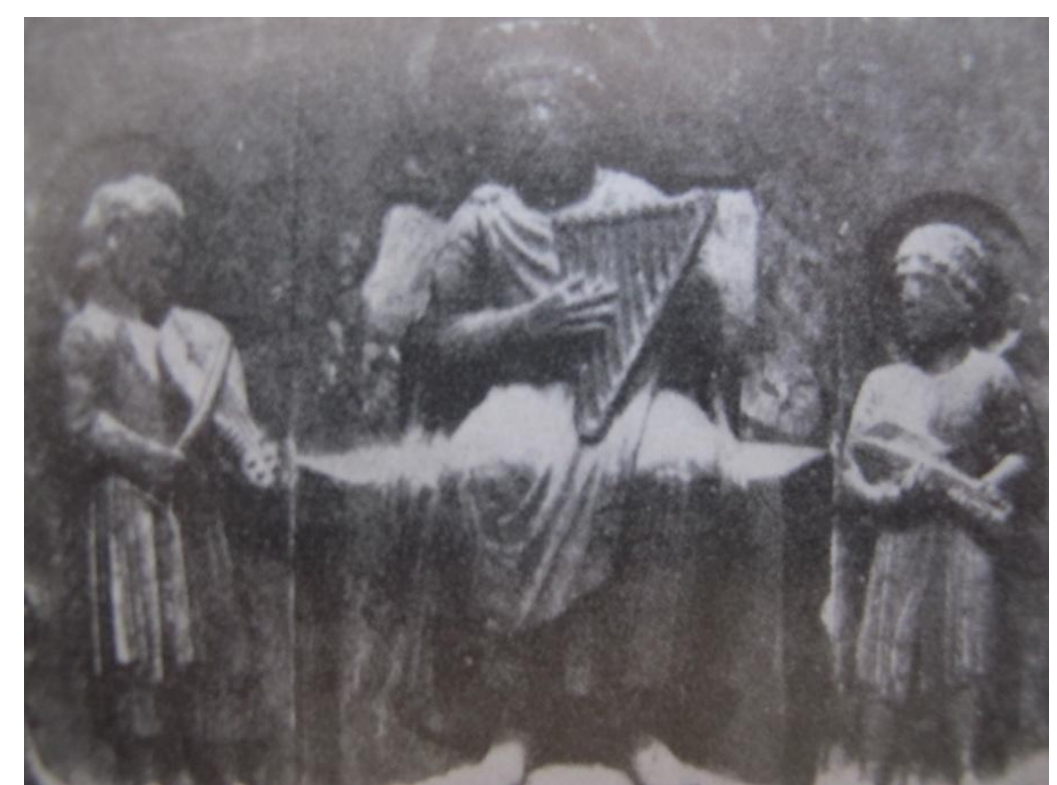

Figura 5 - Escultura de Benedetto Antelami, em uma porta do Batistério de Parma, séc.XII. ${ }^{14}$

Na figura acima temos ao centro o Rei David tocando o saltério, instrumento de cordas em forma triangular que estava em voga na Idade Média, à esquerda um tocador de rabel, outro instrumento medieval, da família do violino, e à direita um músico tocando o cistro ou cítola (BRENET, 1981, p. XXI).

$\mathrm{Na}$ figura a seguir uma das versões da cítola, com quatro cordas, que se assemelha a um cavaquinho.

\footnotetext{
${ }^{14}$ Imagem extraída do Diccionario de la Música de Michel Brenet, 1981, p. XXI.
} 


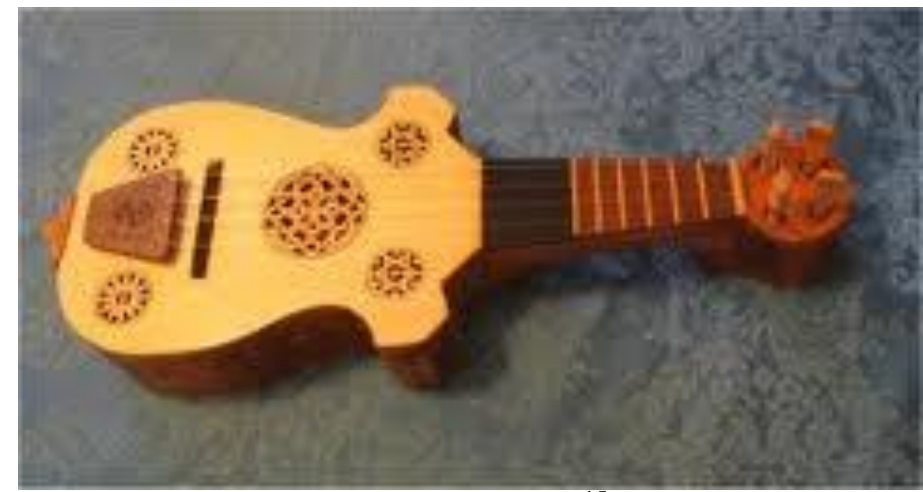

Figura 6 - Cítola ${ }^{15}$

Outro instrumento que pode ser considerado um dos antecessores das guitarras modernas é o gittern, que também aparece em imagens representativas de instrumentos da Idade Média e, muitas vezes, é confundido com a própria cítola.

O gittern se originou nos países árabes em torno do século XIII e foi posteriormente para Europa, onde recebeu várias denominacões: guisterne, guitarre, guiterne, guiterre, quinterne, quitaire, quitarre na França; quinterne na Alemanha, guitarra na Espanha e chitarino na Itália. Era um instrumento pequeno e não tinha clara divisão entre o pescoço e o corpo. Seu encordoamento era composto de cordas duplas que variavam entre três e cinco pares. Seu formato frontal era piriforme (forma de pêra) e sua caixa de ressonância possuía fundo abaulado, como o alaúde (GROVE, 1980).

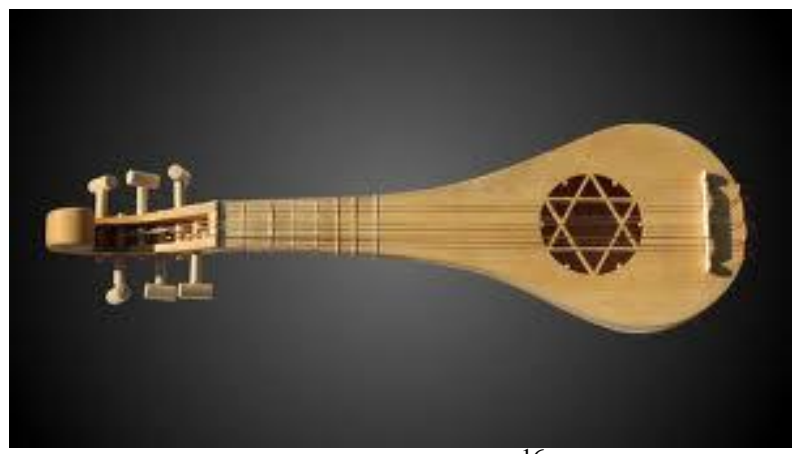

Figura 7 - Gittern ${ }^{16}$

O Dicionário de Música de, Alan Isaacs e Elizabeth Martin, traz a seguinte definição para guiterne:

15 Disponível em: <http://www.frantisekpavlik.estranky.cz/clanky/o-nastrojich/citola-_-the-citole-_-sytole-_cytiole-_-gytiolle.html>. Acesso em: 17/ 09/2013.

${ }^{16}$ Disponível em: <http://imgarcade.com/1/gittern-instrument/>. Acesso em: 10/03/2015. 
Forma medieval da guitarra em que o corpo e o braço eram talhados do mesmo bloco de madeira, com um orifício sob o ponto para o polegar do tocador. A guiterne tinha usualmente quatro pares de cordas de tripa afinadas em ré-sol-si-mi e era tocada com um plectro (ISAACS \& MARTIN, 1985, p. 160).

Segundo Jorge Cardoso Moura, é importante ressaltar que alguns dos instrumentos antigos, como o gittern e a cítola, que fazem parte do processo histórico que originou os instrumentos modernos, por muitas vezes, ao longo da história, tiveram seus nomes trocados. Isto significa que um determinado instrumento pode ter carregado nomenclaturas diversificadas e também que um mesmo nome pode ter sido usado para mais de um instrumento. "Assim, a caracterização das diferenças nos aspectos construtivos de cada modelo foi relevante para estabelecer relações entre nomenclaturas e classificações" (MOURA, 2011, p. 35).

\section{4 - A vihuela, a guitarra renascentista, a guitarra barroca, a guitarra romântica, o requinto}

Seguindo a cadeia de desenvolvimento que culminou na consolidação da configuração física atual do violão, do cavaquinho e da viola, sugerimos aqui uma breve abordagem exploratória, a fim de identificar os instrumentos que surgiram depois do alaúde com formatos característicos da família das guitarras europeias. Ricardo Louzao, em seu livro La Guitarra Mágica, ressalta as influências árabes e latinas nesse processo:

É necessário entender que na gestação do violão (e similares) intervieram duas forças culturais claras: por um lado a cultura árabe, da qual a vihuela e os demais instrumentos trazem características visuais como as rosetas e as tarrachas, e por outro lado a influência da cultura latina e do mundo cristão que, entre outras coisas, trouxeram a forma de oito aos instrumentos (LOUZAO, 2009, p. 22).

\subsection{1 - A Vihuela}

Instrumento espanhol da família do alaúde, porém com a caixa de ressonância em forma de oito, como o violão. De origem antiga, no século XIII, alcançou seu auge de popularidade no século XVI (CORTE \& GATTI, 1950, p. 523). 
A vihuela pode ser encontrada em diversos tamanhos e número de cordas que variam entre cinco e sete. Originalmente, o nome "viola" era usado para vários instrumentos de cordas, como: a vihuela de arco, que seria a viola da gamba ${ }^{17}$, com trastes e seis cordas; a vihuela de roda (viella), instrumento curioso com teclados sobre uma caixa acústica piriforme e uma manivela que girava uma roda, acionada por outra pessoa; e a vihuela de mano, hoje denominada vihuela (BRENET, 1981, p. 544-45).

Ricardo Louzao nos mostra sua versão a respeito do surgimento da vihuela e de seu número de cordas:

A vihuela surge, se desenvolve e desaparece no ciclo do ouro espanhol (séc. XVI). [...] Possui seis ordens de cordas (12 cordas; era comum o uso de uma só corda na primeira ordem). Há a possibilidade de terem existido vihuelas de cinco e de sete ordens (LOUZAO, 2009, p. 21).

Como podemos observar na figura abaixo, a vihuela, bem como o alaúde, tinha entre uma de suas características a presença de rosáceas e trastes.

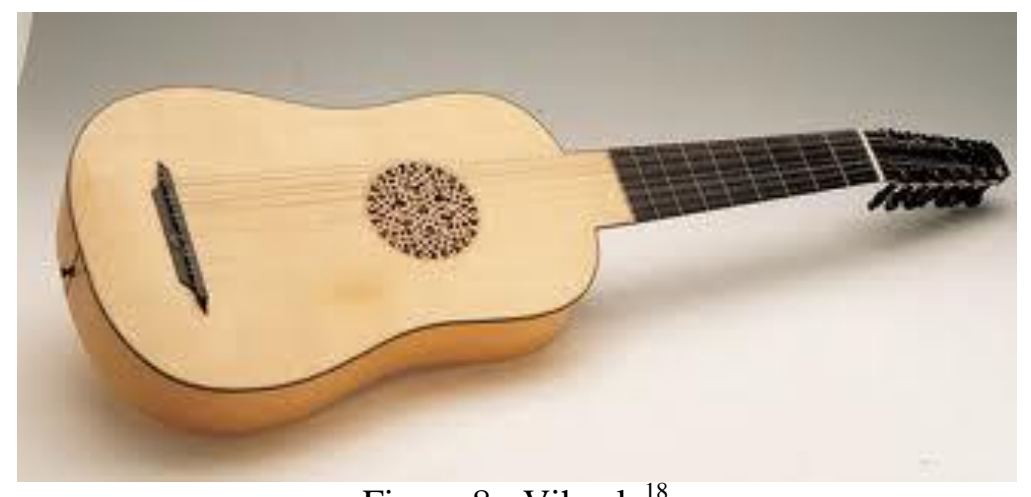

Figura 8 - Vihuela ${ }^{18}$

Segundo depoimento do Professor Nicolas de Souza Barros ${ }^{19}$, a vihuela nada mais é que um alaúde com o bojo em formato de oito. Por volta do século XV, os nobres espanhóis começaram a querer um instrumento diferente do alaúde para fazer parte dos concertos musicais nas cortes reais. Esse fato teria contribuído para o surgimento da vihuela (BARROS, 2012).

\footnotetext{
${ }^{17}$ Instrumento da família do violino, antecessor do violoncelo.

${ }^{18}$ Disponível em: http://www.musicaantigua.com/la-vihuela-esa-desconocida/ Acesso em: 10/ 03/ 2015.

${ }^{19}$ Nicolas de Souza Barros é professor da Universidade Federal do Estado do Rio de Janeiro (UNIRIO), Doutor em Música (UNIRIO - 2008) e um dos mais conceituados especialistas do país em instrumentos de cordas dedilhadas, tais como violões de seis e oito cordas, alaúdes diversos, vihuela e guitarra barroca. Disponível em: http://www2.unirio.br/unirio/cla/ivl/professores/nicolas-de-souza-barros. Acesso em: 16/09/2013. Depoimento sobre vihuela: https: //www.youtube.com/watch?v=41j2t4AmuUQ.
} 


\subsection{2 - A Guitarra Renascentista ${ }^{20}$}

É a guitarra do período do Renascimento (fins do séc. XIV e meados do séc. XVI). Esse instrumento, surgido na Espanha, pode ser chamado de uma forma popular de "avó" do violão, com suas dimensões reduzidas. Com cordas de tripa, a guitarra renascentista tem uma particularidade: a primeira corda única e as três restantes dispostas em pares em uma afinação de quarta, terça e quarta que é encontrada no violão moderno (BARROS, 2012). Essa afinação teria sido herdada do gittern, tipo de alaúde medieval de dimensões reduzidas, ao qual já fizemos referência nesse trabalho.

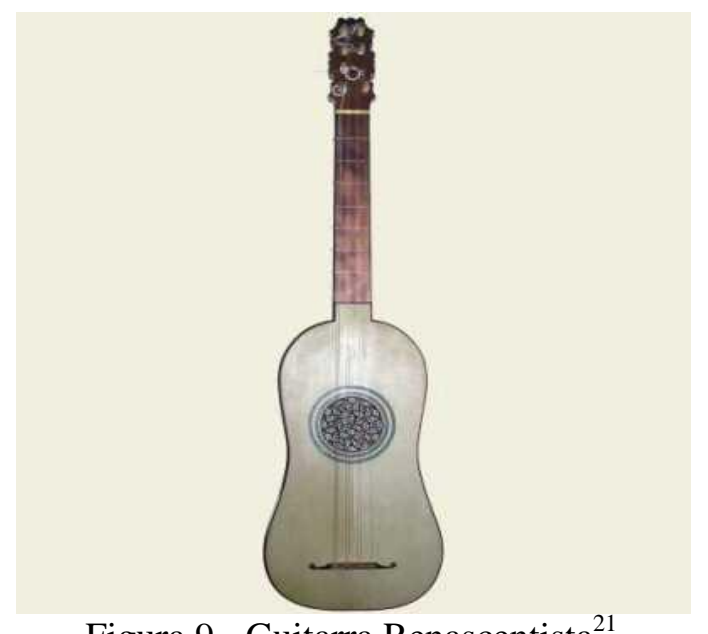

Figura 9 - Guitarra Renascentista ${ }^{21}$

Não eram muitos os que compunham para a guitarra renascentista, que era mais usada na música popular, no acompanhamento de cantores ou grupos musicais (BARROS, 2012). "Se pode dizer que a guitarra renascentista (na Espanha), era a irmã pobre da vihuela e seu uso era comum entre o povo" (LOUZAO, 2009, p. 22).

É importante que o leitor compreenda que os nomes que hoje são dados a estes instrumentos (guitarra barroca, renascentista, romântica, etc.) são produtos da nossa época, nosso costume de classificar; simplesmente estes instrumentos eram chamados guitarras (LOUZAO, 2009, p. 22).

\footnotetext{
${ }^{20}$ Dados sobre guitarra renascentista disponível em: www.youtube.com/watch?v=yKugdWLMQSA. Postado em: 08/05/2012. Acesso em: 17/09/2013.

${ }^{21}$ Disponível em: http://lahistoriadelaguitarr.blogspot.com.br/2013/03/la-guitarra-renacentista.html. Acesso em: 17/05/15.
} 


\subsection{3 - A Guitarra Barroca ${ }^{22}$}

A guitarra barroca, do período barroco (1600-1750), é outro ancestral do violão clássico moderno, com menores dimensões e, assim como a guitarra renascentista e a vihuela, possui as curvaturas de suas ilhargas menos acentuadas, como nos demonstram as fontes iconográficas.

Segundo Nicolas de Souza Barros, ao longo do século XVI o alaúde começou a ter muitas cordas, geralmente na região grave, e por isso se tornou um instrumento bastante complicado para tocar. Assim, a guitarra barroca, que pode ser o descendente direto da guitarra renascentista, tomou o seu lugar nas preferências dos nobres amadores. Era construída com cinco pares de cordas duplas, com a mesma afinação das cinco cordas de baixo do violão moderno e geralmente com poucas cordas graves, o que permite o uso da técnica chamada de campanela (pinçar as cordas, com os dedos indicador e polegar) na execução de escalas musicais. A guitarra barroca também é tocada com o uso do rasgueado (BARROS, 2012). Outra característica deste instrumento é o desenho do cavalete em formato de "bigode", como podemos observar na figura a seguir:

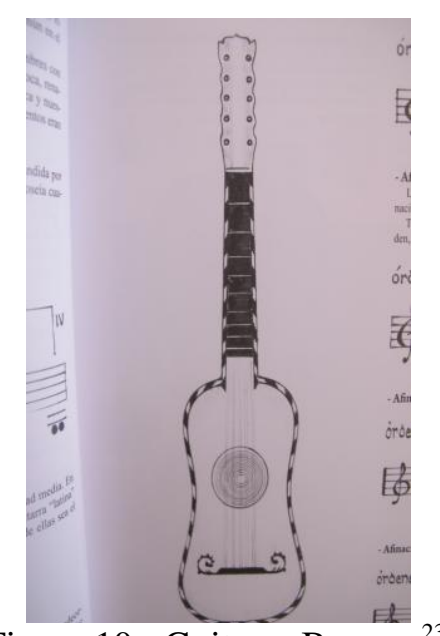

Figura 10 - Guitarra Barroca ${ }^{23}$

Ricardo Louzao aponta para o uso de uma corda simples na primeira ordem e fala sobre as técnicas usadas na execução da guitarra barroca: "Muito comum neste instrumento, é

\footnotetext{
${ }^{22}$ Informações sobre a guitarra barroca colhidas no depoimento do Professor Nicolas de Souza Barros, disponíveis em:<https://www.youtube.com/watch?v=DPrYTIR9R40>. Acesso em: 17/09/2013.

${ }^{23}$ Imagem extraída do livro La Guitarra Mágica (LOUZAO, 2009, p.23).
} 
o uso de três técnicas: de solo, campanela e rasgueado. Os ataques (como antecessores dos usados na guitarra flamenca) também seriam usados em parte do repertório" (LOUZAO, 2009, p. 23-24).

\subsection{4 - A Guitarra Romântica ${ }^{24}$}

Ao longo do século XVIII a guitarra barroca sofreu algumas modificações, dando origem à guitarra romântica. Um baixo foi acrescido e, assim, as cinco cordas duplas viraram seis cordas simples. Esse instrumento é o precursor direto do violão moderno. Nada mais é do que um violão com a caixa acústica e encordoamento menores. No Brasil foi chamada de viola francesa.

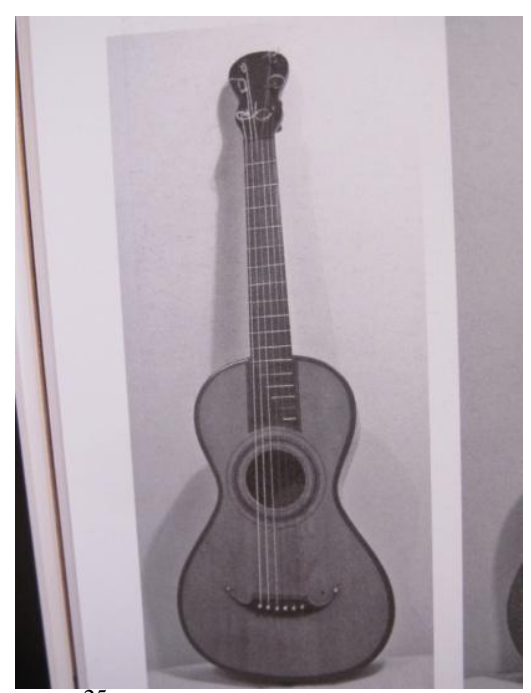

Figura 11 - Guitarra Romântica ${ }^{25}$ construída por Francois Roudhlof, por volta de 1820.

Assim, nós podemos resumir a história do violão a partir da vihuela, com um novo formato de caixa, em oito. Seguindo, vimos o surgimento da guitarra renascentista com quatro cordas e a afinação do gittern (em quartas, terças e quartas), que permanece no violão moderno. Derivada da guitarra renascentista, com um par de cordas a mais, surge a guitarra barroca que manteve a mesma afinação das cinco cordas de baixo do violão clássico. Por fim,

\footnotetext{
${ }^{24}$ Dados sobre a guitarra romântica disponível depoimento do Professor Nicolas de Souza em: <https://www.youtube.com/watch?v=MustE5Bs24c>. Acesso 17/09/2013.

${ }^{25}$ Imagem extraída do livro La Guitarra Mágica (LOUZAO, 2009, p.24).
} 
chegamos ao precursor do violão moderno, a guitarra romântica, que passa a ter seis cordas simples (BARROS, 2012).

\subsection{5 - O Requinto}

É um instrumento de origem espanhola, que faz parte da família do violão e, como veremos adiante, pode ter influencia direta no surgimento da configuração do cavaquinho. Segundo o historiador português Ernesto Veiga de Oliveira, o requinto "tem quatro cordas, o braço raso com o tampo e a seguinte afinação do grave para o agudo: ré-lá-dó\#-mi”" (OLIVEIRA, 1966, p. 140). É também chamado de guitarro, guitarrico ou guitarreta. Sua versão de cinco cordas tem muita proximidade com a guitarra barroca, inclusive a mesma afinação $^{26}$ (como vimos, essa afinação é correspondente às cinco cordas de baixo do violão).

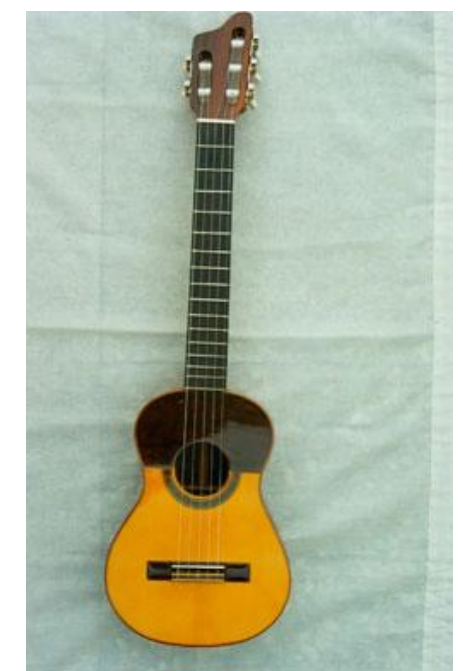

Figura 12 - Guitarrico ou requinto ${ }^{27}$

\section{5 - A origem do cavaquinho}

O cavaquinho é um instrumento musical feito de madeira, originário da família das guitarras europeias, semelhante ao violão e à viola caipira, contudo, com dimensões bem

${ }^{26}$ Veremos, nesta pesquisa, que existe uma afinação para o cavaquinho que corresponde às quatro cordas de baixo do violão. Essa afinação é usada por alguns cavaquinistas brasileiros e é a mesma afinação do extinto cavaquinho de Coimbra.

${ }^{27}$ Disponível em: http://funjdiaz.net/inst1.php?pag=22. Acesso em: 17/09/ 2013. 
reduzidas e com quatro cordas de aço, como as utilizadas na atualidade, ou de tripa, usadas no passado. É um instrumento melódico e harmônico de vasta popularidade no Brasil, tanto no meio urbano como no rural, com som vibrante e agudo.

No verbete do Dicionário Musical Brasileiro de Mário de Andrade, encontramos as seguintes informações sobre o cavaquinho:

Instrumento de cordas dedilhadas, afinadas, normalmente em ré-sol-si-ré. Jean Baptiste Debret observou a popularidade do instrumento: "É certo que no Brasil a cabana e o palácio são o berço comum da música. Por isso ouvese, dia e noite, o som da marimba do escravo africano, do violão ou do cavaquinho do homem do povo e a harmonia mais sabida do piano do homem rico." De origem portuguesa o cavaquinho também é conhecido como machete e braguinha. Mário de Andrade rejeita a afirmação de Balbi, segundo a qual o instrumento foi inventado por Joaquim Manoel, músico do Rio de Janeiro renomado, sobretudo, por tocar uma pequena viola francesa chamada cavaquinho (ANDRADE, 1989, p. 123).

Existem outras denominações para esse instrumento, tais como: braga, braguinho, braguinha, machete, manchete, marchete, machete de braga, machinho, machin, e ainda cavaco. No Havaí é conhecido como ukulele e na Indonésia é chamado de kerotjong.

Como consta no livro Escola Moderna do Cavaquinho, vários autores como Mário de Andrade, Oneyda Alvarenga, Renato Almeida e Câmara Cascudo afirmam que o cavaquinho tem origem portuguesa. Cascudo completa dizendo que esse instrumento teria sido levado para a Ilha da Madeira e, após absorver algumas modificações, se difundiu e chegou ao Brasil (CAZES, s/d, p. 08).

Tão associado com a música brasileira, o cavaquinho tem origem portuguesa e nasceu na cidade de Braga, região do Minho, no norte de Portugal, daí ser conhecido também como Braguinha. Além de ter sido levado para o Brasil, foi também para as províncias ultramarinas dos Açores e Ilha da Madeira e para outras colônias portuguesas como Goa, Cabo Verde e Macau e territórios onde os portugueses atuaram comercialmente, como Havaí e Indonésia (CAZES, 2010, p. 44).

No entanto, no livro Instrumentos Musicais Populares Portugueses, de autoria de Ernesto Veiga de Oliveira, e também no encarte do disco português Cavaquinho, de Júlio Pereira, encontramos outras versões sobre a origem do cavaquinho sugeridas pelos pesquisadores Gonçalo Sampaio e Jorge Dias.

Gonçalo Sampaio explica a sobrevivência das influências da cultura grega, que ele próprio sente na música da Região do Minho, aponta para uma possível relação entre o cavaquinho e os tetracórdios helênicos e acrescenta que o braguinha teria vindo para Braga 
nas mãos dos biscaínhos - vindos de Biscaia, hoje País Basco (SAMPAIO, 1933, p. 358). De fato, como já vimos na figura 12, existe na Espanha um instrumento semelhante ao cavaquinho: o requinto (OLIVEIRA, 1966, p. 140).

Jorge Dias também acredita que o cavaquinho pode ter vindo da Espanha, onde são encontrados instrumentos bem semelhantes e acrescenta:

Sem poder precisar a data da introdução, temos que reconhecer que o cavaquinho encontrou no Minho um acolhimento invulgar, como consequência da predisposição do temperamento musical do povo pelas canções vivas e alegres e pelas danças movimentadas. O cavaquinho, como instrumento de ritmo e harmonia, com o seu tom vibrante e saltitante, é como poucos, próprio para acompanhar viras, chulas, malhões, canas-verdes, verdegares e prins. Além disso, é no Minho notório o gosto pelo canto estridente e por vezes esganiçado das vozes femininas, onde predominam as notas altas, que se casam bem com o som agudo do cavaquinho (DIAS apud OLIVEIRA, 1966, p.140).

No país dos lusitanos, encontramos dois tipos de cavaquinho mais comuns: o minhoto, com dez trastes e a escala rasa, nivelada com o tampo; e o cavaquinho de Lisboa, com a escala elevada em relação ao tampo e dezessete trastes.

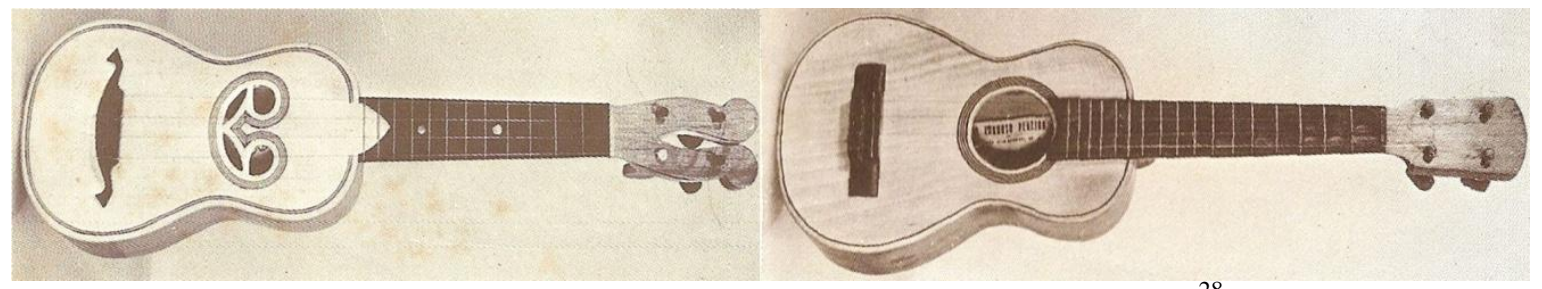

Figura 13 - Cavaquinho Minhoto e Cavaquinho de Lisboa ${ }^{28}$

Outro tipo é o cavaquinho do sul ou guitarrilho, com acabamento de luxo, decorado com madrepérolas e com o bojo no formato de pêra, porém muito pouco conhecido. Ver figura a seguir.

\footnotetext{
${ }^{28}$ Disponível em: http://www.oviolao.com.br/cavaquinho.htm. Acesso em: 14/10/2012.
} 


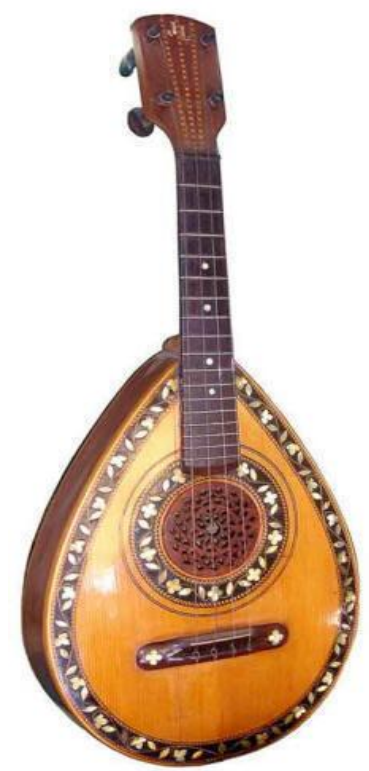

Figura 14 - Cavaquinho do $\mathrm{Sul}^{29}$

O cavaquinho pode ser afinado de diversas maneiras, que variam conforme as regiões, as formas musicais e até mesmo conforme seus executantes, como nos fala Ernesto Veiga:

A afinação natural parece ser ré-sol-si-ré, mas usa-se também sol-sol-si-ré, (ou la-la-dó\#-mi). Certos tocadores de Braga usam, porém, além destas, outras afinações, próprias de certas formas em que a corda mais aguda (ré) é ora a primeira ora a terceira: a afinação para o varejamento (com a primeira mais aguda), que corresponde a sol-sol-si-ré atrás indicada; a afinação para malhão e vira na moda velha, mais antiga, (sol-ré-mi-la) (também com a primeira mais aguda); em Barcelos preferem sol-dó-mi-la (afinação da Maia); e outras afinações de malhão e vira, e outras ainda com a terceira mais aguda; etc. Hoje se usa o cavaquinho também para o fado, com afinação correspondente, e igualmente com a primeira mais aguda (OLIVEIRA, 1966, p.140).

É fundamentalmente no Minho que o cavaquinho tem expressiva presença popular, ligado às manifestações musicais locais. O cavaquinho minhoto tem a escala rasa, no mesmo nível do tampo, doze trastes e a boca da caixa é, na maioria dos casos, em forma de "raia", sendo também encontrada a boca redonda. Esse instrumento mede $52 \mathrm{~cm}$ de comprimento total, sendo $12 \mathrm{~cm}$ para a cabeça, $17 \mathrm{~cm}$ para o braço e $23 \mathrm{~cm}$ para a caixa. De largura, seu bojo tem $15 \mathrm{~cm}$ na parte inferior e $11 \mathrm{~cm}$ na parte superior. Suas cordas, da pestana ao cavalete, medem $33 \mathrm{~cm}$. Geralmente, a altura da caixa é de aproximadamente $5 \mathrm{~cm}$, porém existem em algumas regiões do Minho, como na região de Bastos, cavaquinhos com a altura

\footnotetext{
${ }^{29}$ Disponível em: www.jose-lucio.com/0\%20Cav_2011/cavaquinho.htm. Acesso em: 14/10/2012.
} 
da caixa acústica bem reduzida, o que proporciona um som mais estridente. Esses instrumentos recebem a denominação de machinhos (OLIVEIRA, 1966, p. 139).

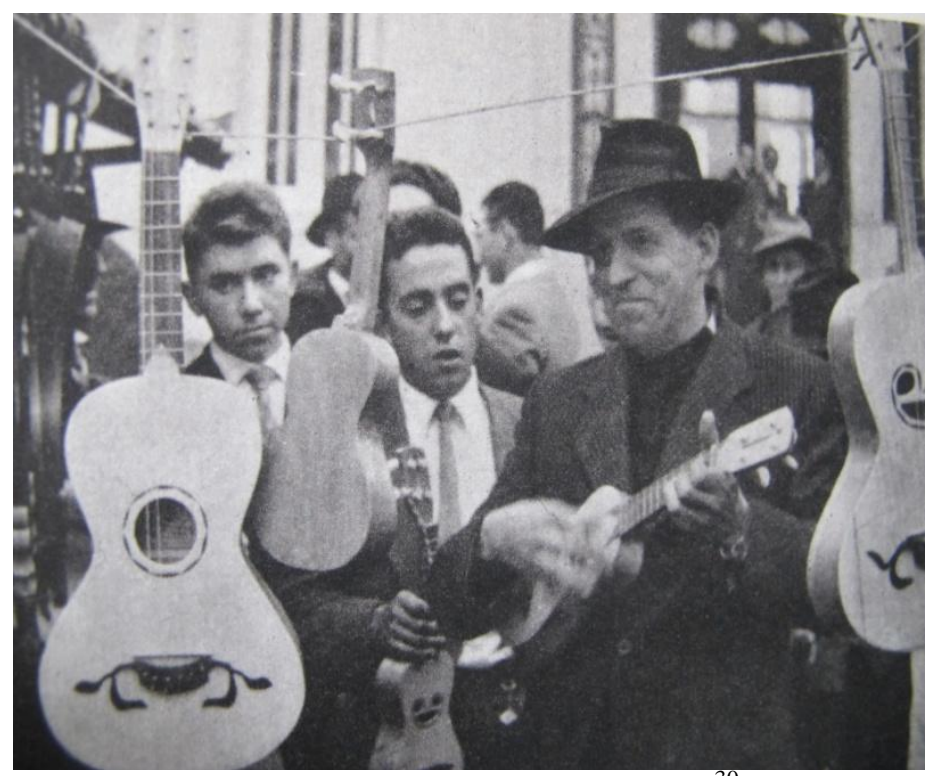

Figura 15 - Feira de São Martinho ${ }^{30}$

A imagem acima mostra uma passagem da Feira de São Martinho, na Tenda do Violeiro em Penafiel - Portugal. Podemos observar vários cordófonos que estão à venda e um músico de chapéu, que toca um cavaquinho minhoto fazendo um rasgueado, sendo observado de perto por outro senhor que segura outro minhoto.

Segundo as fontes iconográficas, o cavaquinho minhoto é construído com formatos variados de cavaletes, tendo um lado reto e o outro lado com formas levemente arredondadas, podendo ainda, por vezes, ter pequenas "asas" decorativas.

O cavaquinho geralmente toca-se de rasgueado, com os quatro dedos da mão direita, ou apenas com o polegar e o indicador. Mas um bom tocador faz a melodia nas cordas agudas que se destaca sobre o rasgueado e, também, faz os acordes nas cordas superiores. $\mathrm{O}$ cavaquinho é um dos instrumentos favoritos e mais populares das rusgas minhotas e pode ser tocado sozinho, fazendo o acompanhamento de cantores ou, como é mais comum, em conjunto com a viola, o violão, o acordeão e ainda instrumentos de percussão como o tambor, o reco-reco e ferrinhos (triângulo) (OLIVEIRA, 1966, p. 140).

O minhoto, ainda no fim do século XIX, era bastante comum na região de Coimbra. Conhecido como machinho, fazia parte dos festejos de S. João e das serenatas. Há poucas 
décadas ele ainda era encontrado, geralmente tocado por estudantes minhotos. O cavaquinho de Coimbra era afinado, de acordo com a viola da região: ré-sol-si-mi. Suas dimensões são um pouco menores que o cavaquinho minhoto: $50 \mathrm{~cm}$ de comprimento total, sendo 9,5 cm de cabeça, $17 \mathrm{~cm}$ de braço e 23,5 $\mathrm{cm}$ de caixa (com 33,5 $\mathrm{cm}$ da pestana ao cavalete); o bojo superior tem 10,5 cm de largura, e o inferior 13,5 cm; a altura da caixa é de $3 \mathrm{~cm}$ em cima, e de 3,4 cm em baixo. O cavaquinho de Coimbra se extinguiu, tanto no uso, como na fabricação (OLIVEIRA, 1966, p. 141).

O cavaquinho de Lisboa se assemelha ao cavaquinho minhoto no aspecto geral, porém com dimensões diferentes. Sua escala é elevada em relação ao tampo, possui 17 trastes e se prolonga até junto à boca do instrumento. Seu braço é um pouco mais curto e sua caixa acústica é mais comprida, mais larga e mais alta. O cavalete é reto como uma régua espessa, onde se encontra o rastilho, encaixado num rasgo horizontal escavado no próprio cavalete. Foi em Lisboa que, ao que tudo indica, se começou a usar a palheta ou plectro para se tanger as cordas do cavaquinho (ibidem). Essas mudanças conferiram ao instrumento uma maior sonoridade e projeção de som. A escala elevada (também chamada de espelho ou régua) é feita de madeira de maior densidade que, além de ajudar a melhorar o som do cavaquinho, proporciona uma proteção contra eventuais empenos (CAZES, s/d) ${ }^{31}$.

Em Lisboa, o cavaquinho se junta ao bandolim, ao violão e à viola para formar o conjunto das chamadas tunas (grupos musicais formados por cordófonos). Na capital, adquire ares urbanos e burgueses e passa a ser utilizado pelos professores de dança, quando iam às casas onde não havia piano, no século XIX (CAZES, 2013).

O cavaquinho alcançou outras terras, como o Algarve, onde é tocado sozinho, ou ao lado de bandolins, violas, violões, guitarras e outros instrumentos. Assim como em Lisboa, adquire aqui um ar urbano e burguês. O Dicionário Musical, de Ernesto Vieira, e também o Grove Dictionary of Music, mencionam a existência do cavaquinho nos Açores. Veiga aponta para a existência do instrumento na Prainha do Norte, nas ilhas do Pico, do Faial, na aldeia dos Flamengos, perto da ilha Horta e na Terceira onde hoje são construídos cavaquinhos apenas por encomenda dos americanos do aeroporto das Lajes, ou destinados a terceirenses que habitam a América do Norte, e rotulados de ukulele (OLIVEIRA, 1966, p. 141- 42).

\footnotetext{
${ }^{31}$ Disponível em <http://ensaios.musicodobrasil.com.br/henriquecazes-ocavaquinho.pdf > Data de acesso: 03 de dezembro de 2011.
} 
Na Ilha da Madeira encontramos também o cavaquinho, que nessa região é conhecido como machete, machete de braga, braga, braguinha ou cavaquinho. Suas características construtivas são as mesmas do cavaquinho de Lisboa, com escala elevada, dezessete trastes e a boca redonda. É afinado em ré-sol-si-ré, do grave para o agudo, a afinação tradicional dos cavaquinhos brasileiro e cabo-verdiano.

O machete madeirense, no contexto social, parece ter herdado, por um lado, a compatibilidade festiva vinda das terras do Minho, quando tocado de rasgueado, fazendo um suporte rítmico-harmônico. E, por outro lado, mostra seu caráter urbano e burguês, apreendido do cavaquinho de Lisboa, quando participa das tunas, fazendo solos melódicos tocados com palhetas ou, preferencialmente, com a unha do polegar direito, alternando com os rufos dos dedos anelar, médio e indicador, uma técnica extremamente difícil. Na ilha, ainda podemos observar dois tipos de machete, o rural e o urbano, que apesar de idênticos quanto forma e dimensões, diferem, entre si, no acabamento. O primeiro é construído de forma muito simples e o segundo com madeiras especiais e acabamentos sofisticados (OLIVEIRA, 1966, p. 141- 42).

Em entrevista concedida ao autor deste trabalho, o professor Henrique Cazes menciona que a importância cultural do machete na Ilha da Madeira chega a ser maior que no próprio continente português. Cazes observa que foi recentemente descoberto na Ilha da Madeira pelo musicólogo Manoel Moraes, um volume de peças para machete e guitarra francesa (guitarra romântica), datado de 1846, com um caráter de música de câmara, de cuja existência, não se tinha conhecimento. Um material bem particular do cavaquinho da Ilha da Madeira, sofisticado, registrado em partitura (CAZES, 2013). Sobre o Professor Manoel Moraes, destacamos nota da escritora madeirense Paula Henriques:

O professor foi distinguido pelo "valioso e incomparável contributo para a preservação e divulgação do patrimônio musical madeirense", que se traduziu na investigação, recuperação, transcrição e colaboração na publicação de repertório musical para o braguinha do século XIX, também conhecido como machete (HENRIQUES, 2013).

Existe também na Ilha da Madeira um instrumento que devido ao seu formato pode ser confundido com o cavaquinho, o rajão. Trata-se de um cordofone muito semelhante ao machete, entretanto, um pouco maior. 


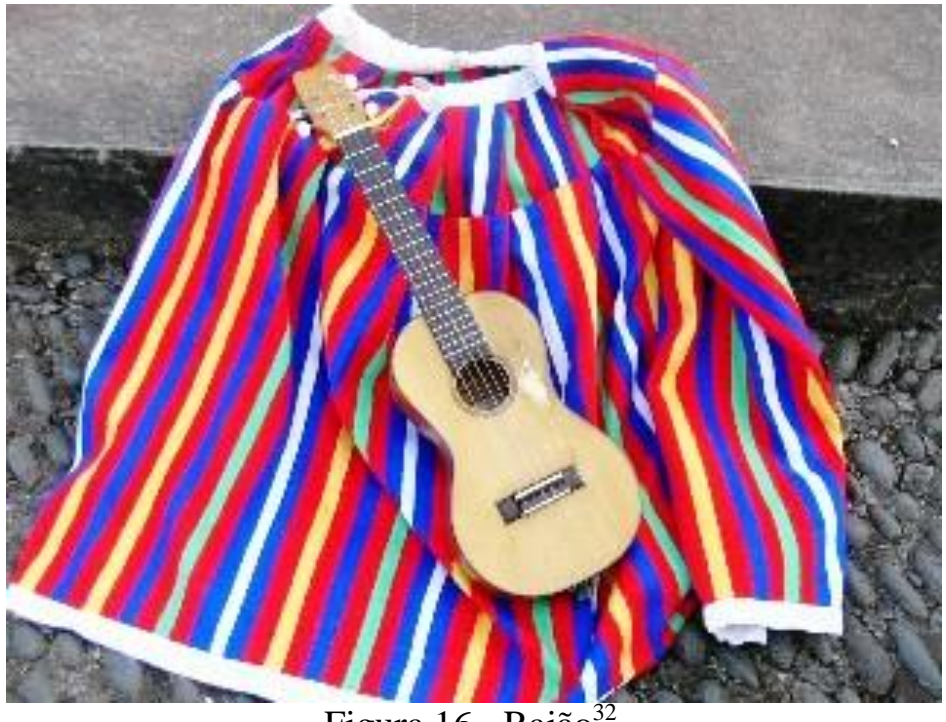

Figura 16 - Rajão

Seu comprimento é de $66 \mathrm{~cm}$, dos quais $32 \mathrm{~cm}$ são de caixa acústica, com $21 \mathrm{~cm}$ de largura. Seu braço tem 17 trastes e 5 cordas afinadas em ré-sol-dó-mi-la e também em mi-laré-fá\#-si e a corda mais grave é a terceira, a corda do meio. Por ser um instrumento tipicamente acompanhador, é tocado com a técnica de rasgueado (OLIVEIRA, 1966, p. 142).

Alguns autores madeirenses como Carlos Santos e Eduardo Pereira consideram esse instrumento uma invenção insular, uma imitação do violão, em tamanho menor. Ernesto Veiga de Oliveira aponta uma possível influência do guitarro andaluz, instrumento espanhol de cinco cordas que tem a mesma afinação do rajão e do extinto machinho de cinco cordas, citado no Regimento do Oficio de Violeiros de Guimarães, de 1719 (OLIVEIRA, 1966, p. 141- 42). Nota-se que, tanto na primeira hipótese quanto na segunda, a herança espanhola se faz sentir.

Vimos no Regimento dos Violeiros, de Guimarães, de 1719, que aí se construíram machinhos de cinco cordas (além de outros de quatro que correspondem aos atuais), sendo por isso de admitir que tenha havido no continente um tipo maior que corresponderia ao cavaco (mencionado por vários autores), depois desaparecido, e que, levado para a Madeira, aí subsistiu, tendo certamente modificado seu tipo originário, no que se refere à forma do braço e número de trastes, por influência certamente do violão, difundido e popularizado nos princípios do século XIX, e que tem essas características. E essa hipótese parece ser reforçada ainda com a consideração da afinação do rajão, idêntica à do guitarro espanhol, antecessor presumível do cavaco - ou seja, esse machete de cinco cordas do regimento de 1719 (OLIVEIRA, 1966, 142).

\footnotetext{
${ }^{32}$ Disponível em: http://www.gfcasailhadamadeira.com.br/instrumentos.html. Acesso em: 14/10/2012.
} 
Vimos que, de uma maneira geral, o cavaquinho minhoto é tocado de rasgueado nas festas populares, fazendo acompanhamentos harmônicos e tem o velho tipo de braço raso de doze trastes. Enquanto que os instrumentos de caráter urbano e burguês, de Lisboa, Algarve e Ilha da Madeira, menos presos à tradição, são usados como instrumentos harmônicos e melódicos.

\section{6 - O cavaquinho e as grandes navegações}

Como mencionado no decorrer desta pesquisa, no período das grandes navegações, o cavaquinho foi levado pelos portugueses a outros países e colônias portuguesas, ajudando a formar suas culturas. Fazemos aqui uma breve abordagem com o objetivo de trazer ao leitor uma noção sobre a presença do cavaquinho em terras do além-mar.

O cavaquinho chegou ao Havaí levado pelo navegante madeirense João Fernandes, comandante do barco a velas Ravenscrag, que aportou em Honolulu no dia 23 de agosto de 1879, trazendo 419 imigrantes portugueses com destino às plantações de cana-de-açúcar. No desembarque, após quatro meses e vinte e dois dias de viagem, os portugueses comemoraram muito tocando os instrumentos que haviam trazido. João Fernandes desceu da embarcação tocando um cavaquinho e encantou os havaianos que logo o rebatizaram de ukulele, que na língua local significa pulga saltitante, possivelmente uma referência aos pequenos saltos, que a mão esquerda do executante, faz no braço do instrumento (CAZES, 2012). No Grove Dictionary of Music and Musicians, encontramos a seguinte nota sobre o ukulele:

Um pequeno instrumento como violão, com quatro cordas dedilhadas e derivado do praticamente idêntico machete da braça, levado para o Havaí (então Ilhas Sandwich) por imigrantes da Madeira, no final do século 19 (GROVE, 1980, p.323).

Existem ukuleles que são construídos com a mesma forma dos cavaquinhos de Lisboa, da Ilha Madeira e do Brasil, isto é, com o braço em ressalto e dezessete trastes; mas os ukuleles de fabricação inglesa seguem a linha do cavaquinho minhoto, com o braço no mesmo nível do tampo e doze trastes. No Havaí existe ainda outro modelo de ukulele, conhecido pelo nome de taro-patch fiddle, que se relacionaria com o rajão madeirense, por ser maior, como um violão pequeno de quatro e cinco cordas (OLIVEIRA, 1966, p. 143). 


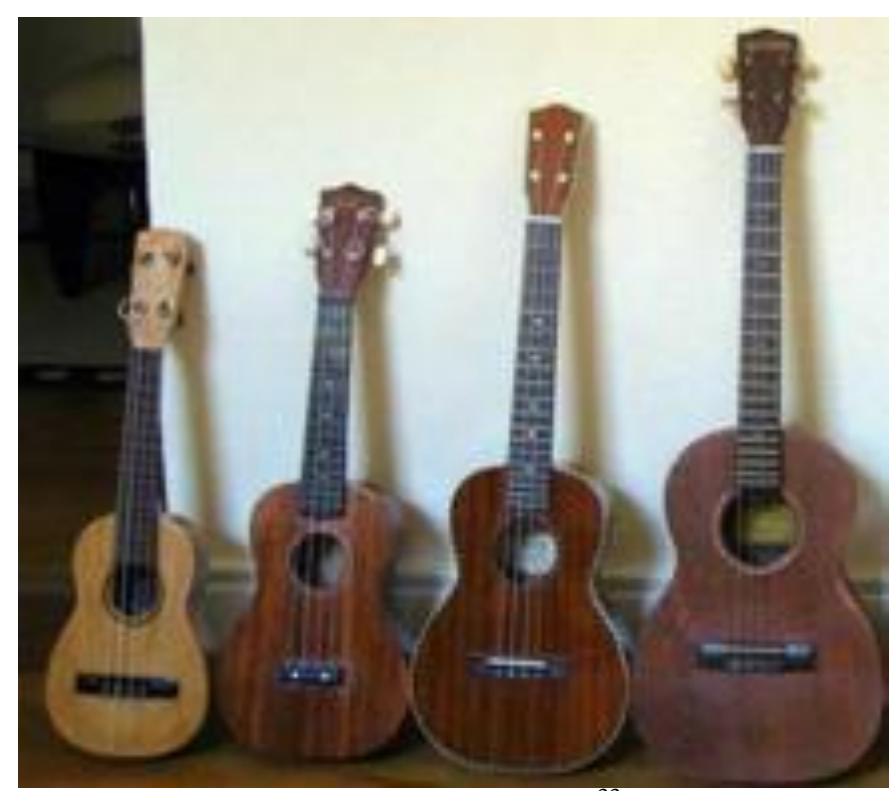

Figura 17 - Ukuleles ${ }^{33}$

$\mathrm{Na}$ figura acima, da esquerda pra direita, podemos ver os quatros principais tamanhos de ukuleles hoje fabricados: o soprano, com $53 \mathrm{~cm}$ de comprimento, o concerto, com $58 \mathrm{~cm}$, e o tenor, com 66 cm, são afinados de cima para baixo em sol-dó-mi-la; o barítono, com 76 $\mathrm{cm},{ }^{34}$ é afinado em ré-sol-si-mi. Outra curiosidade é que suas cordas são de nylon e a quarta corda (de baixo para cima) é aguda, o que proporciona uma sonoridade bem particular ao instrumento havaiano, que é tocado de rasgueado ou dedilhado.

O ukulele tornou-se símbolo da música havaiana e "é muito popular nos Estados Unidos" (HENRIQUE, 2006, p. 171). Sua divulgação está em franca expansão pelo mundo ${ }^{35}$, através de sites e festivais em países como Canadá, Austrália, Inglaterra, Alemanha, França, Holanda, Suécia, Espanha, Itália, Irlanda, Polônia, República Checa, Bélgica, México, Japão, Tailândia e Nova Zelândia. Aqui no Brasil tem conquistado músicos e ouvintes especialmente na área da música popular.

Em Cabo Verde, o cavaquinho tem grande popularidade e é praticamente igual ao cavaquinho brasileiro, tanto na constituição física e na afinação tradicional (ré-sol-si-ré), como também na maneira de tanger as cordas, com a palheta. Um olhar mais atento poderá

\footnotetext{
${ }^{33}$ Disponível em: https: //proukulele.wordpress.com. Acesso em: 27/03/2015.

${ }^{34}$ Disponível em: http://ukulelept.blogspot.com.br/2009/12/soprano-concerto-tenor-ou-baritono.html. Acesso em: 09/04/2015.

${ }^{35}$ Informações extraídas do site: http://www.cavaquinhos.pt/pt/CAVAQUINHO/Mundo.htm. Acesso em: $04 / 03 / 2015$.
} 
identificar, nas fontes iconográficas, que o braço do cavaquinho cabo-verdiano é um pouco mais largo que o braço do cavaquinho brasileiro.

Segundo a pesquisadora Gláucia Nogueira, o cavaquinho em Cabo Verde é mais utilizado como instrumento acompanhador.

O cavaquinho está bem presente na música cabo-verdiana, fazendo parte habitualmente dos grupos acústicos, nos quais tem sempre a função de marcar o ritmo. Rara é a sua utilização como instrumento solista (NOGUEIRA, 2013). ${ }^{36}$

No depoimento ${ }^{37}$ gravado e editado por Die4films, o músico e luthier Luís Baptista, filho do Mestre Baptista e irmão do cavaquinista e também construtor Bau, declara que o cavaquinho é usado em ritmos tradicionais como a morna, a coladeira, o cola São João, o samba cabo-verdiano e ainda na mazurca, importada da Polônia (BAPTISTA, 2012).

No referido depoimento, entre uma fala e outra, Luis Baptista faz pequenas demonstrações das levadas (palhetadas) de cavaquinho, nos ritmos de Cabo Verde, o que me levou a fazer uma comparação com alguns gêneros musicais ocorrentes no Brasil. A morna lembra o nosso samba-canção; a coladeira, o baião; o cola São João, o Jongo e o samba de Cabo Verde, por sua vez, se parece com nosso samba. A respeito da família Baptista, Gláucia Nogueira esclarece:

Na sua oficina na ilha de S. Vicente, Mestre Baptista ensinou todos os seus filhos a construir instrumentos. Um deles é Bau, músico que, ao conhecer o cavaquinho solado do brasileiro Waldir Azevedo, enveredou por essa via, ao perceber os recursos do instrumento para lá da marcação do ritmo (NOGUEIRA, 2013).

\footnotetext{
${ }^{36}$ Disponível em: http://www.cavaquinhos.pt/pt/CAVAQUINHO/Cavaquinho\%20cv\%20Historia.htm. Acesso em: 09/04/2015.

${ }^{37}$ Disponível em: https://www.youtube.com/watch?v=dSTr01fSY0I. Acesso em: 16/03/2015.
} 


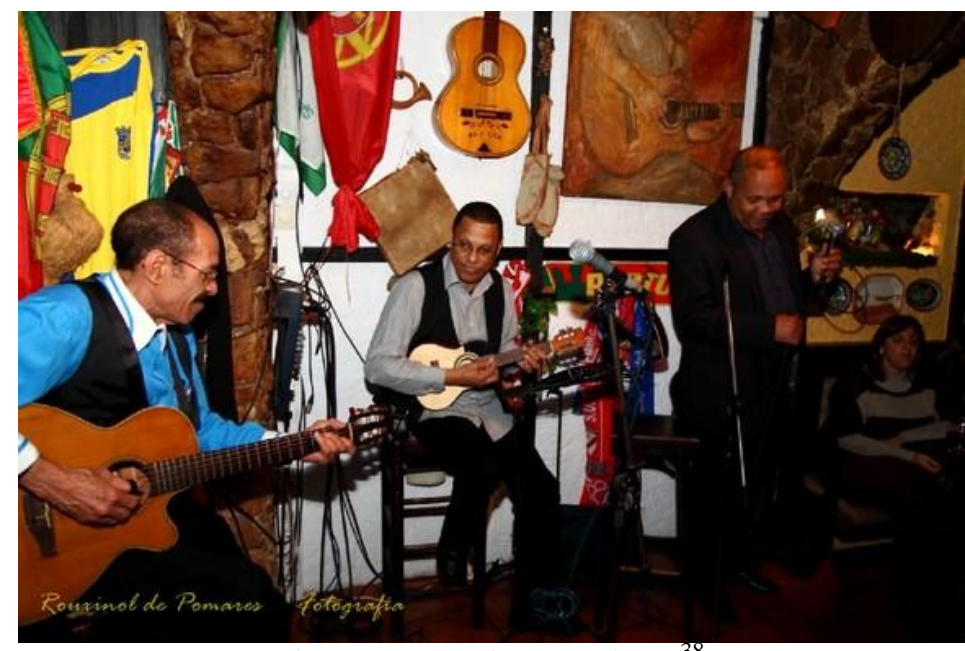

Figura 18 - Trio Morabeza ${ }^{38}$

Na foto acima vemos o Trio Morabeza em apresentação na Taverna dos Trovadores, em Sintra, Portugal. O trio, que é formado por Mário Rui na voz, Armando Tito no violão e Zé Antônio no cavaquinho, possui em seu currículo o peso de ter acompanhado em apresentações pelo mundo a conhecida cantora Cesária Évora.

O cavaquinho na Indonésia, onde é chamado de kerotjong, viola de kerotjong, keroncong ou ainda ukulele, faz parte do gênero musical kerotjong, geralmente constituído por uma flauta, um violão, um violino, uma voz masculina ou feminina, um ou dois kerotjongs e ainda um violoncelo e (ou) um contrabaixo acústico tocado(s) em pizzicato. $\mathrm{O}$ referido gênero musical teve sua semente plantada no século XVI, no encontro de marujos portugueses com nativos na Indonésia, como observa Ernesto Veiga de Oliveira:

[...] instrumento, que ocorre na Indonésia - o ukelele, ou kerontjong, como acompanhante na orquestra que leva o mesmo nome de kerontjong, a par de uma viola grande (guitarre), um violoncelo ou contrabaixo, e um alto (viole). Esta orquestra corresponde a um gênero musical indonésio que surge no começo do século XVI, por contacto com a música portuguesa, influenciada, conforme as regiões, pêlos estilos tradicionais, como o gamelan ${ }^{39}$ (OLIVEIRA, 1966).

\footnotetext{
${ }^{38}$ Disponível em: http://rouxinoldepomares.blogs.sapo.pt/621285.html. Acesso em: 21/03/2015.

${ }^{39}$ Gamelão: Conjunto musical encontrado em comunidades que integram desde grandes cortes, até cidades e aldeias remotas (GROVE, 1994).
} 


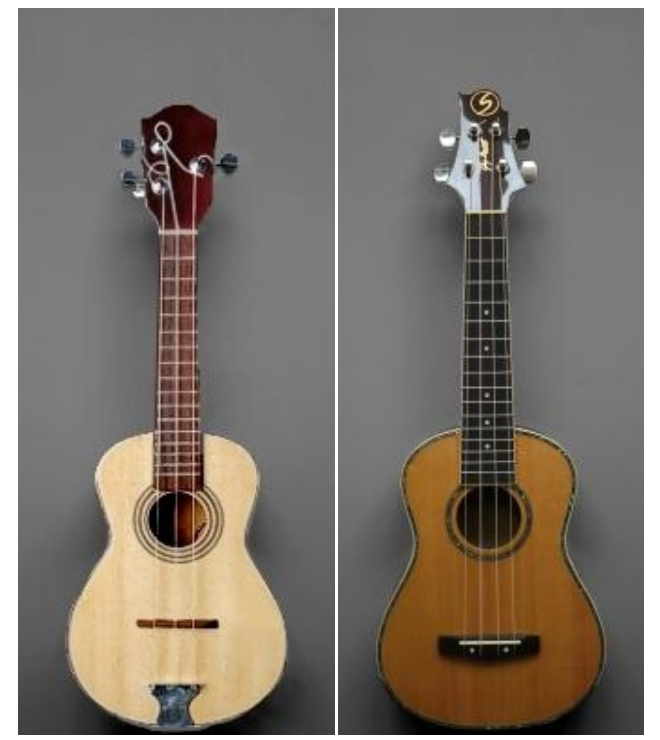

Figura 19 - Cuk

Figura 20 - $\mathrm{Cak}^{40}$

Nas figuras 19 e 20 podemos ver dois tipos de kerotjong existentes na Indonésia, o modelo $C u k$, com três cordas e afinação sol-si-mi e o modelo $C a k$, com quatro cordas, afinado em ré-ré-sol-si ${ }^{41}$.

Para Angola, o cavaquinho foi levado por marinheiros portugueses e também por marinheiros brasileiros. Sua presença em terras do sudoeste africano auxiliou o desenvolvimento do Ramkie, cordofone que tem uma lata de óleo ou similar como caixa de ressonância. Ele tem três ou quatro cordas, por vêzes seis, feitas de linha de pescaria ou de cabos de freio de bicicleta e seu braço pode ter ou não trastes. O instrumento aparentemente tem sido executado com o uso de acordes repetitivos. Sobre o assunto, encontramos algumas linhas no Grove:

Instrumentos de cordas ibéricos dos séculos 17 e 19 foram levados para as cidades costeiras de Angola por marinheiros portugueses, brasileiros e outros. Entre eles estava o cavaquinho, um cordofone de cordas dedilhadas que se espalhou pelo mundo, levando ao desenvolvimento do Ramkie no sudoeste africano (GROVE, 1980, p. 677).

Como citado anteriormente, o cavaquinho também migrou para outras terras como Goa, na Índia; Moçambique e Guiné Bissáu, na África e Macau, na China. Mas foi no Brasil que o cavaquinho encontrou um ambiente propício para se desenvolver. É amplamente usado no samba e no choro, estilos musicais nos quais sua participação é fundamental, e também

\footnotetext{
${ }^{40}$ Figuras 19 e 20. Disponíveis em: <http://cavaquinhos.pt/pt/CAVAQUINHO/Indonesia.htm>. Acesso em: $18 / 03 / 2015$.

41 Afinações do Cuk e do Cak disponíveis em: https://en.wikipedia.org/wiki/Stringed_instrument_tunings. Acesso em: 17/06/2015.
} 
participa de uma gama de manifestações culturais regionais, emprestando sua alegria, seu balanço e seus acordes de sonaridade aguda.

O pesquisador Jorge Dias, em participação no Congresso Internacioanal de Etnografia, ocorrido em Santo Tirso, escreveu:

Uma viagem através de grande parte dos estados brasileiros nos ajudou a colher bastante informação acerca do cavaquinho. Em parte alguma se encontra esse instrumento tão difundido e popularizado como no Brasil. Tivemos oportunidade de deparar inúmeras vêzes com tocadores de cavaquinho (DIAS, 1963).

No próximo capítulo, faremos uma abordagem com o objetivo de esclarecer como se deu a fusão do cavaquinho com a musicalidade que aflorou no processo de misturas culturais ocorrido no Brasil e como esse instrumento se tornou um dos pilares da Música Popular Brasileira. 


\section{CAPÍTULO 2 - O CAVAQUINHO TRADICIONAL BRASILEIRO}

Como já foi citado nesta pesquisa, o cavaquinho também chegou ao Brasil. Foi aqui, em terras brasileiras, que o cavaquinho teve suas possibilidades sonoras mais exploradas e desenvolvidas, ao ponto de surgirem aqui alguns dos melhores cavaquinistas do mundo, como observa Henrique Cazes em entrevista a Meri Fraga, na página on line da Escola de Música da $\mathrm{UFRJ}^{42}$ :

Foi no Brasil que o cavaquinho atingiu um grau maior de desenvolvimento, justamente por ser usado em gêneros como o samba e o choro, que desde a década de 1930, representam oportunidades de profissionalização. E aqui tivemos Waldir Azevedo, que revelou as possibilidades do instrumento como solista, fazendo muito sucesso e influenciando várias gerações (CAZES, 2014).

Sobre a chegada do cavaquinho no Brasil, Henrique Cazes fala no documentário Apanhei-te Cavaquinho ${ }^{43}$ :

Não se sabe bem quando, certamente antes da chegada da família real em 1808. O cavaquinho já estava aqui, metido com o lundu, com a modinha, os primeiros gêneros da música brasileira, participando dessa música popular que nascia (CAZES, 2012).

Cazes completa, em entrevista ao autor deste trabalho, que o cavaquinho provavelmente teria vindo para o Brasil através dos madeirenses. Aqui, esse instrumento também foi chamado de machete. Inclusive, Machado de Assis, romancista brasileiro, escreveu um conto intitulado $O$ Machete (1878), onde fala do fascínio que esse instrumento exercia sobre as pessoas numa sociedade que, na época, estava dividida entre a cultura europeia e a cultura brasileira que ganhava força. Machado de Assis nos faz ver o machete como um símbolo do sentimento de brasilidade. Ele mostra que essa simbologia associada ao cavaquinho, de afinidade com o movimento, o sentimento popular, com o balanço rítmico, o swing, já existia mesmo antes do samba (CAZES, 2013).

No que diz respeito aos aspectos construtivos, o cavaquinho brasileiro é maior que o cavaquinho português, tendo herdado as características físicas do cavaquinho de Lisboa e do cavaquinho da Ilha da Madeira (OLIVEIRA, 1966, p. 143). Tirando as medidas do meu

\footnotetext{
${ }^{42}$ Disponível em: http: //www.musica.ufrj.br/index.php?option=com_content\&view=article\&id=1694:2015-0311-01-30-40\&catid=55:destaques\&Itemid=149. Acesso em: 24/03/2015.

43 CAZES, Henrique. Apanhei-te Cavaquinho. $1^{\circ}$ Episódio, 2012. Disponível em: www.youtube.com/watch?v=30ETxHEAksY. Acesso em: 28/03/ 2014.
} 
cavaquinho, da marca Do Souto Modelo Waldir 1984, pude constatar que seu comprimento total é de $59 \mathrm{~cm}$, sendo $13 \mathrm{~cm}$ para a cabeça, $18 \mathrm{~cm}$ para o braço e $28 \mathrm{~cm}$ para a caixa; seu bojo tem de largura, $22,5 \mathrm{~cm}$ na parte maior e $16,5 \mathrm{~cm}$ na parte menor; as cordas, da pestana ao cavalete, medem $35 \mathrm{~cm}$. A caixa de ressonância tem uma altura de $08 \mathrm{~cm}$, próximo da conexão com o braço, e de $09 \mathrm{~cm}$ em sua base. Sua escala tem 19 trastes e sob a primeira corda 20 trastes, o que aumenta em três notas a extensão do instrumento.

Existem ainda no Brasil dois modelos de cavaquinho que estão gradativamente sendo esquecidos. O primeiro que cito é o cavaquinho modelo Paulistinha. Suas dimensões ${ }^{44}$, de cabeça, braço e escala são as mesmas do cavaquinho convencional, a diferença está no tamanho da caixa acústica, que é menor, no comprimento $(25 \mathrm{~cm})$, na largura $(14 \mathrm{~cm}$ na parte menor e 19 na maior) e na altura $(4,7 \mathrm{~cm})$. A imagem abaixo ilustra as diferenças entre o cavaquinho modelo Paulistinha e o cavaquinho convencional.

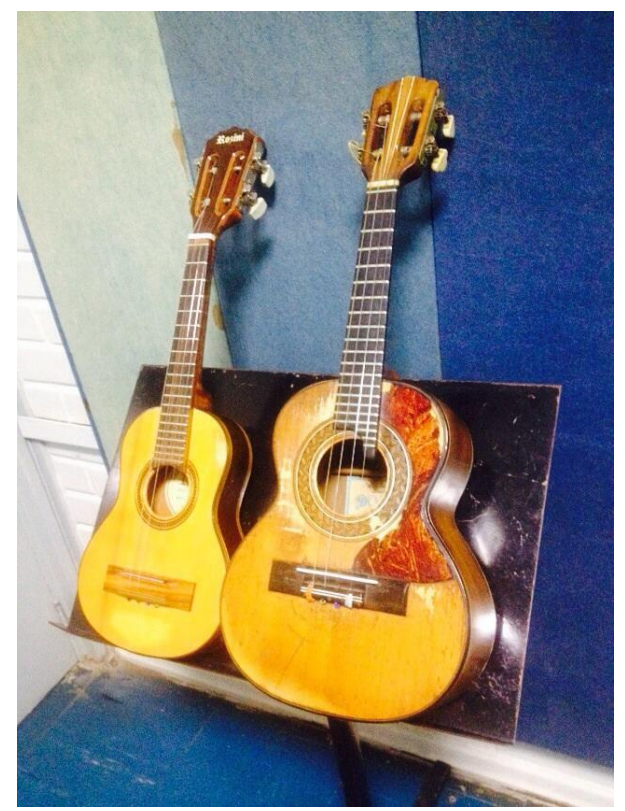

Figura 21 - Cavaquinho modelo Paulistinha e o cavaquinho convencional ${ }^{45}$

O outro é o modelo Canhoto que tem como característica a profundidade, altura da caixa acústica reduzida de aproximadamente $06 \mathrm{~cm}$. Esses tipos de instrumentos produzem um som mais "seco", que não tem muita sustentação, menor duração das notas, sendo mais usados como instrumentos acompanhantes. É importante ressaltar que as medidas dos

\footnotetext{
${ }^{44}$ As medidas dos cavaquinhos modelos Paulistinha e Canhoto foram conferidas pelo autor desta pesquisa.

${ }^{45}$ Foto tirada por mim na Escola de Música de Brasília, no dia 03/04/2015.
} 
cavaquinhos podem variar de acordo com o fabricante e com o gosto do cliente. Uma caixa acústica maior produz um som mais médio-grave, enquanto uma menor realça os agudos.

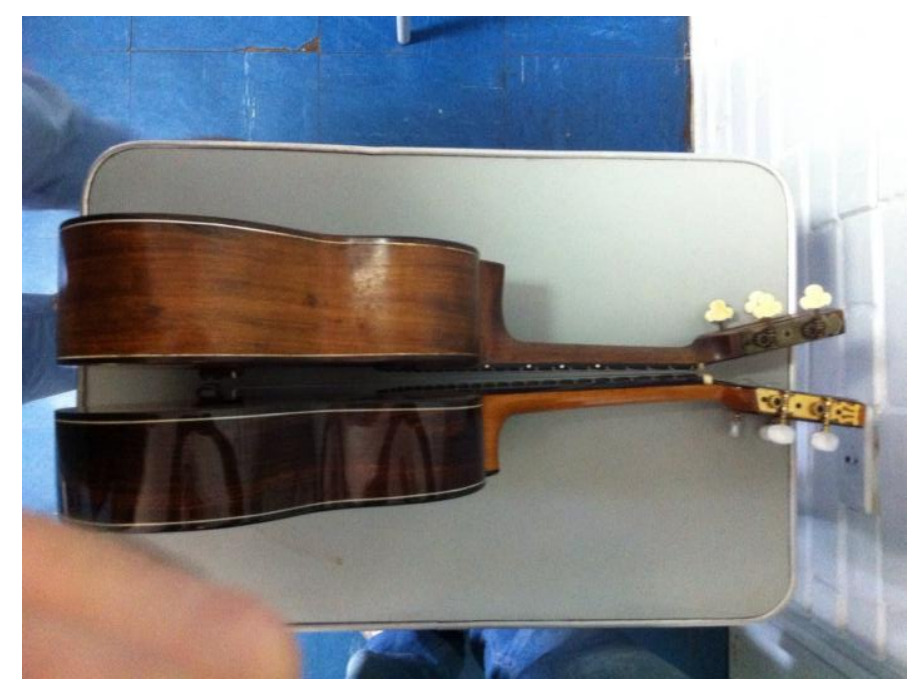

Figura 22 - Cavaquinhos convencional e modelo Canhoto ${ }^{46}$

A respeito dos materiais usados na fabricação do cavaquinho brasileiro, segundo consta no livro Escola Moderna do Cavaquinho, no tampo (14) é usado o pinho sueco, cedro ou cedar; na ilharga (7) e no fundo (8) usa-se jacarandá, imbuia, faia, caviúna ou plátano, etc. A escala (12) ou régua, que é dividida em semitons pelos trastes (11), pode ser de ébano ou jacarandá; o braço (3), de cedro ou mogno. O cavalete (13), peça onde se prendem as cordas, pode ser de jacarandá, imbuia ou ébano, está fixado sobre o tampo e nele inserido o rastilho (12), de osso (plástico ou marfim), responsável pela altura e tensão das cordas. O timbre ${ }^{47}$ do instrumento também é influenciado pelo material do rastilho. A pestana (1), de osso, se encontra no início do braço, junto à cabeça, tem função semelhante ao rastilho, e ainda divide as cordas em distâncias iguais (CAZES, s/d. p.10).

$\mathrm{Na}$ figura a seguir, o leitor pode identificar as partes do cavaquinho citadas acima e outras que descrimino a seguir: traste zero (2), que se encontra ao lado da pestana e é responsável pela altura das cordas; cabeça (9), geralmente possui um formato característico do fabricante e é onde são fixadas as cravelhas (10), aparato mecânico responsável pela fixação e

\footnotetext{
${ }^{46}$ Foto tirada pelo autor, na Escola de Música de Brasília, em 09/06/2015.

${ }^{47}$ Qualidade (ou cor) do som característico de um instrumento ou de uma voz (ISAACS \& MARTIN, 1985).
} 
afinação das cordas. Temos ainda a boca (4), a roseta (5) que enfeita o instrumento e reforça as bordas da boca.

O cavaquinho que aparece na foto é propriedade do autor desde 1984, quando foi adquirido na loja Ao Bandolim de Ouro. Optamos pela colocação de um protetor de palhetas (6) que era usado na época. A decisão foi acertada, pois devido aos arranhões que o instrumento apresenta nas partes sem a proteção, decorrentes das palhetadas de anos de prática, provavelmente haveria um orifício na madeira se não tivesse usado o protetor. Já vi cavaquinho com este tipo de danificação.

Figura 23 - Partes do Cavaquinho

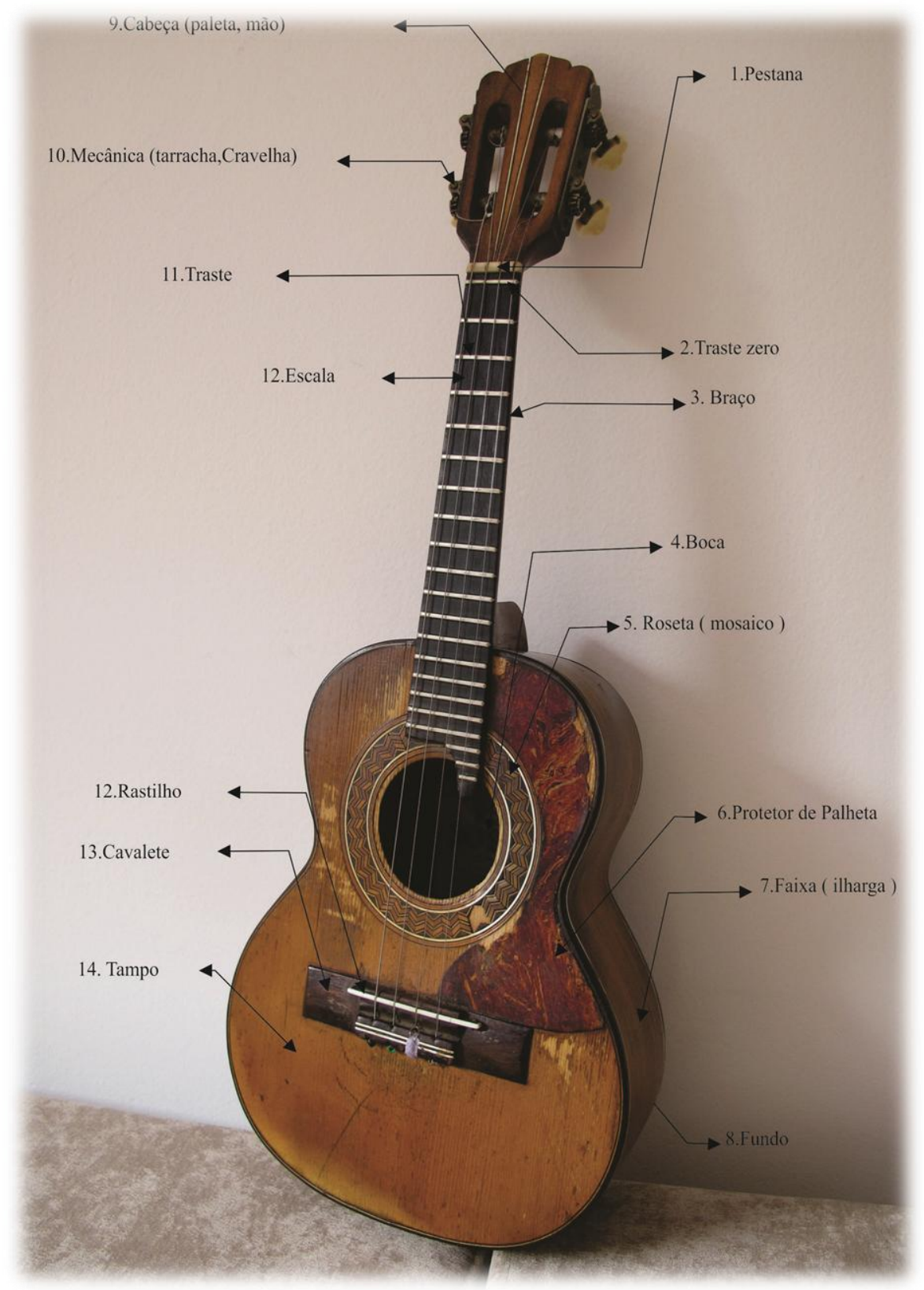




\section{1 - Contribuições ameríndias, portuguesas e africanas}

A música brasileira é formada, basicamente, pelo resultado das trocas sociais advindas de transferências culturais de proveniência ameríndia, europeia e africana. No livro Musicologia, Joseph Kerman faz referência à riqueza cultural que nasce da mistura dos elementos étnicos, especialmente nas Américas:

Charles Louis Seeger, em um de seus ensaios mais impressionantes, retrata as Américas como um grande laboratório cultural. Sonho de qualquer etnomusicólogo para o estudo da aculturação musical. Os conquistadores e colonizadores trouxeram com eles sua própria arte e música popular colocando-as em confronto com a música tradicional dos índios (SEEGER apud KERMAN, 1987, p. 222).

A falta de informação a respeito da música que foi feita no Brasil nos primeiros trezentos anos após sua "descoberta" é elemento dificultador para quem se aventura em uma pesquisa sobre o assunto. Somente no século XIX foram feitos os primeiros registros documentais por viajantes europeus, como consta no livro Música Popular Brasileira, da folclorista Oneyda Alvarenga:

Este material, embora minguado, permitiu aos estudiosos do folclore nacional chegar às seguintes conclusões históricas básicas: nos tempos do Brasil colônia, (1500-1806), cada um dos elementos étnicos que concorreram em maior parte para a constituição do povo brasileiro (índios, portugueses, negros), possivelmente fazia sua música própria; com o século XIX, apareceram traços indicadores de uma originalidade nascente, mas incapazes ainda de motivar uma cor nacional inconfundível; só no último quartel do século XIX é que, fixando elementos até então incertos ou indecisos, a nossa música popular principia a definir-se como criação peculiar e representativa do povo brasileiro (ALVARENGA, 1950, p. 17).

Os aborígenes, primeiros habitantes do Brasil, nos deixaram sua herança musical, que é sentida, principalmente, nas manifestações folclóricas. Sua expressividade sonora é simples, porém possui muita importância na vida social e religiosa, como registra Oneyda:

A música dos aborígenes do Brasil, como qualquer música primitiva, foi e é essencialmente religiosa, ligada a cerimônias e a atividades de que dependia diretamente a vida da tribo: cantos e danças de guerra, de caça, de pesca, de invocação e homenagem às entidades sobrenaturais de que se consideravam dependentes, animais totens e espíritos, e finalmente de celebração dos fatos sociais, morte, doença, etc. (ALVARENGA, 1950, p. 18).

O canto sempre teve importância especial na vida social dos indígenas, a tal ponto que, se aprisionado, um índio-cantor em tempos de guerra, sua vida era poupada e também a de seus filhos, como observa Alvarenga: 
Dado esse valor espiritual da música, as tribos brasílicas cercavam de grande consideração os cantores de ambos os sexos. Locomoviam-se eles sem cuidado, mesmo por entre os inimigos e, se aprisionados na guerra, os vencedores não o sacrificavam nas cerimônias de antropofagia, gozando seus filhos da mesma imunidade (ALVARENGA, 1950, p. 19).

Conforme o que está registrado no livro Abecê de Folclore, de Rossini Tavares de Lima, as escalas usadas na música ameríndia são em geral de poucas notas. Na sua melodia, é constante o uso do intervalo de terça. Em alguns cantos, pode aparecer a terça menor, que lhes dá um caráter todo especial (LIMA, 1985, p. 79).

Sobre a construção simplória da música indígena, Oneyda Alvarenga complementa:

De âmbito melódico estreito, reduzia-se frequentemente a um recitativo monótono dentro de dois ou três sons apenas, e mesmo algumas vezes não passava de uma fala ritmada dentro de um som único. Preponderavam os instrumentos de percussão, especialmente os chocalhos de vários tipos, entre os quais assumia grande importância musical, e mesmo religiosa segundo alguns, o maracá, utilizado pelos pajés como meio de comunicação dos espíritos (ALVARENGA, 1950, p. 19).

O ritmo dos indígenas é simples, sem grandes modificações, sem grandes improvisações, como nos informa Rossini Tavares de Lima:

O ritmo é repetitivo, dinâmico, mas em geral simples, a palavra de ordem é resistência, pois costumam executá-lo um dia ou uma noite inteira. Ao término da apresentação musical, os participantes revelam um estado semelhante ao do transe (LIMA, 1985, p. 80).

Parece-me que essa resistência para tocar durante muitas horas ficou como herança em manifestações folclóricas brasileiras, como a Folia de Reis, e em manifestações musicais urbanas como o samba.

As diversas etnias indígenas nos deixaram uma grande variedade de instrumentos que são muito aproveitados em vários estilos da música brasileira: tambores feitos de tronco de árvore, flautas de vários tipos e tamanhos, trompas, buzinas, assobios, pios, reco-recos de bambu, guizos amarrados às pernas, berra-bois ou zumbidores, matracas e maracás (LIMA, 1985, p.80-81). "Essa foi a música que os primeiros missionários encontraram entre os aborígenes e trataram de substituir progressivamente pela música europeia" (ALVARENGA, 1950, p. 20).

De acordo com o livro Música Popular Brasileira, de Oneyda Alvarenga, Mário de Andrade considerou como de proveniência indígena os seguintes elementos: 
O chocalho, usado nas nossas orquestras de dança; a forma poético-musical, em que a cada verso de uma estrofe se segue um refrão curto; o cateretê e o cururu (danças); o nasal da voz cantada caipira (zonas rurais do centro do Brasil); a variedade de assuntos num canto em contraposição à predominância amorosa das cantigas de Portugal; os bailados (caboclinho e caiapós); e os ritos fetichistas (catimbó e pajelança) de inspiração ameríndia e com larga participação de música; o movimento oratório da melodia, coincidindo provavelmente com a influência do canto gregoriano, que os índios aprenderam com os padres (ANDRADE apud ALVARENGA, 1950, p. 21)

Os portugueses foram os primeiros representantes da contribuição europeia no Brasil. Nos trouxeram danças, a língua, a melancolia, os instrumentos cordofônicos, entre os quais o cavaquinho. É importante lembrarmos que, devido à troca de informações culturais que ocorreram na Europa, a bagagem cultural trazida pelos lusitanos possui traços culturais de todo o continente europeu. No livro Abecê de Folclore, Rossini Tavares de Lima enumera algumas contribuições trazidas pelos portugueses:

Recebemos, através dos portugueses, além do sistema harmônico tonal, melodia quadrada, dorme-nenês, rodas infantis, solfas de danças: vários romances ou rimances tradicionais, em tonalidade menor, compasso ternário e, às vezes, seis por oito; a fórmula rítmica de colcheia e duas semicolcheias, característica da música portuguesa e espanhola; instrumentos [...] como o triângulo, com o nome de "ferrinhos", a sanfona, a viola, o cavaquinho, a rabeca, o bumbo ou zabumba, [...] a caixa clara, o pandeiro, o adufe (LIMA, 1985, p. 83).

As danças Cana-Verde, Ciranda ou Cirandinha, a Dança do Ramalhão e a Chimarrita traduzem a mais direta influência portuguesa, já os festejos folclóricos, como Bumba-meu-boi, Reisados, Guerreiros, Marujadas, Pastorinhas, Folia de Reis, Jardineira e Pau-de-fita têm influências de várias partes da Europa (ibidem).

Oneyda Alvarenga enfatisa a predominância da contribuição portuguesa na formação da música brasileira:

Visto que foi pela colonização portuguesa que o Brasil começou a existir como nação e foi governado durante mais de três séculos por Portugal; visto que as duas outras raças que mais concorreram para a formação do homem brasileiro sofreram o predomínio e a influência do homem branco, é natural que coubesse aos portugueses a parte preponderante na constituição da nossa música (ALVARENGA, 1950, p. 25).

Na minha vivência musical pude observar que o músico de tradição afro-americana possui uma ginga muito desenvolvida, demonstrando, desde criança, facilidade com instrumentos de percussão. "Tal como entre os ameríndios, à música desses povos negros sempre coube também uma função social e religiosa" (ALVARENGA, 1950, p. 22). Aquele 
tempero jocoso no andamento, que quebra o quadradismo musical, veio da África, a facilidade de improvisar com diversas variações rítmicas está na veia do afro-descendente, como afirma Rossini Tavares de Lima:

Enquanto outros povos cantam em um ou no máximo dois registros, os negros da África apresentam em seu canto uma grande liberdade. Em consequência, a música africana surge como uma das mais variáveis e imprevisíveis do mundo. $\mathrm{O}$ cantor parece não respeitar regras ou modêlos. Brinca com a voz do grave ao falcete, intercalando grunhidos e gritos. [...] $\mathrm{O}$ estilo negro africano é sempre polirrítmico. Quando interpreta determinado rítmo o músico negro revela grande dose de fantasia. Na África Ocidental, principalmente, o material rítmico apresenta enorme complexidade e uma tendência heterométrica (LIMA, 1985, p. 82).

Os negros escravos que chegaram ao Brasil vieram de diversas tribos africanas e aqui foram misturados. Esse fato gerou uma diversidade cultural muito grande, entre a própria população negra, fomentando um enriquecimento ainda maior nos vários rítmos e danças. "O Brasil, que recebeu africanos de diferentes regiões, ficou com uma das músicas populares mais diversificadas do mapa" (SOUZA, 2003, p. 25).

Segundo Rossini Tavares de Lima, as culturas africanas que mais influenciaram a brasileira foram a Yorubá (ou Nagô) e a cultura Bantu :

Culturas que mais profundos traços deixaram no sentir, pensar, agir e reagir espontâneos das coletividades rurais e urbanas foram as Sudanesas, com o predomínio do Yorubá, e as Bantus, por intermédio dos negros de Angola, Congo e Moçambique (LIMA, 1985, p. 132).

Entre os instrumentos musicais da cultura Yorubá em mistura com as culturas Jejê (ou Daomeana) e a Angola-Conguesa, Rossini de Lima aponta, entre os membranofones, os atabaques "rum" (grande), "rumpi" (médio) e "le" (pequeno) e os "ilus" pernambucanos; entre os idiofones, o "agogô", o "conguê", o "afochê" e o "adjá"; e representando os aerofones, o "afoiê", pequena flauta já desaparecida (LIMA, 1985, p. 132).

Os instrumentos musicais que vieram para o Brasil com o povo Bantu, segundo Rossini de Lima, são os membranofones percussivos "tambu”, "candongueiro", “quinjengue”, "engome" ou "angoma" e "zambê"; o membranofone de fricção "cuíca" ou "puíta"; o cordofone de arco musical "berimbau" ou "urucungu"; o idiofone "marimba", etc (LIMA, 1985, p. 135).

Manifetações culturais como a capoeira (jogo de pernadas); as danças batuque, samba, jongo e lundu; as manifestações folclóricas Congada, Moçambique, Quilombo, Ticumbi, 
Maracatu, Maculelê; e até os cordões, ranchos e clubes carnavalescos possuem traços da cultura Bantu (LIMA, 1985, p. 136).

Do resultado de toda essa mistura étnica entre o aborígeno, o português e o africano, da troca mútua de costumes e traços culturais entre esses povos, surgiu a base para a formação de uma identidade própria da música brasileira.

Mas não foram só esses povos que contribuíram para a nossa formação musical. Temos referências da música francesa no nosso repertório infantil e contribuições espanholas, algumas da mesma fonte de heranças portuguesas, outras puramente espanholas, como as danças Fandango e Tirana (ALVARENGA, 1950, p. 26).

A chegada do século XIX trouxe para o Brasil as influências de danças procedentes de vários países da Europa, além de traços das músicas cubana e argentina. Essas contribuições foram marcantes na formação de vários gêneros musicais brasileiros, onde o cavaquinho se faz presente, como veremos a seguir.

\section{2 - Chorando pelos dedos}

O Rio de Janeiro, na segunda metade do século XIX, passava por grandes mudanças sociais, políticas, econômicas e culturais. É nessa época que nasce o choro: gênero musical onde o cavaquinho é indispensável e que tem como influências predominantes a dança europeia polca e o ritmo africano lundu. A valsa, o schottisch, a mazurca e a quadrilha, são outras contribuições culturais vindas da Europa. A habanera cubana e o tango argentino também chegaram ao Brasil e ajudaram a "temperar" a nossa música. "Recolhi uma vez uma marchinha para sanfona, dançada em bailes rurais de certa zona de Minas Gerais, que não passava de leve acomodação de um velho tango argentino" (ALVARENGA, 1950, p. 26).

O pesquisador André Diniz, em seu livro Almanaque do Choro, contribui para a compreensão do surgimento do choro:

As interpretações dos gêneros estrangeiros da época - como a polca, a valsa, o schottisch, a quadrilha - fizeram nascer um jeito "brasileiro" de tocar. O choro do século XIX surgiu como uma maneira de frasear, ou seja, um estilo de executar os gêneros europeus. A influência européia, portanto era clara, mas não foi única. $\mathrm{O}$ lundu era o outro rio que iria desembocar no novo ritmo (DINIZ, 2008, p. 17). 
Ricardo Cravo Albin emite seus conhecimentos sobre a polca, sua fusão com o lundu e com instrumentos do choro:

Dança de salão em compasso binário, geralmente em tom maior e andamento alegreto, originária da Boêmia (hoje República Tcheca). Chegou a Paris em meados da década de 1830, difundindo-se daí para todo o mundo ocidental, onde se tornou a primeira dança de salão. Chegou ao Brasil na noite de 03 de julho de 1845 , quando foi apresentada pela primeira vez num teatro carioca. O sucesso foi tal que três dias depois, os dançarinos abriram um curso de polca. Os elementos da polca fundiram-se com os afrobrasileiros do lundu e, na aceitação da rítmica daí resultante pelos conjuntos populares de flauta, cavaquinho e violão, deram origem a gêneros como o tango brasileiro ${ }^{48}$, o maxixe e, posteriormente, o próprio choro (ALBIN, 2006, p. 595).

Sobre a difusão da polca, o bandolinista e pesquisador Jorge Cardoso Moura esclarece:

A execução da polca se deu por meio de pianistas populares, denominados de forma pejorativa de "pianeiros", em salões da elite, juntamente com operetas e revistas, na privacidade dos lares pelas pianistas e pelos conjuntos de populares, denominados trios ou ternos formados por violão, cavaquinho e flauta (MOURA, 2011, p. 64).

O pianista e ensaísta José Miguel Wisnik aponta para uma possível influência de

Chopin no processo de nascimento do choro:

A polca requebrada pelo maxixe, colorida pelos lances da instrumentação chorística, trabalhada pela manha dos pianeiros populares e do piano chopiniano.[...] Combinavam na verdade os batuques da música negra, os tímbres instrumentais da música urbana (ressoando a baixaria do violão, a batida do cavaquinho, os voos fulgurantes da flauta), as cascatas melódicas e os pulos-do-gato dos pianeiros cariocas, com um sentido construtivo límpido e saborosamente pianístico aprendido nas mazurcas, prelúdios, estudos e valsas de Chopin (WISNIK, 1982, p. 08).

Os conjuntos populares, citados acima, também eram conhecidos como grupos de "pau e corda", uma referência à flauta, que era feita de ébano (madeira especial), e às cordas dos demais instrumentos acompanhantes, cavaquinho e violão.

Geralmente o único que sabia ler a partitura, o flautista, tinha papel importantíssimo nos grupos de choro, pois incentivava o gosto pelo choro aguçando as qualidades musicais dos acompanhadores de ouvido. Era um hábito o flautista desafiar, brincar, e às vezes fazer cair, com suas "armadilhas" harmônicas, o cavaquinista e o violonista. O calor das rodas de choro, as malandragens nas execuções, a provocação dos instrumentistas

\footnotetext{
${ }^{48}$ Apontado por musicólogos como uma variante mais bem cuidada do maxixe, constituiu o gênero menos popular e por isso mesmo de trajetória mais curta. A maioria dos autores concorda que este gênero seja uma adaptação da habanera introduzida no Brasil pelas companhias de teatro musicado europeu, à qual se incorporaram elementos da polca e do schottisch. O responsável pela sua criação foi o carioca Henrique Alves de Mesquita e não Ernesto Nazareth, como muitos pensam (TINHORÃO, 2013, p. 113-15).
} 
solistas - tudo colaborava para imprimir ao gênero sua tônica de liberdade e improviso (DINIZ, 2008, p. 15).

Henrique Cazes acrescenta que se tivesse que apontar uma data para o início da história do choro, não hesitaria em dar o mês de julho de 1845, quando a polca foi dançada pela primeira vez no teatro São Pedro, no Rio de Janeiro (CAZES, 1998, p. 17).

Tão importante quanto a polca, na formação do choro, foi o lundu. Dança africana, trazida pelos escravos, como observa André Diniz em outra publicação, Almanaque do Samba:

De origem africana, mais precisamente da região de Angola e do Congo, o lundu foi trazido para o Brasil pelos escravos no fim do século XVIII. Caracteriza-se pelo canto e pela dança em que o alteamento dos braços, com o estalar dos dedos e a umbigada - encontro dos umbigos dos homens e das mulheres - são acompanhados por palmas (DINIZ, 2010, p. 20).

O lundu era tocado e dançado nas áreas rurais, no cultivo da cana-de-açúcar, com muita percussão, palmas e refrãos melódicos. Ao chegar à cidade, no século XIX, o lundu foi muito apreciado por todos, independentemente do nível sócio-econômico, como registra André Diniz:

Em terras brasileiras a dança do lundu foi cultivada por negros, mestiços e brancos. No século XIX, o lundu vira lundu-canção, sendo apreciado nos circos, nas casas de chope e nos salões do Império. Acabou por tornar-se o primeiro gênero musical a ser gravado no Brasil ("Isto é Bom", de Xisto Bahia, gravado na voz de Baiano em 1902, pela Casa Edson) (DINIZ, 2010, p. 20-21).

Nossa bibliografia musical faz referência a um bandolinista que tocava no início do século XIX, "por pontos, o doce lundu, chorado", demonstrando a forte ligação do lundu com o choro (DINIZ, 2008, p. 17).

Os conjuntos de "pau e corda", sob a influência do lundu, imprimiam uma maneira mais balançada, mais sincopada de tocar a polca. Dessa mistura polca-lundu, com um tempero da habanera cubana, surge o maxixe, dança e gênero musical urbano, bem próximo do choro. Estava aí nascendo o que mais tarde seria chamado de choro, que foi, antes de tudo, uma maneira de tocar. No livro Pequena História da Música Popular Brasileira de José Ramos Tinhorão, encontramos a seguinte citação:

Transformada a polca em maxixe, via lundu dançado e cantado, através de uma estilização musical, efetuada pelos músicos dos conjuntos de choro, para atender ao gosto bizarro dos dançarinos das camadas populares da Cidade Nova ${ }^{49}$ (TINHORÃO, 2013, p.78).

\footnotetext{
${ }^{49}$ Sobre a chamada Cidade Nova, falaremos no item 2.3, "O Samba da Minha Terra”.
} 
O pesquisador Marcos Napolitano, em seu livro História Cultural da Música Popular, faz menção às influências culturais encontradas no choro:

Nele estavam presentes o pensamento contrapontístico do barroco; o andamento e as frases musicais típicas da polca; os timbres instrumentais suaves e brejeiros, levemente melancólicos e a síncopa que deslocava a acentuação rítmica "quadrada", dando-lhe um toque sensual e jocoso (NAPOLITANO, 2005, p. 44).

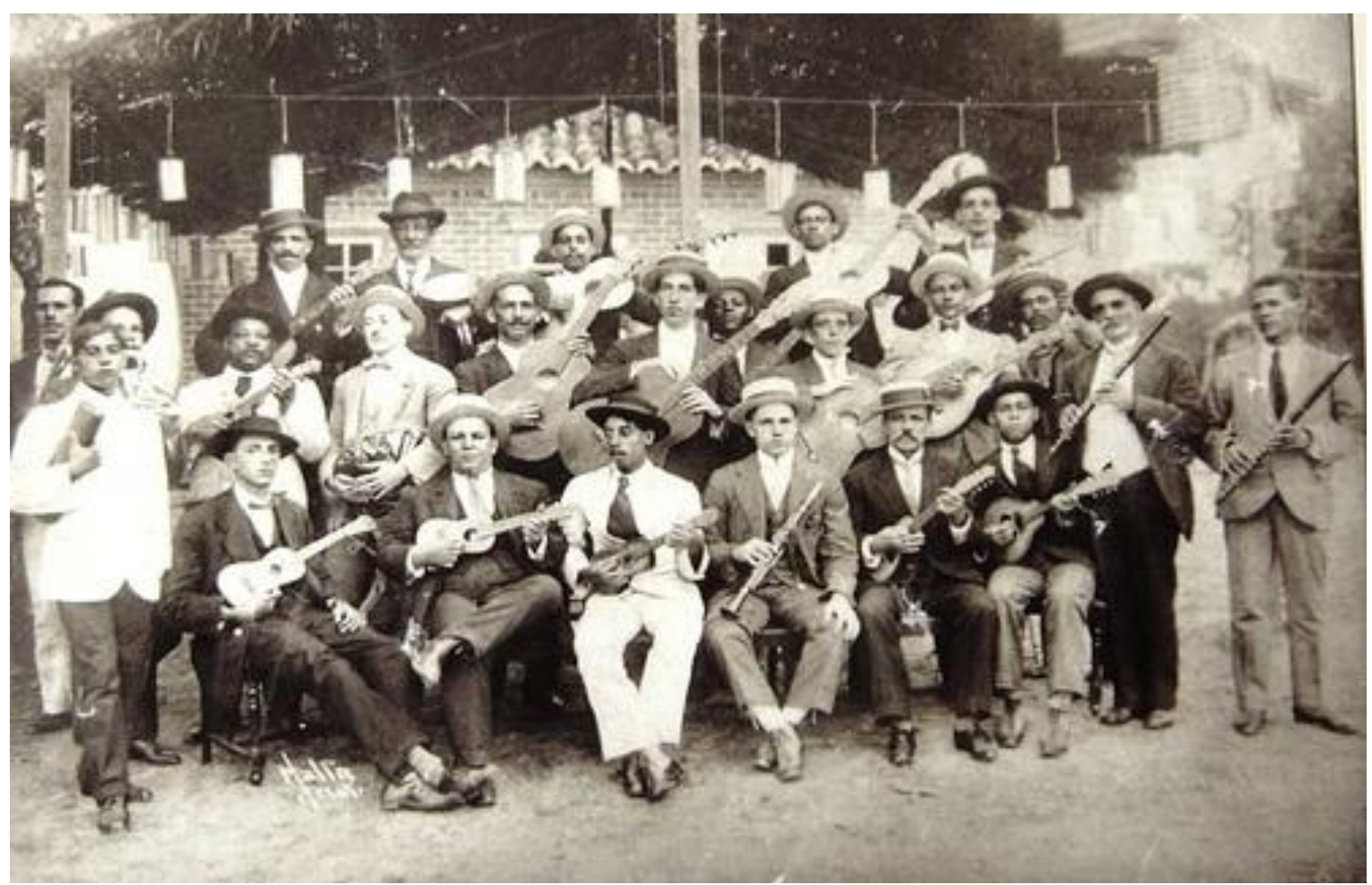

Figura 24 - Grupo de choro do início do século $\mathrm{XX}^{50}$.

$\mathrm{Na}$ foto da figura 24, podemos observar vários chorões do início do século $\mathrm{XX}$ empunhando seus instrumentos, entre os quais cavaquinhos, violões, pandeiro, ganzá, clarinete, flautas de madeira e um bandolim nas mãos do primeiro músico sentado do lado direito da foto. Também sentado, ao lado do bandolinista, vemos um músico de bigode com um cavaquinho de oito cordas. É um mandolinetto, instrumento desaparecido das rodas de choro, que tem as cordas e a afinação de bandolim e corpo de cavaquinho. Em pé, ao lado dos dois flautistas, um músico segura uma bandurria, instrumento semelhante ao bandolim, porém maior, que também entrou em desuso.

\footnotetext{
${ }^{50}$ Disponível em: http://www.pensario.uff.br/audio/1870-aproximadamente-1870-nasceu-choro-rio-de-janeiro. Acesso em: 19/03/2015.
} 
A partir da década de 1920 o conjunto de "pau e corda" já contava com mais um violão de sete cordas (que fazia as "baixarias", linhas de baixo contrapontísticas) e na percussão tinha o apoio do pandeiro (FILHO, 2009, p. 20). Além da flauta, surgem novos instrumentos solistas como o sax, o clarinete, o bandolim e o trompete, entre outros. Esse tipo de conjunto passaria a ser conhecido como Regional de Choro. O nome "Regional" teria surgido em carnavais do início do Século XX quando essa formação de músicos atuava usando roupas típicas de regiões brasileiras, como por exemplo, as do Nordeste (MOURA, 2011, p. 83).

O nome Regional se originou de grupos como Turunas Pernambucanos, Voz do Sertão e mesmo Os Oito Batutas, que na década de 1920 associavam a instrumentação de violões, cavaquinho e algum solista a um caráter de música regional (CAZES, 1998, p. 83).

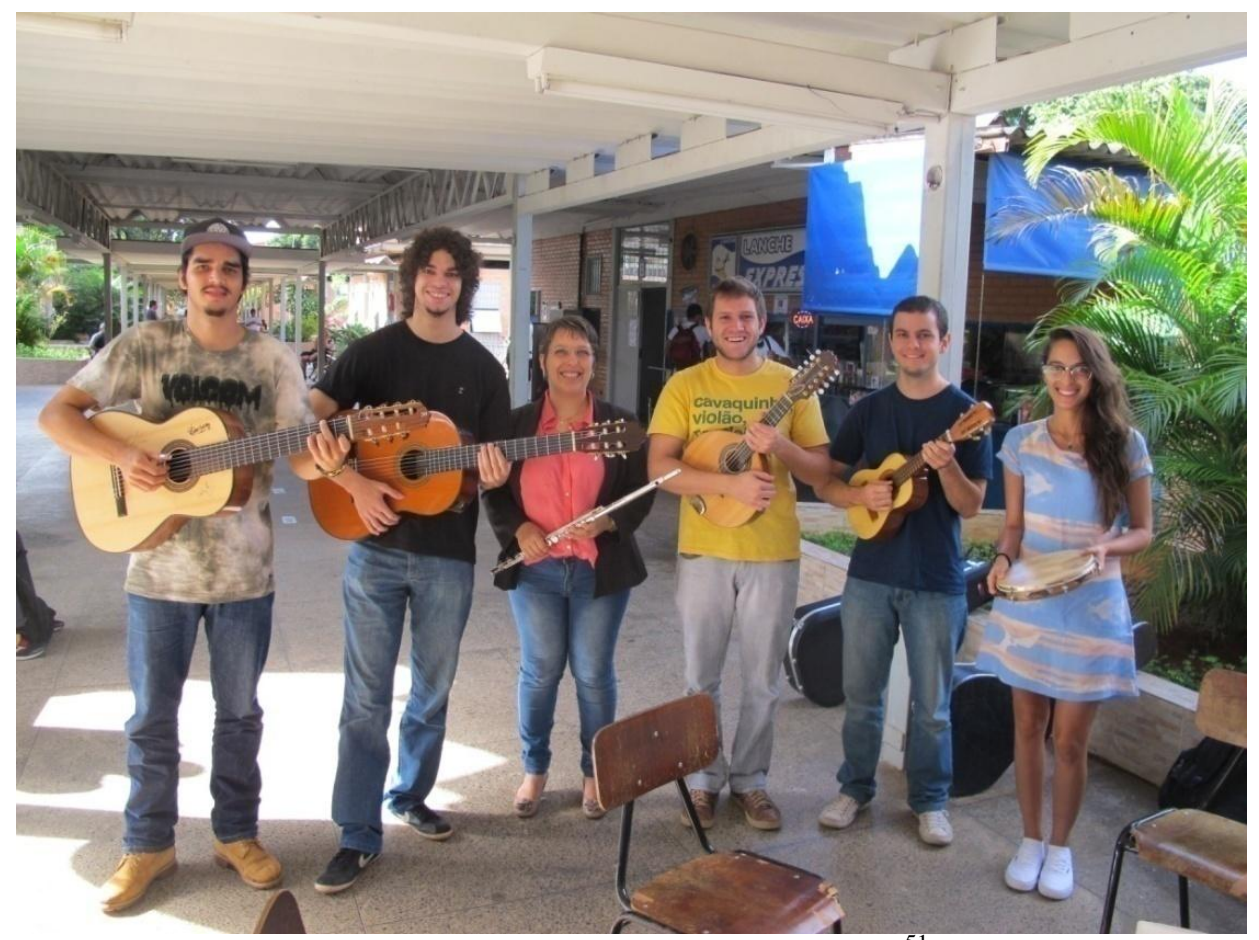

Figura 25 - Instrumentos do Regional ${ }^{51}$

$\mathrm{Na}$ foto acima temos a formação de Regional que é considerada clássica. Da esquerda para a direita podemos ver o violão de 7 cordas (Kaio Graco), o violão de 6 cordas (João Vitor), a flauta (Diana Mota), o bandolim (Vitor Angeleas), o cavaquinho (Guilherme Maia) e o pandeiro (Isabella Pina).

\footnotetext{
${ }^{51}$ Foto tirada por mim dos músicos da Roda de Choro da Escola de Música de Brasília, em 16/04/2015. Um leitor mais observador deve ter reparado que o bandolim de Vitor Angeleas é de dez cordas, instrumento que vem ganhando a preferência de bandolinistas brasilienses.
} 
Com a explosão da Era do Rádio, os Regionais de Choro ganharam grande espaço no mercado musical. Cada Emissora contratava um Regional que, com sua versatilidade, acompanhava os mais diversos cantores. E, comparado a uma orquestra, era um conjunto que custava pouco por seu número reduzido de músicos. Cada Regional tinha um cavaquinho e esse fato fez com que o instrumento ganhasse uma "cara" profissional. Surgiram vários empregos para cavaquinistas (CAZES, 2012).

O cavaquinho no choro tem função de instrumento harmônico e também de instrumento solista (que faz a linha melódica). Dessa forma, podemos ter formações de conjunto de choro (regional) com dois cavaquinhos: um solista e um acompanhador (cavaco centro). Este último, no palco, se posiciona entre os violões e o pandeiro, dando apoio rítmico e harmônico aos violões, ao mesmo tempo, que interage ritmicamente com o pandeiro.

Numa roda de choro sem cavaquinho de centro, mesmo com vários violões, se sente a falta do ritmo balançado e alegre do pequeno instrumento, como confirma o cavaquinista Henrique Cazes:

Até hoje, se tocarmos dois violões e pandeiro, os sons não se compactam. Só quando entra o cavaquinho é que essa base, tão usual na música brasileira, passa a funcionar satisfatoriamente (CAZES, 2012).

Aproveito para citar dois nomes de acompanhadores de cavaquinho que ficaram para a história e nos deixaram suas experiências em registros fonográficos: Canhoto e Jonas.

Waldiro Frederico Tramontano ou Canhoto (1908-1987) desenvolveu levadas rítmicas que até hoje estão embutidas no subconsciente cultural de todos os cavaquinistas ligados ao choro e também ao samba. No livro Choro do Quintal ao Municipal, encontramos a seguinte citação:

Waldiro Frederico Tramontano, o Canhoto, era carioca, nascido em 1908. Tocava cavaquinho virado para o lado oposto do usual e, consequentemente, palhetava as cordas de baixo para cima. Acabou desse jeito criando um estilo que, embora extremamente discreto, era muito marcante. Apesar de mais tarde liderar um conjunto que levava seu nome, pouco se arriscou como solista (CAZES, 1998, p. 84).

Jonas Pereira da Silva (1934-1997), apesar de ter sido excelente solista, ficou famoso com seu cavaquinho de centro no Conjunto Época de Ouro, fundado por Jacob do Bandolim.

Em entrevista, Jorginho do Pandeiro, integrante do referido conjunto, me revelou: 
O Jacob dizia: "ele é o único cavaquinho que tem uma palhetada para cada música." Para cada choro ele inventava uma palhetada que dava um apoio bárbaro... ele era muito bom! Ele não adiantava, não atrasava... me dando apoio (SILVA, 2014).

Já ouvi choro acompanhado por bandolim, que tem o timbre semelhante ao do cavaquinho e, em minha opinião, não é a mesma coisa. O cavaquinho no acompanhamento de choro é insubstituível. Muitos bandolinistas tocam cavaquinho com afinação de bandolim e assim se inserem nas rodas de choro e no mercado de trabalho como cavaquinistas de centro.

O bandolinista pernambucano Luperce Miranda também tocou cavaquinho:

Luperce gravou bastante de cavaquinho, sendo seu centro facilmente reconhecido pela afinação de bandolim [...] como podemos ouvir na série de gravações que fez com Pixinguinha e Tute na virada da década de 1930 (CAZES, 1998, p. 67).

Vimos que o cavaquinho está presente desde o início da formação da nossa música brasileira, e com o choro não é diferente: o cavaquinho está lá, como instrumento solista e como instrumento acompanhador.

\section{3 - O Samba da minha terra}

O outro gênero musical onde o cavaquinho se tornou instrumento indispensável é o samba, uma das principais manifestações culturais do nosso país e patrimônio da humanidade.

O samba, ou samba moderno, ou samba de raiz, que conhecemos nos dias de hoje, sofreu a influência de outros ritmos e danças brasileiros, como o lundu, a modinha, o maxixe e o próprio choro. Suas origens estão nas danças de raízes africanas, chamadas batuque, que eram praticadas por escravos negros na zona rural no século XIX. Num sentido mais abrangente, qualquer manifestação que reunisse canto, dança e uso de instrumentos dos negros era conhecida como batuque. "Esse era então um termo genérico para designar festejos. $\mathrm{O}$ sentido amplo permaneceu na literatura colonial até o início do século $\mathrm{XX}$, quando a palavra samba passou a suplantar a palavra batuque” (DINIZ, 2010, p. 15).

Na prática do batuque era comum a formação de uma roda feita pelos integrantes, que dançavam, batiam palmas e cantavam no estilo responsório, em que um ou mais solistas cantavam a melodia depois repetida pelo coro. No meio da roda, um integrante se apresentava 
e fazia uma demonstração de suas habilidades com a dança. Em seguida, se dirigia a um dos participantes, em geral do sexo oposto, e lhe dava uma umbigada que tinha a conotação de um convite para dançar. Os dois podiam fazer uma coreografia de par separados antes do convidado substiuir o primeiro dançarino. "Se pode admitir que a palavra samba tem sua origem no termo semba , que na língua africana bantu significa barrigada" (NIN, 1990, p. 30).

Sobre a umbigada, o escritor Carlos Sandroni nos esclarece, em seu livro Feitiço Descente:

A umbigada é o gesto pelo qual um dançarino designa aquele que irá substituí-lo. [...] Os pesquisadores atribuíam tanta importância à umbigada como gestos característicos de certas danças profanas afro-brasileiras, que em 1961, Edson Carneiro cunhou a expressão "samba de umbigada" para servir como designação geral delas. Para Carneiro, qualquer dança que apresentasse os traços descritos acima (presença da umbigada ou seus sucedâneos, disposição em círculo dos participantes-expectadores, canto responsorial, palmas, etc.) faz jus à designação, quer os envolvidos ou os observadores que a descreveram a chamem de "samba" de "coco" ou de "lundu", quer não haja nenhum nome consignado (SANDRONI, 2001, p. 87).

Assim a palavra samba ganha um significado de festa, reuniões de afro-descendentes em torno de seus instrumentos, desenvolvendo suas danças em manifestação tipicamente rural. Essa expressão cultural, o samba do interior, acontecia concomitantemente em várias partes do Brasil e o cavaquinho, instrumento festivo que é, já se fazia presente, como registra Guilherme de Melo em seu livro A Música no Brasil:

Na Bahia chama-se "samba", no Rio de Janeiro se denominava "chiba", no Estado de Minas "cateretê", e nos estados do sul "Fandango". Trata-se de uma dança de roça ao ar livre, em que por instrumentos entram o violão, a viola de arame (aço), o cavaquinho, sob a toada dos quais se canta e se sapateia ao ritmar das palmas, dos pratos e dos pandeiros (MELO, 1908, p. $31)$.

Segundo José Ramos Tinhorão, no dia 03 de fevereiro de 1838, a palavra samba aparece no jornal humorístico $O$ Carapuceiro, em Pernambuco, por Frei Miguel do Sacramento Lopes Gama (TINHORÃO, 2008, p. 86). Luis da Câmara Cascudo, em seu Dicionário do Folclore Brasileiro, na página 630, citou o referido jornal e o verso com a palavra samba:

Aqui pelo nosso mato Que estava então mui tabamba

Não se sabia outra coisa

Senão a dança do samba 
As práticas da umbigada foram incorporadas pelo samba de roda baiano, que por sua vez teve influência direta no samba como o conhecemos hoje, o samba carioca, ou samba de raiz. Então, o samba nasceu na Bahia e foi para o Rio de Janeiro, onde ganhou nova roupagem. O samba de raiz nasceu no Rio de Janeiro.

A abolição da escravatura, a decadência econômica da agricultura de cana de açúcar no Nordeste, a crise do café no Vale do Paraíba provocaram uma migração de ex-escravos para o Rio de Janeiro, então capital do Brasil, em busca de trabalho. E ainda o fluxo de ex-combatentes negros da Guerra de Canudos, que haviam lutado contra Antônio Conselheiro e ganharam o direito de morar no Rio, somados aos estrangeiros que vinham tentar a vida por aqui e aos nordestinos fugindo da sêca, fizeram a população da capital passar de quinhentos mil para um milhão de habitantes entre os anos de 1890 e 1917 (NIN, 1990, p. 30).

A população negra, em sua maioria formada por baianos, se concentrou em cortiços paupérrimos na região da Central do Brasil e da Cidade Nova, nas cercanias da extinta Praça Onze, onde hoje é o Sambódromo Darcy Ribeiro, e formaram uma comunidade: A Pequena África. Sobre o assunto André Diniz registrou em seu livro Almanaque do Samba:

Essa população de negros passou a residir na Gamboa, Saúde e Santo Cristo. Com as reformas urbanísticas realizadas pelo prefeito Pereira Passos no Centro da cidade, sobretudo na zona portuária e imediações, os baianos tiveram que subir ao longo da avenida Presidente Vargas, transformando os antigos luxuosos casarões da burguesia em "modernos" cortiços. Nas imediações das ruas Visconde de Itaúna, Senador Euzébio, Marquês de Sapucaí e Barão de São Félix residiam os negros da Cidade Nova, local chamado pelo compositor Heitor dos Prazeres de "Pequena África" (DINIZ, 2010, p. 26).

Com os negros baianos vieram as suas danças, seus batuques, suas rodas de capoeira e pernadas e o Samba de Roda Baiano, que passaram a ser praticados com frequência nas ruas, nas praças do novo bairro e nas famosas festas nas casas das "tias baianas", que eram senhoras gordas quituteiras, que davam festas para comemorar as datas do calendário do candomblé (ALBIN, 2003, p. 66).

Os festejos ou pagodes das tias baianas eram um desfile de estilos da musicalidade afro-brasileira. Da sala de visitas ao quintal, os frequentadores se deparavam com rodas de choro e danças de pares enlaçados; com rodas de samba e danças de pares separados; e ainda com rodas de capoeira, umbigadas e pernadas ao som de atabaques do candomblé. Dentre as tias baianas, a mais festejada era Hilária Batista Almeida, a Tia Ciata, que segundo Mário de Andrade, passava o dia de violão no colo inventando melodias amaxixadas (ANDRADE apud 
SANDRONI, 2001, p. 133). Dentre os frequentadores dos pagodes de Tia Ciata destacamos os músicos Pixinguinha, João da Baiana, Donga e Heitor dos Prazeres, que tocava cavaquinho.

Os escritores Marília T. Barboza da Silva e Arthur L. de Oliveira Filho têm uma descrição peculiar das festas de Tia Ciata:

Festa de Preto na Tia Ciata - Na sala da frente o baile comia solto, um crioulão alto com cara de criança tocando uma flauta que Deus me livre! Esse menino Pixinguinha vai longe, que capeta nessa flauta! Com pose e maestria Donga olhava as mulatinhas enquanto secundava os trinados, maltratando os bordões do pinho novo. China ensaiava uma terça. E um escuro com calombo nas costas centrava no cavaquinho. Eta ferro! Pares enlaçados.

$\mathrm{Na}$ outra ponta do corredor, tão distante que nem interferia, partido alto seguia rasgado. João da Baiana de prato e faca na mão raiava a clula, Tia Perciliana sorrindo orgulhosa, Heitor dos Prazeres machucando o cavaco. Um grupo de negros cercava os músicos na maior animação, todo mundo envolvido pelo rítmo nativo. Baianas enchendo pratos de comida, ô que cheirinho bom, a pinga pra rebater e inspirar.

Lá no fundo do quintal, entre as árvores, tambores batucando, árvore e tambor, África renascida em plena capital federal, a roda, o batuque, palmas e suor, um casal descalço batendo os pés na terra e negaceando os corpos, que se encontravam finalmente na umbigada fatal" (SILVA \& OLIVEIRA FILHO, 1981, p. 17).

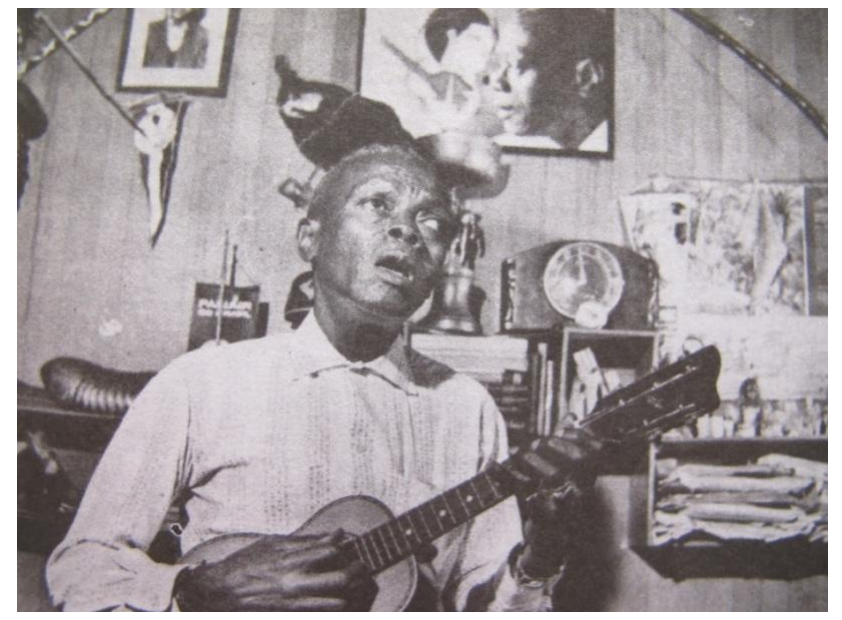

Figura 26 - Heitor dos Prazeres, cavaquinista, compositor e pintor,com um cavaquinho de cinco cordas $^{52}$.

Um trecho do livro O Mistério do Samba, do antropólogo Hermano Vianna, traz uma citação de Ari Vasconcelos que sugere uma parcela de contribuição cigana na construção do samba carioca:

\footnotetext{
${ }^{52}$ Disponível em: http://blogln.ning.com/profiles/blogs/centenario-de-assis-valente. Acesso em: 19/04/2015.
} 
Ari Vasconcelos aponta, entre os músicos que participavam das rodas de samba de Tia Ciata, o cigano Saudade. Aliás, ainda segundo Ari Vasconcelos, os ciganos não tiveram papel secundário na invenção do rítmo nacional brasileiro: Pixinguinha e João da Baiana me revelaram que havia um grupo de compositores, cantores e músicos ciganos que cultivavam o samba com grande maestria e que trouxeram também uma contribuição importante, talvez mesmo decisiva, ao gênero (VASCONCELOS apud VIANNA, 2012, p.112).

Leandro Narloch, em seu livro Guia Politicamente Incorreto da História do Brasil, também se refere à Tia Ciata e suas festas, reduto do nascimento do samba carioca:

Negra baiana que migrou para o Rio de Janeiro ainda no século 19, Ciata vendia doces vestindo turbante e saia do candomblé. Era a típica figura que inspirou a ala das baianas do desfile das escolas. À noite e nos fins de semana, músicos, políticos e intelectuais, jornalistas e amigos iam para o samba na casa dela - até então, "samba" significava um evento, uma festa e não um tipo de música. O novo estílo saiu da criatividade daquele grupo de amigos (NARLOCH, 2011, p. 147- 48).

Nas reuniões na casa de Tia Ciata nasceu o samba Pelo Telefone, dos compositores Donga (Ernesto dos Santos) e Mauro de Almeida, jornalista conhecido como Peru dos Pés Frios. Em 1917, Pelo Telefone foi gravado na voz de Baiano (Manoel Pedro dos Santos, 1887-1944) e tornou-se febre no carnaval. "É a partir de então que a palavara "samba"entra no vocabulário da música popular" (SANDRONI, 2001, p. 17). O historiador André Diniz acrescenta:

O samba carnavalesco, nome que Donga e Mauro deram ao gênero de sua composição, entrou para a história como precursor do gênero. A partir daí, o termo ganhou intensa popularidade e, em apenas algumas décadas, passaria a ser identificado como símbolo da musicalidade brasileira. [...] Muitas vozes acusaram Donga de ter se apropriado de uma criação coletiva cantada na casa da Tia Ciata (DINIZ, 2010, p. 34-35).

Antes da gravação, em 1916, Donga foi à Biblioteca Nacional e registrou Pelo Telefone em seu nome, fato que gerou polêmica para o resto de sua vida. Porém, o primeiro registro da autoria de um samba foi um marco rumo ao profissionalismo e ao reconhecimento dos compositores (DINIZ, 2010, p. 36).

Hermano Vianna concorda com a criação coletiva da música Pelo Telefone e registra o "mal estar" que a polêmica gerou entre os sambistas pioneiros:

Pixinguinha e Donga eram frequentadores da casa de Tia Ciata, na Praça Onze, endereço importantíssimo para o nascimento do samba carioca. Foi numa das noitadas musicais na casa dessa tia baiana que foi composto, coletivamente, o samba Pelo Telefone, que acabou entrando para a história como o primeiro samba registrado (como composição de Donga - um golpe 
que rendeu muitas desconfianças e até inimizades entre os sambistas pioneiros) (VIANNA, 2012, p. 112).

O samba feito no Rio de Janeiro de 1917 até o final da década de 1920, foi considerado um samba amaxixado, muito próximo do maxixe, o samba-maxixe, mais cadenciado. O samba que nasceu no bairro do Estácio de Sá, no início dos anos 1930, era o autêntico samba carioca, mais acelerado, mais balançado, mais sincopado, mais picotado; era o samba batucada, o samba de raíz, o samba que conhecemos hoje (SANDRONI, 2001, p. 17).

Tarik de Souza, em seu livro Tem Mais Samba: Das Raízes à Eletrônica, ilustra a passagem do samba amaxixado para o samba do Estácio:

Num diálogo de bambas fomentado por ele e reproduzido no livro As Escolas de Samba do Rio de Janeiro (Lumiar, 1996), o historiador Sérgio Cabral assegura que Donga teria citado como exemplo de samba seu "Pelo Telefone". Ismael Silva (1905-1978), que chamou a composição do outro de maxixe, rebateu com "Se Você Jurar". Ao que Donga retrucou, "isso não é samba, é marcha". E Ismael criaria a onomatopéia "bum bumpaticumbumprugurundum", que encerrava o assunto, definindo o compasso inovador do samba criado pela turma do Estácio, remodelando o samba inicialmente amaxixado de Donga, Sinhô, Heitor dos Prazeres e companhia (SOUZA, 2003, p. 33).

Seja nas danças africanas das roças, o batuque, seja nas casas das Tias Baianas, nas ruas da Cidade Nova, com o samba amaxixado, ou no Estácio, com o samba do malandro carioca, o cavaquinho esteve sempre presente, ajudando, com seu apoio rítmico e harmônico, a trilhar o caminho da desenvoltura do samba, fazendo a ligação entre os instrumentos de percussão e a harmonia. "Como já dizia o antigo samba: Samba sem cavaquinho não é samba. E eu acrescento: a música do Brasil, sem o cavaquinho, seria muito menos interessante" (RABELLO apud DINIZ, 2008, p. 72).

Paulinho da Viola, na primeira estrófe do seu samba Argumento, faz uma crítica a possíveis mudanças em relação aos instrumentos usados no samba, que ele próprio tinha observado. E confirma que no samba tem que ter cavaquinho:

Tá legal, eu aceito o argumento

Mas não me altere o samba tanto assim

Olha que a rapaziada está sentindo a falta

De um cavaco, de um pandeiro e de um tamborim (VIOLA, 1976) 


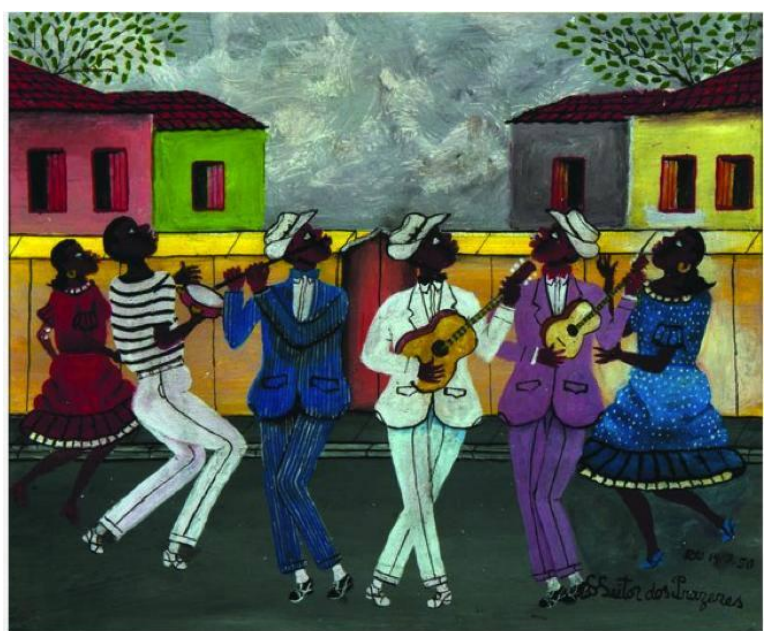

Figura 27 - Roda de Samba. ${ }^{53}$ Óleo de Heitor dos Prazeres

A pintura acima, de Heitor dos Prazeres, retrata uma prática importante da nossa música brasileira, o samba feito na rua. Podemos ver, da esquerda para a direita, uma dançarina, um pandeirista, um flautista, um violonista, um cavaquinista e outra dançarina. Nota-se que o artista quer mostrar a noção de movimento que existe na cena, de modo a transparecer que estão todos tocando, cantando e dançando. O nosso cavaquinho está presente na tela, reafirmando a importância do instrumento no samba.

Os compositores João Bosco e Aldir Blanc, em seu samba Kid Cavaquinho, mostram a ligação do cavaquinho com o samba e como esse instrumento é influente na sociedade amante do samba, a ponto de mesclarem situações do quotidiano do sambista com o próprio instrumento. Os dois primeiros versos sugerem que um cavaquinho, ao lado de instrumentos de percussão, já é o bastante para se tocar um bom samba. Em seguida, os autores fazem comparações que mostram a força do cavaquinho.

Oi que foi só pegar no cavaquinho

Prá nego bater.

Se eu contar o que é que pode um cavaquinho

Os "home" não vai crer

Quando ele fere, fere firme, dói que nem punhal

Quando ele invoca, até parece um pega na geral

Genésio! A mulher do vizinho sustenta aquele vagabundo

Veneno é com o meu cavaquinho

Pois se eu to com ele encaro todo mundo

Se alguém pisa no meu calo

Puxo o cavaquinho pra cantar de galo (BOSCO \& BLANC, 1982)

53 Disponível em: http://temasdeartecontemporanea.blogspot.com.br/2013/09/heitor-dos-prazeres-um-homemdo-povo.html. Acesso em: 19/04/2015. 
Na minha leitura, os versos "Se eu contar o que é que pode um cavaquinho, os "home" (a polícia) não vai crer", fazem referência à repressão que o samba sofreu com a discriminação social, já que é uma manifestação cultural que nasceu das camadas menos favorecidas, economicamente falando. Seguindo, nos versos: "Quando ele fere, fere firme, dói que nem punhal" e "Quando ele invoca, até parece um pega na geral" ${ }^{\text {"54 }}$ o cavaquinho aparece simbolizando um instrumento de guerra, representante de uma parte da sociedade que sempre esteve à margem. "O samba era proibido" (VIANNA, 2012, p. 114), "mesmo assim venceu, formou suas escolas e deslumbrou patrícios e estrangeiros" (EFEGÊ, 1980, p. 122).

No começo do século XX, o cavaquinho aparecia em duas situações na música popular: uma era a parte mais séria, mais musical, os grupos de choro que foram surgindo com grandes solistas e grandes compositores. E a outra era a parte mais divertida, da bagunça, dos blocos que se organizavam para brincar o carnaval, para fazer as festas de rua, as festas de padroeira. Esses blocos foram ficando importantes e se transformaram nas Escolas de Samba onde o cavaquinho sempre teve um papel importantíssimo, de liderança. Foi ele o diapasão da Escola, quem deu o tom, a harmonia, quem conduziu o canto das pastoras (CAZES, 2012).

Enquanto o cavaquinho dos blocos acabou sendo o cavaquinho das Escolas de Samba, o cavaquinho nos Regionais de Choro passou a acompanhar toda sorte de estilos musicais nos programas de rádio. Com o aparecimento do novo samba, o samba batucada, o samba do Estácio, o samba moderno, os Regionais procuraram descobrir um jeito de dar uma roupagem satisfatória ao novo gênero. Os cantores de samba da época, como Carmen Miranda, Francisco Alves e Orlando Silva, davam preferência ao acompanhamento do Regional de Benedito Lacerda, que tinha Canhoto como cavaquinista e o balanço perfeito para acompanhar o novo samba. Foi a partir daí que o cavaquinho se fixou definitivamente como instrumento essencial no acompanhamento do samba. Até hoje o principal mercado de trabalho para os cavaquinistas é o samba (CAZES, 2012).

Cada cavaquinista,quando acompanha um samba, coloca o seu "tempero" próprio, de modo que a palhetada pode se diferenciar de um cavaquinista para outro. Esse fato faz gerar uma diversidade de levadas rítmicas muito positiva, que enriquece o modo de tocar o instrumento. Destaco aqui "Seu"Jair do Cavaquinho, que compôs o samba "Barracão de Zinco”, Mané do Cavaco, que tocou com Martinho da Vila nos anos 1960, e Paulinho da

\footnotetext{
${ }^{54}$ Geral: parte de um estádio de futebol, hoje extinta, onde os expectadores assistiam aos jogos em pé, no nível do gramado. As brigas que ali aconteciam entre os torcedores, ficaram famosas.
} 
Viola, que ajudou a popularizar o cavaquinho na década de 1970. "O bom cavaquinista tem o ouvido apurado e um swing de mão direita que transforma o instrumento, por meio das palhetadas, em elementos de percussão também" (MACHADO \& MARTINS, 2006, p. 96).

Exposto às influências externas de outras modalidades musicais brasileiras, o samba começou a sofrer alterações e modificações que culminaram em derivações do gênero como, entre outras: o samba-canção, que traz um ritmo mais contido e enfatiza a melodia, geralmente romântica e sentimental; o samba-choro, uma adaptação do choro cantado, que aproveita as frases musicais do choro emitidas pela flauta e a percussão do batuque; o samba de breque, que é uma variação do samba-choro com fermatas (paradas) onde o cantor faz pequenos comentários relacionados ao tema da música, geralmente humorísticos; o samba-enredo, criado para os desfiles das escolas de samba, contém em sua letra o tema proposto por cada escola, que pode ser folclórico, histórico, biográfico ou mesmo um tema livre (MELLO, 1998, p. 705). O cavaquinho está presente em todas essas modalidades de samba.

Mais recentemente, uma nova versão do samba ganhou força e dominou o mercado fonográfico, o pagode. Com o pagode, entrou em voga o banjo-cavaco, que é um banjo com a mesma escala e afinação de um cavaquinho e, aproximadamente, o mesmo comprimento, no entanto com a caixa de ressonância arredondada e, em seu tampo, uma pele de couro ou acrílico esticada por uma armação de metal que lhe confere um volume de som muito alto. É importante frisar que o cavaquinho também é usado no pagode, ao lado do banjo-cavaco. $\mathrm{Na}$ figura a seguir temos uma foto de um banjo-cavaco e de um cavaquinho, onde se pode constatar que os dois instrumentos possuem tamanhos semelhantes.

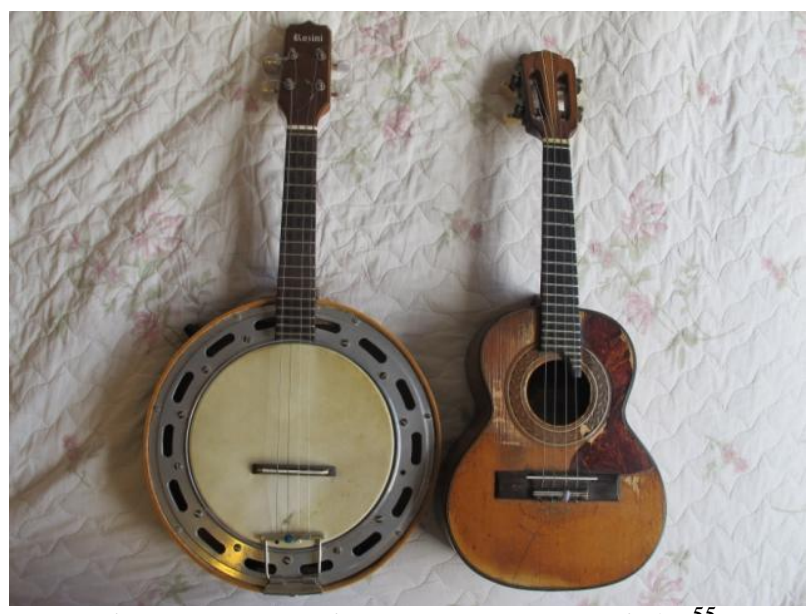

Figura 28 - Banjo-cavaco e cavaquinho ${ }^{55}$

\footnotetext{
${ }^{55}$ Foto tirada por mim, em 10/04/2015, de instrumentos de minha coleção pessoal.
} 
Vimos nessa parte do trabalho que o samba nasceu na Bahia e migrou para o Rio de Janeiro onde ganhou uma nova cara, nascendo assim o samba carioca, esse que conhecemos hoje e ficou famoso no mundo todo. Vimos também que o cavaquinho esteve presente nas transformações socio-culturais que levaram ao nascimento do samba. E ainda que o cavaquinho está vivo. Presente no samba atual, com sua força rítmica-harmônica e sua alegria dançante.

\section{4 - O cavaquinho em outros gêneros musicais e no folclore}

Além da presença indispensável no samba e no choro, o cavaquinho também é encontrado no baião, no frevo, no maxixe, na marcha de carnaval e em manifestações folclóricas musicais como Bumba-meu-boi, Folia de Reis, Pastoris, Ranchos, Moçambique, Fandango, Jongo, Carimbó, Cacuriá e Congada. Grande parte desses folguedos ocorre nas ruas e o cavaquinho neles aparece basicamente como instrumento de acompanhamento, fazendo poucas intervenções de solo, trazendo traços de sua origem portuguesa, nos remetendo a uma comparação com as manifestações culturais da região do Minho onde o cavaquinho teria surgido e adquirido popularidade.

Nesse ponto da dissertação, gostaríamos de dedicar algumas linhas no sentido de fornecer uma breve ideia da participação do cavaquinho nas expressões culturais que citamos acima, sejam elas pertencentes à música popular ou à música folclórica que, apesar de caminharem lado a lado e se influenciarem mutuamente, se diferenciam em alguns aspectos.

No livro Vivência e Projeção do Folclore, de Renato Almeida, encontramos as seguintes definições:

Música Folclórica é aquela que, criada ou aceita coletivamente no meio do povo, se mantém por transmissão oral, transformando-se, variando ou apresentando aspectos novos, e destinada à vida funcional da coletividade.

Música Popular é aquela que é criada por autor conhecido, dentro da técnica mais ou menos aperfeiçoada e se transmite pelos meios comuns de divulgação musical (ALMEIDA, 1971, p. 90).

Portanto, a música folclórica traz composições coletivas, anônimas, do passado remoto ou do presente. É divulgada oralmente nos festejos, folguedos e autos. É, também, uma tradição que atravessa gerações e está ligada às manifestações religiosas e profanas. A música 
popular é criada por um autor conhecido, seguindo uma técnica estudada e é divulgada por meios como rádio, televisão, partituras, entre outros.

\subsection{1 - Maxixe}

Surgiu na segunda metade do século XIX na Cidade Nova, região do Canal do Mangue, no Rio de Janeiro.

Considerada a primeira dança urbana surgida no Brasil. Foi por algum tempo expoente da nossa dança urbana, tendo cedido lugar ao samba. Resultou da fusão da habanera pela rítmica, e da polca pela andadura, com adaptação da síncopa africana (CASCUDO, 2012, p. 443).

José Ramos Tinhorão emite sua versão a respeito do surgimento do maxixe:

O aparecimento do maxixe, inicialmente como dança, por volta de 1870 , marca o advento da primeira grande contribuição das camadas populares do Rio de Janeiro à música do Brasil. Nascido da maneira livre de dançar os gêneros de música em voga na época, principalmente a polca, a schottisch e a mazurca, o maxixe resultou do esforço dos músicos de choro em adaptar o ritmo das músicas à tendência aos volteios e requebros de corpo, com que mestiços, negros e brancos do povo teimavam em complicar os passos das danças de salão (TINHORÃO, 2013, p. 71).

Considerada dança indecente, por seu caráter lúdico e sensual, o maxixe foi marginalizado por boa parte da sociedade. A dança ganhou força ao ser tocada em clubes carnavalescos e no Teatro de Revista, sendo divulgada por grupos de choro, bandas de músicas e "pianeiros" (DINIZ, 2006, p. 24). "Ao que parece, a primeira apresentação do maxixe no teatro carioca ocorreu em 1883 no espetáculo "Aí Caradura”, cuja maior atração era os trechos de maxixe cantados e dançados" (ALBIN, 2006, p. 463).

A pesquisadora e cavaquinista, Ana Claudia Cesar completa:

O Maxixe, como já foi dito, nasce como dança popular urbana e, aos poucos, se transforma em música instrumental e também em canção, muito difundida pelo Teatro de Revista. Muitos elementos musicais do maxixe estão presentes no choro; a diferença está na sua função social: maxixe era música para se dançar, e o choro não trazia esta mesma intenção (CESAR, 2013, p. $30)$.

Como gênero musical, o maxixe se parece com o samba e, como vimos, acabou por influenciar compositores da primeira fase do samba feito no Rio de Janeiro - o samba amaxixado -, entre eles, Donga e Sinhô. O cavaquinho estava por lá, como instrumento 
rítmico-harmônico, acompanhando as mudanças sonoras e culturais entre o maxixe e o samba. Outro gênero musical que teria absorvido as influências do maxixe é o frevo, como veremos mais à frente.

\subsection{2 - Baião}

Este gênero musical nasceu no Nordeste e seu nome deriva de uma dança denominada baiano, ${ }^{56}$ que, segundo José Ramos Tinhorão, "é uma forma especial dos violeiros tocarem lundus na zona rural do nordeste" (TINHORÃO, 2013, p. 51).

O baião se popularizou através do compositor Luiz Gonzaga do Nascimento (19121989), o Gonzagão, e suas composições em parceria com Humberto Cavalcanti Teixeira (1915-1979), entre elas Asa Branca. O grupo ou trio de baião, como hoje o conhecemos, é formado basicamente por sanfona, triângulo e zabumba, formação introduzida por Luiz Gonzaga. A rabeca, a viola caipira e o pife (tipo de flauta com timbre agudo) também são instrumentos bastante utilizados nesse gênero musical, porém não tão populares como o trio de baião.

Gonzaga e Humberto Teixeira chegaram à conclusão de que, entre os ritmos do Nordeste, um deles, desconhecido no Rio, seria o mais estilizável e urbanizável de todos; o baião. [...] Começaram então a trabalhar para lançálo nacionalmente, produzindo um baião em estilo próprio, substituindo os instrumentos originais - viola, pandeiro, botijão e rabeca - por acordeom, triângulo e zabumba (ALBIN, 2003, p. 146).

O compositor e solista de cavaquinho Waldir Azevedo (1923-1980), aproveitando o sucesso de Luiz Gonzaga, lançou na mesma época, meados do século XX, o baião Delicado. O sucesso desse baião solado no cavaquinho veio coroar a fusão entre o gênero e o instrumento e ainda "abriu caminho para a divulgação do novo ritmo em todo o mundo" (TINHORÃO, 2013, p. 257). Alguns anos depois Waldir gravou outro baião de sua autoria: Arrasta Pé.

José Siqueira de Alcântara (1937), mais conhecido como Siqueira do Cavaco, também compôs um baião no cavaquinho, Influência da Região, onde se percebe o entrelaçamento do baião com o frevo de Pernambuco, sua terra natal. Ormindo Fontes de Melo (1933), o Toco

\footnotetext{
${ }^{56} \mathrm{O}$ baiano é um produto do mestiço; é a transformação do maracatu africano, das danças selvagens, e do fado português (CASCUDO, 2012, p. 88).
} 
Preto, atuou com seu cavaquinho acompanhando grupos de música nordestina. Sobre esses músicos falaremos um pouco mais no terceiro capítulo.

\subsection{3 - Pastoril}

Inicialmente, eram cantos de louvor diante do presépio de Natal. Os grupos de cantores vestiam-se de pastores e representavam a visitação ao estábulo do nascimento de Cristo, levando presentes e pedidos de bênção."Essas representações foram introduzidas no Brasil pelos padres e as mais velhas referências que sobre elas se tem, datam dos últimos vinte anos do século XVI" (ALVARENGA, 1950, p. 76).

O pesquisador João Ferreira Gomes, mais conhecido como Jota Efegê, completa:

À frente desses bandos festivos, graciosa menina vestida com alva túnica branca trazia na ponta de uma vara, o mais alto possível, uma pequenina estrêla. Era a guia, a estrela que levara os magos do Oriente à estrebaria humilde onde se encontrava o Messias (EFEGÊ, 2007, p. 17).

Os Pastoris ou pastorinhas evoluíram para autos, mais profanos que religiosos, como escreveu Oneyda Alvarenga:

Do seu tipo inicial constituído talvez apenas de cânticos em louvor do nascimento de Jesus, os Pastoris passaram no século XIX, época de seu grande florescimento, a ser representações completamente profanizadas, mantendo muito fracas ligações com o acontecimento religioso festejado. A mistura de elementos burlescos e maliciosos desagradou a tal ponto a Igreja, que em 1801 as autoridades eclesiásticas de Pernambuco solicitavam ao governo a repressão da "função das chamadas Pastorinhas"(ALVARENGA, 1950, p. 76).

Segundo consta no Dicionário do Folclore Brasileiro de Câmara Cascudo, os Pastoris são representados em palcos e tablados e a presença, antes obrigatória, do presépio ou de imagens está dispensada. Cascudo observa que o canto das pastoras é acompanhado por pandeiros e orquestra de "pau e corda": violões, cavaquinhos e um instrumento de sopro solista (CASCUDO, 2012, p. 536-537). O pesquisador Artur Ramos se refere a conjuntos antigos de pistão, trombone, clarineta, bombardino e bombo e o folclorista Renato Almeida, fala em violão, bandolim, cavaquinho, clarineta e pandeiro (ALVARENGA, 1950, p. 77). O papel do cavaquinho no Pastoril é de instrumento acompanhador, eventualmente pode ser feito algum solo. 


\subsection{4 - Rancho}

Grupo de festeiros das solenidades natalinas que valoriza as vestimentas coloridas. Seus instrumentos são o violão, o cavaquinho, a viola, o ganzá, o prato e às vezes a flauta, que acompanham os cantos das pastoras e pastores. A procissão passa cantando, tocando e pedindo agasalhos pelas casas. Também chamada de reisado no centro do estado da Bahia, é uma manifestação folclórica vinda do norte de Portugal, das regiões do Douro e do Minho (CASCUDO, 2012, p. 604-605). Segundo o pesquisador Jota Efegê, os Ranchos são derivados dos Pastoris e "mais do que aqueles, profanaram seus mitos. A religiosidade da origem tomou feição recreativa através de uma concepção alegórica” (EFEGÊ, 2009, p. 19). Para Mário de Andrade, os Ranchos são "mais ou menos o mesmo que os ternos, isto é, agrupamento de pessoas que cantam e dançam” (ANDRADE, 1989, p. 426).

Os ranchos trazem um figurante principal que dá nome ao rancho, podendo ser uma planta, um objeto, um personagem de fábula ou preferencialmente um animal que é conduzido à lapinha. Além de pastoras, existem elementos ornamentais como balizas, porta-machados, porta-bandeiras, mestres-salas e ainda um ou dois personagens que lutam com a figura principal. A dança é o lundu sapateado (MELLO, 1998, p. 663).

Nos antigos ranchos os foliões cantavam seus versos e foi aí que se deu o surgimento do gênero musical marcha. Chiquinha Gonzaga compôs a marchinha Ó Abre Alas, para o cordão carnavalesco Rosas de Ouro, cantada até hoje nos bailes carnavalescos. "Os ranchos foram o embrião das Escolas de Samba" (CAZES, 2012).

José Ramos Tinhorão nos ajuda a entender esse momento da nossa música brasileira de carnaval:

Até os primeiros anos do século $\mathrm{XX}$, as músicas cantadas no carnaval tanto podiam ser os velhos estribilhos de sabor africano divulgados pelos antigos Ranchos de baianos da Saúde, ou pelos cucumbis de afoxés de escravos, como as polcas, modas sertanejas e até as valsas dos brancos, lançadas durante $\mathrm{o}$ ano em partituras para piano.

Isso se dava porque o carnaval, mal saído do entrudo - que não levava em conta a música, mas a brincadeira grossa de molhar os passantes com seringas d'água - ainda não possuía qualquer organização.

Foram os ranchos que, ao adotarem a formação das procissões religiosas, instituíram um mínimo de disciplina em meio ao caos do carnaval sugerindo desde logo à maestrina Chiquinha Gonzaga, em 1899, motivo para a marcha "Ó Abre Alas", declaradamente inspirada na cadência que os negros 
imprimiam à passeata, enquanto desfilavam cantando suas músicas "bárbaras" (TINHORÃO, 2013, p. 139).

Assim como nos Pastoris, o cavaquinho no rancho é instrumento basicamente acompanhador, o que não impede que ocorra, esporadicamente, algum solo.

\subsection{5 - Marcha}

A marcha é um ritmo carnavalesco que tem sua origem nos grupos denominados ranchos, surgidos na segunda metade do século XIX e que tinham entre seus instrumentos o cavaquinho.

Sobre a marcha, Câmara Cascudo nos esclarece:

A marcha carnavalesca que se tornou música de dança, espevitada, maliciosa e brejeira, é excepcionalmente a nossa música alegre. Também semi-erudita também carioca iniciou-se com os cordões e Ranchos carnavalescos.

Durante o carnaval no Brasil, no Rio de Janeiro preferencialmente, os Ranchos aparecem como grupos de foliões, com instrumentos de corda e sopro, cantando em coro versos musicados e alusivos ao grupo, a marcha do rancho ou mesmo os mais populares na ocasião (CASCUDO, 2012, p. 433; $605)$.

Vimos que o cavaquinho, mais uma vez, auxiliou com sua sonoridade as mudanças e transformações que ocorreram na nossa música. Dessa vez, presente entre os instrumentos que faziam parte das orquestras dos ranchos. A função básica do cavaquinho na marcha é de instrumento acompanhante, podendo fazer pequenas intervenções melódicas.

\subsection{6 - Frevo}

A palavra frevo se originou de uma maneira regional em pronunciar a palavra ferver, o que faz sentido visto que o frevo é um gênero musical de ritmo sincopado, quente, vigoroso e frenético. Segundo José Ramos Tinhorão, o frevo surgiu na década de 1880 e é uma criação de músicos brancos e mulatos, participantes de bandas marciais que tocavam polcas, tangos, quadrilhas e maxixes (TINHORÃO, 2013, p. 161). O Frevo se assemelha à marcha, porém com o andamento bem mais rápido. 
Luis da Câmara Cascudo emite suas idéias a respeito do "parentesco" entre o frevo e a marchinha, em seu livro Dicionário do Folclore Brasileiro:

É uma marcha com divisão em binário e andamento semelhante ao da marchinha carioca, mais pesada e barulhenta e com uma execução vigorosa e estridente de fanfarra. Nele o ritmo é tudo, afinal a sua própria essência, ao passo que na marchinha a predominância é melódica (CASCUDO, 2012, p. $315)$.

No encarte do LP Capiba e Nelson Ferreira, da coleção Nova História da Música Brasileira, Guerra-Peixe exprime suas concepções sobre o frevo:

Como gênero musical, o frevo não é folclore, ao contrário do que muitos pensam, mas constitui e constituirá ainda por muito tempo um gênero de música popular especial, porque contém um forte apelo popular (GUERRAPEIXE, 1978, p. 12).

Tocado com muita percussão e instrumentos como trombone, pistão, clarinete e saxofone, o frevo tornou-se o ritmo oficial do carnaval pernambucano e arrasta multidões ao passar pelas ruas do Recife e de Olinda. Sua execução é difícil e requer técnica apurada dos instrumentistas. Suas prováveis influências estão nos gêneros musicais habanera, maxixe e nas bandas militares, afirma o folclorista Edison Carneiro:

O frevo - diz Edison Carneiro - deriva de formas musicais do começo do século, tais como a habanera e o maxixe, músicas semi-eruditas, ou que pelo menos fogem à técnica do povo. A própria textura do frevo-música não é popular por ser complexa e o fato de ser necessária a presença de banda, com instrumentos caros (trombone, tuba, saxofone), anula o caráter de manifestação folclórica: o povo não tem dinheiro para comprar instrumentos caros (CARNEIRO apud GUERRA-PEIXE, 1978, p. 12).

O frevo também é cantado, frevo-canção, e tocado por blocos que exibem instrumentações diversas. Alguns deles sem nenhum instrumento de metal, possivelmente com origens ligadas aos pastoris e a grupos de serenatas que em carnavais passados invadiam as ruas com instrumentos de "pau e corda", entre os quais o cavaquinho. Esses blocos são conhecidos como os blocos líricos.

A respeito de blocos carnavalescos, Câmara Cascudo escreveu:

No vocabulário do carnaval é um grupo com indumentária uniforme tendo um hino-marcha, composto para o folguedo, e que se exibe nos três dias da folia cantando qualquer cantiga popular. [...] Outrora só blocos tomavam encargos de críticas e sátiras políticas e sociais. [...] Os blocos são sempre acompanhados de um pequeno conjunto musical, sax, violões, (cavaquinhos), banjos, pandeiros (CASCUDO, 2012, p. 114). 
O livro Frevo Cem Anos de Folia traz referências sobre os blocos líricos, o "frevo de bloco", inicialmente denominado "marcha de bloco":

Suas orquestras conhecidas como de pau e corda, traziam originalmente apenas violões (sendo que as maiores chegavam a ter mais de quarenta), cavaquinhos, violinos, banjos, bandolins, e contrabaixo, além de um extenso coral formado por mulheres. Com o passar dos anos, novos instrumentos de percussão, palhetas e metais, foram sendo incorporados às orquestras, além das vozes masculinas no coro (CASSOLI \& FALCÃO, 2007, p. 59).

Passando pelo aeroporto de Recife observei uma série de apresentações de bandas de frevo, orquestras de metais, com a percussão a cargo de um surdo e uma caixa clara. É contagiante o ritmo, a sonoridade, os improvisos, os arranjos. Tudo muito bem executado, impossível ficar parado, pelo menos os pés batendo no chão ou a mão batucando na mesa é o que se vê na reação do público ao ouvir aquela música contagiante e fervente.

Entre as orquestras que se apresentaram estava a Orquestra Vienna, de Recife. Um de seus músicos, o trombonista Raffael Santana da Silva, na ocasião me concedeu uma entrevista da qual transcrevi, na íntegra, o seguinte depoimento a respeito do cavaquinho no frevo, nos blocos líricos:

O carnaval do Recife que usa instrumentos de corda, como o cavaquinho, banjo, violão sete cordas, violão seis cordas, é mais tradicional em cima dos blocos líricos, que são os antigos blocos de carnavais, que ainda continuam com aquele mesmo segmento, o carnaval de rua, o carnaval cantado, com poucos metais, mais cordas, com um coro, de homens e mulheres, que vai a frente, cantando os frevos. Na frente dos metais, vai a parte das orquestras, no caso a orquestra de cordas que "faz a mistura", como se diz aqui, algumas tem até violino e ajudam na melodia e na harmonia e dão descanso para as vozes (SILVA, 2015).

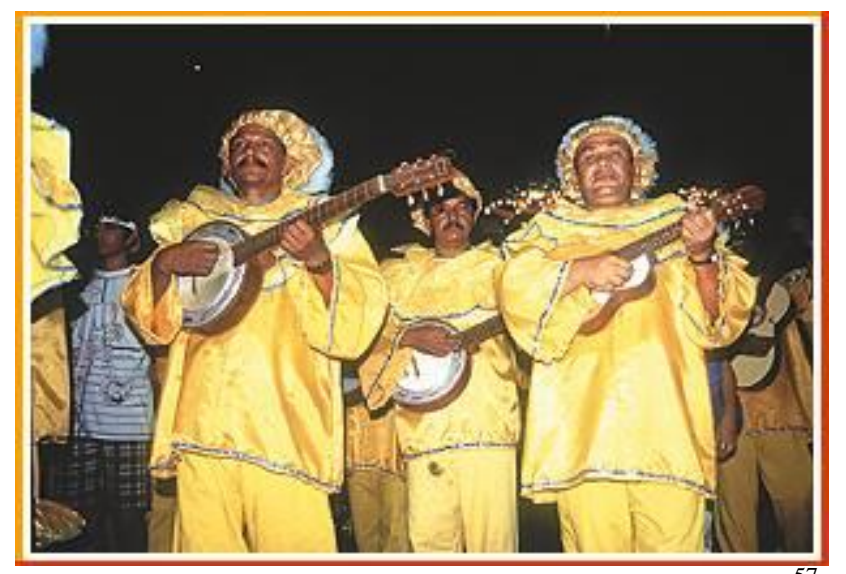

Figura 29 - Bloco Lírico com Orquestra de Cordas

${ }^{57}$ Disponível em: http://www.recife.pe.gov.br/especiais/brincantes/2c.html. Acesso em: 05/01/ 2015. 
$\mathrm{Na}$ figura anterior, o cavaquinho aparece em uma das Orquestras de Cordas, que acompanham os Blocos Líricos, juntamente com dois banjos e um violão.

O frevo migrou para a Bahia, onde foi acolhido com outra roupagem instrumental. Ali o frevo foi eletrificado por Dodô e Osmar, criadores do Trio Elétrico: caminhões equipados com potente aparelhagem de som que saem pelas ruas de Salvador e de outras cidades baianas, animando os carnavais. No Trio Elétrico o frevo é tocado com muita percussão, bateria, baixo elétrico, um ou dois instrumentos harmônicos (guitarra, teclado) e a guitarra baiana ${ }^{58}$, que é um cavaquinho na forma de guitarra elétrica, responsável pelos solos melódicos e improvisos.

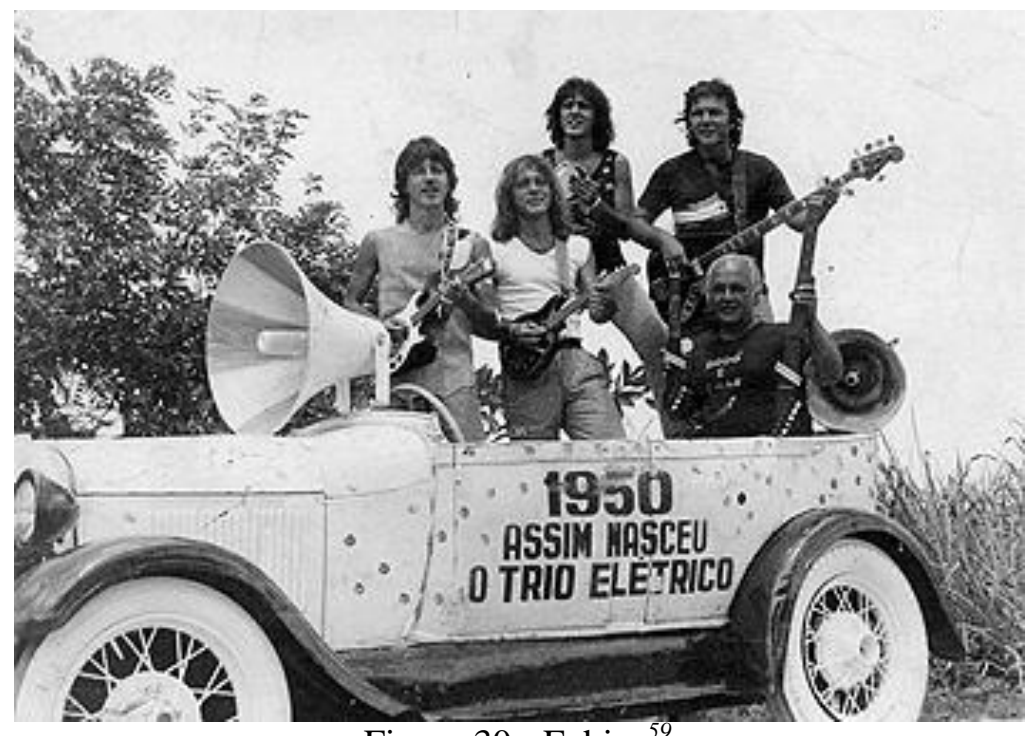

Figura 30 - Fobica ${ }^{59}$

Na imagem anterior vemos o que foi o embrião do Trio Elétrico, a "Fobica", um Ford 1929. Empunhando as guitarras baianas, da esquerda para a direita os irmãos Aroldinho e Armandinho, sentado o pai Osmar Macedo, com o "pau elétrico" ${ }^{60}$. Os outros não foram identificados.

Waldir Azevedo, solista de cavaquinho, gravou frevos famosos. No disco Waldir Azevedo (1977), registrou Vassourinhas, de Mathias da Rocha e Joana Batista Ramos (clássico do gênero, que é tocado em todos os carnavais, provavelmente o frevo mais conhecido) e São Paulo Quatrocentão, de autoria de Garoto e Chiquinho. No disco Minhas

\footnotetext{
${ }^{58}$ Como já vimos, na guitarra baiana se usa as afinações de bandolim e de cavaquinho.

59 Disponível em: http://bragganeto.blogspot.com.br/2012/02/antigamente-era-assim-o-primeiro-trio.html. Acesso em: 07/02/2015.

${ }^{60}$ Pau Elétrico: instrumento inventado por Osmar Macedo que é somente o braço do cavaquinho eletrificado, com som amplificado. Depois, acoplado o corpo de madeira maciça, se transformou na guitarra baiana.
} 
Mãos Meu Cavaquinho (1976), gravou o Frevo da Lira, uma composição sua em parceria com Luiz Lira. Ambos os discos foram lançados pela gravadora Continental.

\subsection{7 - Fandango}

Segundo Luís da Câmara Cascudo, a palavra Fandango tem vários sentidos no Brasil. No Norte e Nordeste também é conhecido como Marujada, Chegança de Marujos ou Barca, e se trata de uma dança dramática, mais especificamente um auto, que acontece na época do Natal, com personagens vestidos de marinheiro que cantam e dançam ao som de uma orquestra formada por rabecas, violões, violas, cavaquinhos e banjos. A música possui influência europeia por suas soluções melódicas e quadratura das estrofes cantadas. O tema é relacionado com as grandes navegações portuguesas. Os marujos puxam pelas ruas um pequeno navio, com as velas abertas, até um tablado geralmente armado em frente à matriz, onde acontece a representação, sempre ao ar livre (CASCUDO, 2012, p. 291-292).

No litoral paranaense e paulista existe a variante Fandango Caiçara ${ }^{61}$, associada à organização de trabalhos coletivos como mutirões, puxadas de rede, colheitas e construções, onde o organizador oferece uma festa, como pagamento aos ajudantes voluntários. No Fandango Caiçara o cavaquinho aparece como instrumento harmônico e certamente no Fandango do Nordeste, cumpre o mesmo papel.

No Sul, a partir de São Paulo até o Rio Grande do Sul, Fandango é baile, festas, função, em que se dançam várias danças regionais com influências gauchescas vindas das repúblicas do Rio da Prata (CASCUDO, 2012, p. 291). Nos bailes sulistas não foi identificada a presença do cavaquinho.

\footnotetext{
${ }^{61}$ Disponível em: http://www.aposolhe.blogspot.com.br/2007/08/Fandango-caiara.html. Acesso em: 09/06/2015.
} 


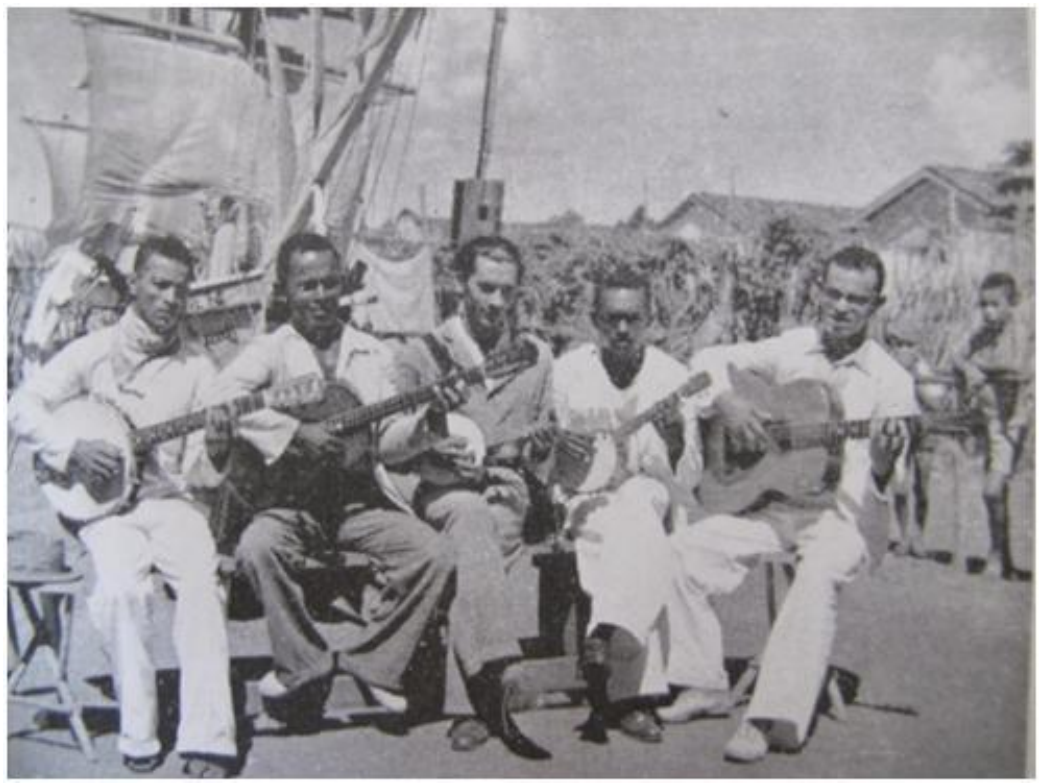

Figura 31 - Instrumentos de corda na Barca ${ }^{62}$

A foto anterior, tirada no dia 24/05/1938, mostra um grupo de instrumentistas do Fandango, Marujada ou Barca em João Pessoa (PB), no bairro de Torrelândia. Da esquerda para direita observa-se a presença de um banjo, um violão, dois banjos-cavacos e outro violão.

Oneyda Alvarenga, em seu livro Música Popular Brasileira, aponta para outra formação de músicos na Chegança de Marujos: "Melo Moraes Filho se refere para a chegança de marujos a guitarras, violões, cavaquinhos, pistão, rabeca, flauta ou clarineta" (ALVARENGA, 1950, p. 75).

\subsection{8 - Folia de Reis}

De origem europeia, acontece a partir da véspera de Natal, dia 24 de dezembro, até o dia 02 de fevereiro, dia de Nossa Senhora das Candelárias. Os participantes, que representam os próprios Reis Magos, com bandeiras, fitas coloridas e palhaços, sob o comando do Alferes, pedem qualquer ajuda. Saem cantando de manhã cedo, acompanhados por banda de música, pelas ruas e vão, de casa em casa, onde são recebidos com café da manhã ou uma pequena refeição. Os instrumentos são violões, cavaquinho, pandeiro, pistão e tantã (um tipo de tambor). No dia 06 de janeiro, dia de Reis, realizam uma festa e com o montante angariado, uma ceia em 02 de fevereiro (CASCUDO, 2012, p. 306).

${ }^{62}$ Foto extraída do livro Música Popular Brasileira de Oneyda Alvarenga. 


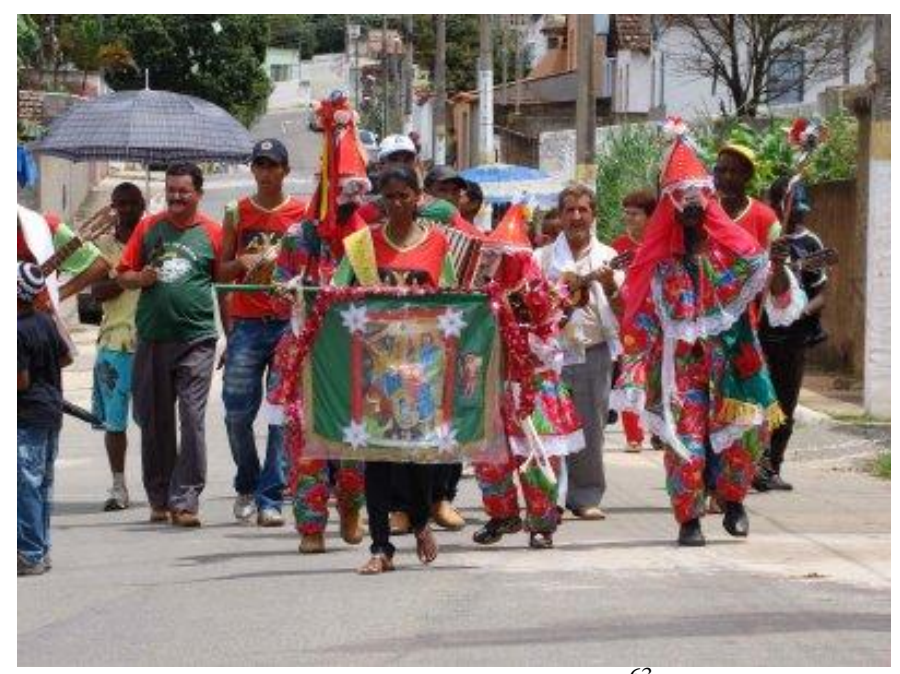

Figura 32 - Folia de Reis ${ }^{63}$

Na figura anterior podemos observar um cortejo de Folia de Reis com seus palhaços, suas bandeiras e entre os músicos um tocador de cavaquinho que harmoniza os cantos ao lado de dois violeiros.

\subsection{9 - Bumba-meu-boi}

A dança dramática Bumba-meu-boi é provavelmente a festa popular mais conhecida do folclore brasileiro. Mais comum no Maranhão, conta a vida, morte e ressurreição de um boi, representado por uma armação recoberta por um pano colorido e animado por um homem em seu bojo. Na região amazônica, a festa é conhecida por Boi-Bumbá e no litoral de Santa Catarina por Boi de Mamão.

A instrumentação usada no Boi do Maranhão é bastante percussiva, com instrumentos próprios como o maracá, espécie de chocalho, a matraca, que é formada por duas tábuas que produzem sons agudos quando batidas uma contra a outra, o pandeirão, e o tambor-onça, uma espécie de cuíca gigante.

Por ocasião do $37^{\circ}$ Curso de Verão da Escola de Música de Brasília entrevistei o percussionista maranhense Carlos Henrique Lobato Nogueira, conhecido como Carlos Pial,

\footnotetext{
${ }^{63}$ Disponível em: <http://3.bp.blogspot.com/8DJ1CENDqrE/T2dooawCGwI/AAAAAAAACXs/zPox5m6zqpc/s1600/folia+de+reis1.jpg>. Acesso em: 05/01/2015.
} 
que fundou na capital federal um Instituto de Percussão com seu nome. Ao ser indagado sobre o cavaquinho no Boi do Maranhão, Pial declarou:

O mais comum é o banjo, só que na época do Junino, como são muitos grupos de Boi de Orquestra, que usam os banjos... acabam os banjistas e aí eles saem pegando os cavaquinhos e fica perfeito, fica lindo com $o$ cavaquinho (NOGUEIRA, 2015).

A folclorista Oneyda Alvarenga ratifica a presença do cavaquinho no Bumba-meu-boi:

No Bumba-meu-boi apenas as figuras humanas cantam. Do acompanhamento instrumental encarregam-se pequenos conjuntos em que aparecem violão, viola, cavaquinho, tambor, pandeiro, ganzá, maracá, sanfona, gaita, flautim, clarinete e rabeca (ALVARENGA, 1950, p. 44).

Nota-se que o aparato instrumental do Boi varia de região para região e pode ser bastante diversificado. No Dicionário do Folclore Brasileiro encontramos a seguinte definição para Boi-Bumbá com uma proposta de instrumentação que usa o cavaquinho:

Festa popular que se realiza em Belém do Pará e nos seus arredores, pelo São João. Consiste na exibição de um boi de pau e pano, conduzido por dois personagens - Pai Francisco e Mãe Catirina - que são acompanhados por dois ou três cavalos e uma orquestra composta de rabecas e cavaquinhos. É uma variante transparente do Bumba-meu-boi do Nordeste (CASCUDO, 2012, p.117).
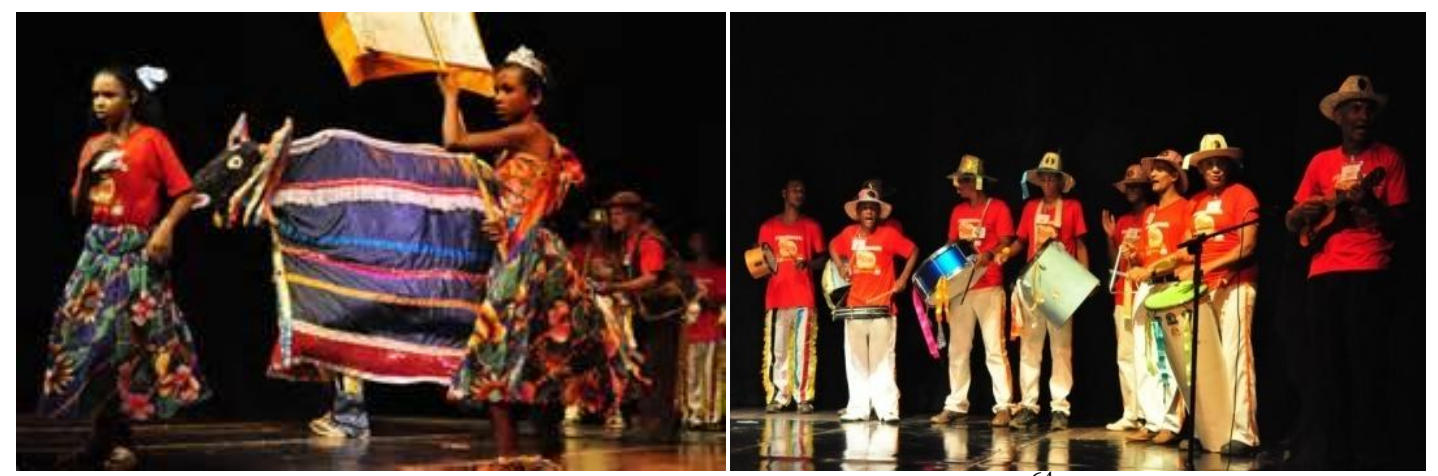

Figuras 33 e 34 - Bumba-meu-boi de Una

Nas figuras 33 e 34 podemos apreciar uma formação do Boi no palco - na cidade baiana de Una -, na qual o cavaquinho está presente, como único instrumento de harmonia. Como podemos constatar, foi preciso o uso de um microfone no cavaquinho para nivelar o volume de som com todos os instrumentos de percussão.

${ }^{64}$ Disponível em: http://euvejoarte.blogspot.com.br/2011/07/Bumba-meu-boi-de-una-trofeu-destaque-no.html Acesso em: 05 /01/ 2015. 


\subsubsection{0 - Moçambique}

A origem do nome vem de dança africana do tempo da escravidão. Era praticada nos sertões pelos primeiros escravos mineiros que trabalhavam na extração de ouro. Hoje o "Moçambique" é africano só no nome, perdeu grande parte de seus elementos tipicamente negros, como o canto em uníssono, a formação em roda, a figura de um ou dois solistas no centro. Com motivos populares e religiosos, faz devoção à Nossa Senhora do Rosário, a São Benedito e aos festejos do Divino. Ocorre nos estados de Goiás, Minas Gerais, São Paulo e Rio Grande do Sul (CASCUDO, 2012, p. 454-55).

Os foliões simulam uma batalha de bastões, que representam espadas, com coreografia movimentada dispostos em filas ou arabescos. Suas vestimentas são túnicas azuis ou vermelhas com guizos presos aos tornozelos e capacetes enfeitados de fitas e espelhos. Os instrumentos usados são de percussão, mas podem aparecer conjuntos com viola, violão, rabeca e cavaquinho (ibidem).

\subsubsection{1 - Congada}

A Congada é um desfile ou procissão que reúne elementos das tradições tribais do Congo e de Angola, com influências ibéricas no que se refere à religiosidade. Animada por danças, lutas de espadas (bastões), cantos e música, a procissão segue até uma igreja (em geral, de irmandades de negros, como Nossa Senhora do Rosário) onde, com a presença de uma corte e seus vassalos, ocorre a cerimônia de coroação do Rei Congo e da Rainha Ginga de Angola, defensora da autonomia de seu reinado contra os portugueses. No Brasil a Congada acontece no Norte, Centro e Sul do país. No Rio Grande do Norte o rei é Henrique, Rei Cariongo. Apesar do nome, essa manifestação folclórica não existia no território africano (CASCUDO, 2012, p. 218).

Oneyda Alvarenga nos define as Congadas como:

Danças dramáticas que misturam no seu entrecho tradições e costumes africanos e elementos tomados a outros bailados de origem luso-espanhola. Constituem, essencialmente um cortejo real, a que se liga uma parte representada, Embaixada, versando assunto guerreiro (ALVARENGA, 1950, p. 90). 
A música é executada por viola, cavaquinho, tambores, caixa, pandeiro e vários tipos de chocalhos. A Enciclopédia da Música Brasileira, sob coordenação de Oneyda Alvarenga, confirma a presença do cavaquinho no Moçambique e nas Congadas paulistas (ALVARENGA, 1998, p. 185; 210).

\subsubsection{2 - Jongo}

É uma dança africana que ocorre nos estados de São Paulo, Minas Gerais, Espírito Santo e Rio de Janeiro, de forte parentesco com o samba. Seus participantes se vestem de branco e as mulheres usam saias rodadas, que lembram as baianas.

Os dançarinos se dispõem em uma roda que gira no sentido lunar, sentido anti-horário, comum em danças africanas. Dois deles, geralmente um homem e uma mulher, vão para o centro da roda, onde travam uma espécie de batalha, exibindo os mais variados passos. A dança é lenta, semelhante à que vemos no candomblé, com passinhos pra frente e pra trás, que são acompanhados pelos movimentos de braços no mesmo sentido. Por vezes os dançarinos giram em torno de si mesmos (CASCUDO, 2012, p. 379).

O Jongo é cantado por um ou mais solistas, com resposta cantada pelo coro, acompanhado pelos tambores tambú, candongueiro e gazungá, ao lado da cuíca e da angoia (cestinha de vime com caroços), que produz um som semelhante aos chocalhos.

Apesar da instrumentação do Jongo ser basicamente composta por vários tambores, atabaques de diversos tamanhos, pode ocorrer a presença de um cavaquinho como afirma Ricardo Cravo Albin: "Recentemente têm-se visto violões e cavaquinhos no acompanhamento e alguns conjuntos usam até instrumentos de sopro em apresentações de caráter comercial" (ALBIN, 2006, p. 375).

No ano de 1988 tive a oportunidade de participar, com meu cavaquinho, do Jongo da Serrinha, em Madureira (RJ), sob o comando do Mestre Darcy. A palhetada me foi ensinada por Jacaré do Cavaco, que já tocava por lá. Foi uma experiência fascinante, que sempre carrego na lembrança. 


\subsubsection{3 - Carimbó}

É uma dança que apresenta traços da cultura ameríndia, africana e portuguesa, nascida no estado do Pará, onde é tradição local. Formado um círculo de homens e mulheres, uma dançarina vai ao centro, geralmente vestida de baiana, e dança com seus requebres e trejeitos. Gira em torno de si mesma, jogando a barra da saia sobre o parceiro mais próximo, cobrindo-o e causando hilaridade. Se a saia não cobrir o visado, a dançarina é substituída na posição que ocupava na roda. Os instrumentos usados são o carimbó (tambor escavado em tronco), pandeiro, reco-reco e, ocasionalmente, instrumentos de cordas (CASCUDO, 2012, p. 76). O Carimbó que, segundo Ricardo Cravo Albin, tem sonoridade semelhante ao batuque, foi divulgado pela cantora Fafá de Belém na década de 1970 (ALBIN, 2006, p. 154). Em viagem à cidade de Belém do Pará, no ano de 2012, assisti a uma apresentação de Carimbó, que tinha entre seus instrumentos acompanhantes um banjo-cavaco. "Na festa de São Benedito em Bragança (PA), o Carimbó é conhecido como Retumbão e é uma das danças da Marujada. Lá se usa os tambores grande e pequeno, a cuíca (tambor-onça), o cavaquinho, a rabeca, a viola e o violino" (CASCUDO, 2012, p. 612).

\subsubsection{4 - Cacuriá}

O Cacuriá é uma dança de roda típica maranhense que surgiu na década de 1970, portanto nova, porém já catalogada no Departamento de Turismo do Estado do Maranhão. É apresentada nas comemorações da Festa do Divíno. Alauriano Campos de Almeida, criador do Cacuriá, explica que a dança é uma mistura de samba, marcha, valsa e "chorado" (lundu), o que exige muito esforço físico ${ }^{65}$.

O percussionista maranhense Pial, na entrevista que me concedeu, acrescentou: "O cavaquinho, eles tocam no Cacuriá, que é uma brincadeira com as caixas do Divino. Eles usam o cavaquinho, flauta e às vezes uma rabeca" (NOGUEIRA, 2015). O cavaquinho no Cacuriá é usado no acompanhamento e também faz pequenas intervenções de solos.

\footnotetext{
${ }^{65}$ Informações obtidas no artigo publicado em A Gazeta. São Paulo, 14 de outubro de 1975. Disponível em: http://jangadabrasil.com.br/revista/agosto69/fe69008c.asp. Acesso em: 10/06/2015.
} 
Vimos, portanto, que o cavaquinho é um instrumento eclético e de grande aceitação. Está presente nos centros urbanos e também nas cidades interioranas em diversas regiões do Brasil, participando das mais variadas manifestações culturais e religiosas. 


\section{CAPÍtUlo 3 - UMA NOVA MUDANÇA, EM BREVE, VAI ACONTECER}

\section{1 - A música como processo social num mundo multicultural}

A música está sempre se modificando, é uma arte dinâmica, sujeita aos mais diferentes segmentos culturais. A troca constante de informações abre um leque de possibilidades melódicas, harmônicas e rítmicas, colocado à disposição dos músicos e dos compositores. $\mathrm{Na}$ fronteira entre gêneros ou estilos musicais encontramos elementos que, quando mesclados, possibilitam o surgimento de um terceiro que passa a constituir uma nova fronteira de possibilidades.

Segundo Hermano Vianna, o pesquisador social Bronislaw Malinowski, ao discorrer sobre as relações interculturais, introduz o conceito de transculturalismo de onde emanam ideias que vão ao encontro do que acabamos de expor:

É um processo no qual sempre se dá algo em troca do que se recebe; é um "toma y daca", como dizem os castelhanos. É um processo no qual ambas as partes da equação resultam modificadas. Um processo no qual emerge uma nova realidade, composta e complexa, uma realidade que não é uma aglomeração mecânica de caracteres, nem um mosaico, mas um fenômeno novo, original e independente (MALINOWVISKI apud VIANNA, 2012, p. 171).

Como já vimos, no Brasil, a forma de se tocar o cavaquinho foi sendo construída de acordo com as práticas trazidas do exterior, principalmente, Europa e África. Após algumas décadas de contatos sociais e culturais os resultados se consolidaram em gêneros musicais, o cavaquinho acompanhando tais mudanças, que vieram a moldar uma identidade convertida em um "jeito brasileiro" de tocar o instrumento.

Nesse sentido, as relações estabelecidas no eixo tradição-inovação remetem a um contínuo no qual toda a tradição constitui arcabouço de experimentação para novas práticas, emergindo a inovação nesse contexto. Estabelece-se, assim, um trinômio tradição-inovação(nova) tradição, de forma constante.

Portanto, a inovação, embora atue enquanto ruptura/quebra de uma tradição se estabelece como algo que não é comum, que foge ao convencional, ou transgride os costumes/práticas de uma sociedade. Inovar, enquanto ação, requer uma boa dose de ousadia 
e determinação, estando sujeito à rejeição como também a aceitação, por meio de processos intra e extra-musicais. Esses aspectos se refletem nas práticas de se tocar um instrumento, a partir do momento em que o músico as utiliza enquanto campo de experimentação em processos criativos. Nesse sentido, inovação poderia ser entendida também como renovação.

Sobre inovação considero relevante e oportuno o pensamento do historiador cultural David Couzens Hoy:

Rupturas históricas não ocorrem em todos os lugares para todos ao mesmo tempo. A mesma pessoa, disciplina, ou instituição pode ser tradicional em alguns aspectos, moderna em outros, e pós-modernas em outros ainda. [...] $\mathrm{O}$ pós-modernismo não pode e não deve clamar por ser melhor, mais avançado, ou mais esperto do que tudo que tenha precedido (HOY, 1988, p. 28).

\section{2 - Cavaquinistas no processo tradição-inovação.}

Podemos identificar que as primeiras grandes inovações na prática do cavaquinho brasileiro ocorrem em contextos urbanos, com o surgimento de composições autorais para o instrumento e, em muitos casos, seus registros em partitura. Contrasta assim com as práticas no contexto da cultura oral, principalmente como acompanhamento a manifestações folclóricas, estabelecendo novo patamar ao explorar o legado tradicional de forma experimental, permitindo a identificação autoral de obras para o instrumento.

Diante do exposto, e a partir das fontes bibliográficas e entrevistas concedidas, identificamos um elenco de cavaquinistas que protagonizaram o referido processo de inovação, descrito a seguir.

Galdino Cavaquinho (Galdino Barreto (18- -19-). Instrumentista e compositor que ajudou a propagar os conhecimentos sobre o cavaquinho dando aulas do instrumento no final do século XIX e início do século XX, tendo, entre seus alunos, Mário Cavaquinho. Participou da serenata que o palhaço, cantor, compositor e violonista Eduardo das Neves promoveu para comemorar o retorno de Santos Dumont ao Brasil, em 1903. Alexandre Gonçalves Pinto, em seu livro O Choro: Reminiscências dos Chorões Antigos, escreveu sobre Galdino:

Mestre dos mestres, que se celebrizou com o seu aprendiz Mário, cujo discípulo venceu naquela época todas as dificuldades do instrumento transformando, a sua tonalidade de quatro cordas para cinco, enquanto isso

Galdino, continuava com o seu cavaquinho de quatro cordas tirando 
infinidades de tons e combinações de acordes que me é aqui difícil de descrever, tal é a magia, e a convicção das notas vibradas pela palheta encantada de Galdino, este grande artista, inigualável no meio dos chorões, aonde ele foi o único educador deste instrumento que se chama cavaquinho (PINTO, 1936, p. 54).

Como compositor, nos deixou as polcas: Fera, Flausina, Me Espere na Saída, Na Sombra da Laranjeira, Os Olhos Dela, Ricardina, Saudades e a valsa Recordação (MELLO, 1998, p.312).

Mário Alves Conceição (1861 - 1905). Existe até os dias atuais uma dúvida sobre o seu nome, que pode ser encontrado como Mário Álvares. Instrumentista e compositor tocava cavaquinho de quatro e de cinco cordas, além da bandurria (cordófono semelhante ao bandolim). Também participou da serenata para Santos Dumont. Ficou famoso nas rodas de choro do final do século XIX e início do século XX (MELLO, 1998, p. 482). Entre as rodas de choro que Mário frequentava, uma se dava na casa de Pixinguinha, como consta na Enciclopédia da Música Brasileira: Samba e Choro:

Pai de Pixinguinha e funcionário da Companhia de Correios e Telégrafos, flautista, reunia em casa os grandes chorões da época como Irineu de Almeida, Candinho Trombone, Viriato Figueira, Neco, Quincas Laranjeiras e Mário Cavaquinho (MELLO, 2000, p. 243).

Mário deu aulas de cavaquinho a Pixinguinha e trabalhou no grupo de Catulo da Paixão Cearense e Anacleto de Medeiros (MELLO, 1998, p. 482). Catulo era grande admirador do trabalho que Mário Alves desenvolvia no cavaquinho, como consta no Dicionário Musical Brasileiro:

Célebre no cavaquinho foi Mário Alves, que Catulo Cearense celebrou: Esse instrumento em suas mãos era uma maravilha! Além de executor, foi compositor. Mário, repito, foi assombroso nesse violãozinho de quatro cordas!!! (ANDRADE, 1989, p.124).

Mário Cavaquinho deixou-nos mais de quarenta composições, entre as quais podemos citar o choro Teu Beijo, gravado por Jacob do Bandolim, o maxixe Na Aldeia em parceria com Catulo da Paixão Cearense e gravado por Patrício Teixeira (ALBIN, 2006), a valsa Eulália e o schottisch Soledade. Acredita-se que a música Apanhei-te Cavaquinho, de Ernesto Nazareth, seja uma homenagem a Mário.

Nelson Alves dos Santos ${ }^{66}$ (1895-1960). Tocou no grupo de Chiquinha Gonzaga, ao lado do violonista Tute e do flautista Antônio Mariz dos Passos. Foi um dos fundadores do

\footnotetext{
${ }^{66}$ Disponível em: http://www.dicionariompb.com.br/nelson-alves. Acesso em: 23/12/2013.
} 
Grupo Os Oito Batutas, ao lado de Pixinguinha. Com o grupo, se apresentou em Paris e Buenos Aires, no ano de 1922. Em seu trabalho autoral, encontramos as seguintes músicas: Nem Ela Nem Eu, Ficou Calmo, Eu Vi Você, Não Tem Dúvida, Mi Deixa Serpentina e Mistura e Manda. No dicionário de Ricardo Cravo Albin, encontramos o seguinte:

Instrumentista, compositor. Foi um dos fundadores de Os Oito Batutas (1919) e viajou com o conjunto a Paris em 1922. Autor de clássicos do choro, como a polca Mi Deixa Serpentina (Victor, 1923), gravada pelo conjunto e o choro Mistura e Manda (1934), registrado por Benedito Lacerda (ALBIN, 2006, p. 25).

Aníbal Augusto Sardinha, Garoto ${ }^{67}$ (1915-1955). Virtuoso das cordas, tocava cavaquinho, violão, guitarra, guitarra havaiana, bandolim, banjo e violão tenor. Apesar de ter vivido só quarenta anos, Garoto teve uma intensa carreira artística. No ano de 1931 atuou profissionalmente na Rádio Educadora Paulista (depois Rádio Gazeta), tocando cavaquinho e bandolim no Conjunto Regional. Na mesma década, ao lado do violonista Aymoré, se apresentou em Curitiba, Porto Alegre e Buenos Aires, onde acompanhou Carlos Gardel. De volta ao Brasil, trabalhou com o cantor Silvio Caldas.

No início dos anos 1950, formou dupla com José Meneses, músico que tocava vários instrumentos de cordas. A dupla se apresentava no programa Nada Além de Dois Minutos, de Paulo Roberto, na Rádio Nacional. Ali Garoto trocava de instrumentos sem perder a sequencia das músicas, alternando violão, guitarra, violão-tenor e cavaquinho. Ainda com José Meneses atuou em outros programas, como Ao Som da Viola e Um Milhão de Melodias, nos quais eram solistas da Orquestra da Rádio Nacional, além de terem gravado vários discos (ANTÔNIO \& PEREIRA, 1982, p. 61).

Acompanhou, integrando o Bando da Lua, Carmen Miranda, com a qual viajou para os Estados Unidos. Deixou composições como: Desvairada, Duas Contas, Sinal dos Tempos, Meu Cavaquinho e São Paulo Quatrocentão. Essa última, com letra de Avaré, é uma homenagem aos quatrocentos anos da cidade de São Paulo e vendeu 700 mil cópias. É também de sua autoria a melodia do samba-canção Gente Humilde, que mais tarde, ganhou fama ao receber letra de Chico Buarque e Vinícius de Morais.

José Meneses de França, o Zé Meneses (1921-2014). Multiinstrumentista das cordas tocava violão de seis e sete cordas, violão tenor, bandolim, banjo, cavaquinho, viola de dez cordas, guitarra elétrica, guitarra portuguesa e contrabaixo. Ainda muito jovem compôs sua

\footnotetext{
${ }^{67}$ Todas as informações sobre Garoto foram extraídas do livro: "Garoto Sinal dos Tempos".
} 
primeira música no cavaquinho, o choro Meus Oitos Anos. Como solista, na Ceará Rádio Clube, conheceu o radialista carioca César Ladeira, que convidou o jovem músico para trabalhar na Rádio Mayrink Veiga, no Rio de Janeiro, onde passou a dirigir dois programas semanais, adquirindo grande prestígio como solista. Em 1947, transferiu-se para a Rádio Nacional, onde trabalhou por aproximadamente 25 anos e fez a dupla com Garoto, citada na página anterior (MELLO, 2000, p. 150).

Nos anos 1960, com a queda do prestígio do choro, em decorrência do auge da bossa nova, Zé Meneses fundou o grupo Velhinhos Transviados que, com arranjos satirizados, fez grande sucesso. Segundo o próprio Zé Meneses, em depoimento no documentário Apanhei-te Cavaquinho Episódio I, o grupo gravou 15 LPs (CAZES, 2012).

No ano de 2012, fez turnê pelo Brasil comemorando seus 90 anos de vida e 80 de carreira. Nessa ocasião, nos presenteou com um show na Escola de Música de Brasília, onde atuo como professor de cavaquinho.

Waldir Azevedo (1923-1980) é, sem dúvida, identificado como o mais célebre solista de cavaquinho. A respeito da data de nascimento de Waldir, o cavaquinista Henrique Cazes observou uma curiosidade:

O dia 27 de janeiro tem importância especial para a música, pois foi nele que nasceram Wolfgang Amadeus Mozart e, a exatos 150 anos depois, Radamés Gnattali. Mas há ainda outro aniversariante que fez história... (CAZES, 1998, p. 107).

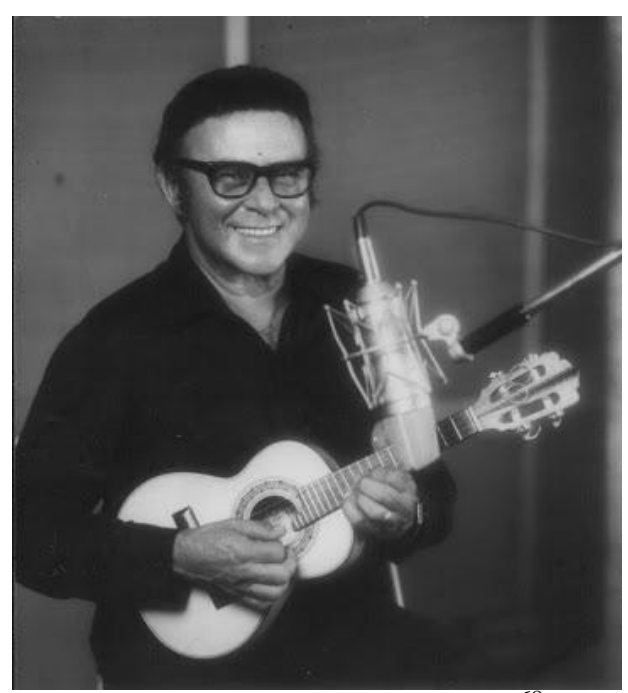

Figura 34 - Waldir Azevedo ${ }^{68}$

\footnotetext{
${ }^{68}$ Disponível em: <http://chorinhonaescola.blogspot.com.br/2011_06_01_archive.html>. Acesso em: 10/03/15.
} 
Waldir desenvolveu uma técnica para tocar o cavaquinho com a qual ele aproveitava de forma plena a sonoridade e facilidades do instrumento. Usava as cordas altas, que apesar de exigir mais força do executante ao pressionar as cordas, aumenta a sonoridade. Tocava sem apoiar a mão direita no cavaquinho e se valia de arpejos, tangendo as cordas com a palheta em uma só direção, efeitos que ajudam na velocidade, no volume e limpeza das notas. Outra técnica que ele usava era a de tocar alternadamente uma corda, ora presa, ora solta, o que fornece uma resposta musical muito boa. Sobre a execução de Waldir, Ana Claudia Cesar complementa:

O outro ponto que deve ser observado é a execução de notas que são tiradas de um arpejo (notas de um acorde executadas uma após a outra) esse recurso é muito explorado pelo instrumentista: as notas da melodia são notas do acorde, e isso faz com que a execução seja mais precisa e rápida, pois a mão está formatada e toca-se cada nota sem movimentar os dedos; este aproveitamento das notas dos acordes para a construção de uma melodia é recorrente em toda a obra de Waldir Azevedo (CESAR, 2013, p. 56).

Sua primeira composição, Brasileirinho, é um choro ligeiro que surge de uma forma curiosa, como nos revela Henrique Cazes:

Um sobrinho pequeno insistiu para que o tio tocasse alguma coisa com um cavaquinho de brinquedo que só tinha uma corda. Nasceu ali o tema de Brasileirinho (CAZES, 2010, p.14).

No comando do Regional da Rádio Clube, Waldir pôde mostrar suas composições e acabou sendo convidado por João de Barro (Braguinha), diretor artístico da Gravadora Continental, para gravar um disco com duas composições suas: Brasileirinho e Carioquinha. Curioso é que, nesse compact disc, o Brasileirinho ficou no lado B, o que indicava maior expectativa de sucesso ao choro Carioquinha, que estava no lado A. Como sabemos, o que aconteceu, foi justamente o inverso.

Somente ter talento não basta para fazer sucesso, é preciso ter sorte, e isso Waldir teve. Primeiramente, a Continental ficava no mesmo prédio da Rádio Clube e, além disso, o seu principal artista de choro, Jacob do Bandolim, acabava de pedir demissão deixando um vazio na gravadora.

O sucesso de Brasileirinho foi tão grande que, no primeiro trimestre de vendagens, Waldir recebeu o equivalente a quatorze anos de trabalho nos seus dois empregos juntos: Light (Cia de Eletricidade) e Rádio Clube. No segundo trimestre, seus ganhos com direitos autorais da música dobraram (BERNARDO, 2004, p. 37-38). 
Em seu documentário Apanhei-te Cavaquinho, Henrique Cazes ilustra a dimensão do sucesso de Brasileirinho:

[...] o pesquisador Jairo Severiano, que chegou ao Rio de Janeiro, vindo do nordeste naquela época, conta que no final de 1949, você ligava o rádio, aqui no Rio, mudava de uma estação pra outra e achava que o rádio estava com defeito. Estava tocando o Brasileirinho em todas as estações (CAZES, 2012).

No ano de 1950, Brasileirinho ganhou letra de Pereira Costa e foi gravado pela cantora Ademilde Fonseca, que voltou às paradas de sucesso. Em seguida, esse chorinho rápido que convidava para dançar, foi gravado por dezenas de artistas no Brasil e no exterior. Brasileirinho tornou-se peça indispensável no repertório dos cavaquinistas e, muitas vezes, é tocado no fechamento das rodas de choro. Pode-se dizer que esta composição é o "Hino Nacional do Cavaquinho".

Depois de um sucesso da magnitude de Brasileirinho, ninguém diria que algo semelhante estava por acontecer. Waldir lança o baião Delicado em dezembro de 1950, que faz um sucesso ainda mais estrondoso: "o baião de Waldir trazia nos primeiros compassos da melodia, a sonoridade que identifica hoje o cavaquinho em qualquer parte do planeta" (CAZES, 2010, p. 21).

Delicado também ganhou letra e foi gravado por Carmen Miranda, cantora que conquistou o Brasil e o exterior na época áurea do rádio. Esse fato ajudou no sucesso da composição. Nos Estados Unidos, em versão instrumental, com a Orquestra Percy Faith, o baião de Waldir esteve em primeiro lugar nas paradas de sucesso (CASTRO, 2005, p. 542). Em uma turnê ao Oriente Médio, Waldir encontrou, em uma feira no deserto, uma caixinha de música que tocava o Delicado.

Outros sucessos de Waldir foram Vê Se Gostas, Chiquita e Pedacinhos do Céu. Este último, composto em homenagem às suas duas filhas Mirian e Marly. Era um choro lento com fraseados românticos e também obteve sucesso de vendagem, "chegando a se tornar uma das gravações mais vendidas durante alguns dias nas lojas de discos do Rio de Janeiro" (BERNARDO, 2004, p. 46).

O que levou Waldir a fazer tanto sucesso foi uma junção de fatores: talento, técnica, criatividade, pioneirismo e inovação; aliados a um meio social propício, num momento favorável e sorte. $\mathrm{O}$ auge dos Regionais nas rádios deixou em evidência todos os que deles faziam parte e Waldir estava lá. A evolução das técnicas de gravação proporcionou discos de 
melhor qualidade sonora, que certamente corroboraram para o sucesso de Waldir Azevedo. No entanto, todos esses fatores, talvez, não teriam surtido efeito se Waldir não estivesse no lugar certo, na hora certa, fazendo a coisa certa.

É interessante notar que Waldir compunha suas músicas com apenas duas partes, o que foge à regra tradicional do choro em três partes, na forma rondó, na qual se expõe a primeira parte (A), em seguida a segunda (B), volta-se para a primeira (A), toca-se a terceira (C) e, por fim, finaliza-se com a primeira (A).

Alguns anos antes, Pixinguinha teria sido criticado por compor o choro Carinhoso com duas partes e influência norte-americana, como nos confirma o crítico Cruz Cordeiro: "Parece que o nosso popular compositor ainda muito influenciado pela música do jazz [...] nesse seu choro, cuja introdução é um verdadeiro fox-trot, não nos agradou" (CORDEIRO, 1930, p. 13). ${ }^{69}$

No ano de 1971, Waldir transferiu-se pra Brasília, onde sofreu um acidente com um cortador de grama, quando teve decepada a ponta do dedo anelar esquerdo. Feito o implante e recuperado, Waldir voltou a tocar. Em agradecimento, compôs a música Minhas Mãos Meu Cavaquinho, gravada em LP do mesmo nome. Essa composição possui melodia suave com andamento lento, que termina com um trecho da Ave Maria de Bach e Gounod.

Waldir explorou de tal forma as facilidades sonoras do cavaquinho que acabou criando a impressão de que era fácil chegar àquele resultado. Assim, logo apareceram vários imitadores. "Dizem que havia um no bairro de Jacarepaguá que tocava tão parecido com ele, que Waldir o usava como substituto em programas de rádio" (CAZES, 2010, p. 47).

Todos os cavaquinistas contemporâneos a Waldir e também aqueles das gerações seguintes, carregam, no modo de tocar, a influência do "grande mestre."

Entre os cavaquinistas que herdaram a técnica de Waldir, destaco o gaúcho Avendano Júnior $^{70}$ (1939-2012). Fã confesso e amigo de Waldir, com quem apreendeu, pessoalmente, os conhecimentos que o mestre desenvolvera. Um ouvinte de choro, desavisado, ao ouvir Avendano, pode pensar que está ouvindo o próprio Waldir. A sonoridade limpa e forte, o aproveitamento das facilidades do instrumento, são algumas das heranças que Avendano

\footnotetext{
${ }^{69}$ Disponível em: <revistaphonoarte.com>. Acesso em: 15/03/2015.

${ }^{70}$ Informações sobre Avendano disponíveis nos sites: http://pelotascultural.blogspot.com.br/2012/06/avendanojunior-viveu-para-o-cavaquinho.html e http://avendanojunior.musicblog.com.br/. Acesso em: 08/02/2015.
} 
soube assimilar. No LP Minhas Mãos Meu Cavaquinho, Waldir gravou a música Assim Traduzi Você, uma composição de Avendano Júnior.

O carioca Valmar Gama de Amorin (1949) começou sua carreira profissional nos anos sessenta, trabalhando em conjuntos regionais em diversas emissoras de rádio. Foi cavaquinista de centro no Regional de Abel Ferreira e no Regional de Altamiro Carrilho, em 1970. Foi convidado por Waldir Azevedo para participar do disco Minhas Mãos Meu Cavaquinho (1976), apresentando-se com o mestre por todo o Brasil, ocasião em que aprendeu as técnicas de execução no cavaquinho desenvolvidas por Waldir.

Amorim tira um som claro do instrumento e possui uma carreira admirável. Acompanhou cantoras famosas como Ademilde Fonseca, Elizeth Cardoso, Beth Carvalho e Alcione. Em 1985, participou do Conjunto Época de Ouro como solista, do primeiro Festival Free Jazz. Integrou a Orquestra da TV Globo, onde teve a oportunidade de participar de trilhas sonoras de novelas e casos especiais. Lançou o CD Um Cavaquinho para Todos os Gostos, com composições próprias e texto de apresentação de Ricardo Cravo Albin (ALBIN, 2006, p. 33).

Em sua obra como compositor, constam as músicas Cavaquinho Pantaneiro, Baião Árabe, Em Tempo de Bach, Saudades de Portugal, Baião Japonês, Balançado, Barroco e Cheio de Bossa.

O paulista Roberto Barbosa (1938), o Canhotinho ${ }^{71}$, foi considerado pelo próprio Waldir Azevedo seu sucessor. Integrante do grupo de samba e choro Demônios da Garôa, participou também do regional do flautista Carlos Poyares. Barbosa gravou diversos discos entre os quais Tributo a Waldir, Valsas Inesquecíveis e Pedacinhos do Céu.

Entre suas composições, registro o choro Franciscos, o frevo De São Paulo a Recife e o Baião 2000. Esta última música foi gravada no seu disco de maior sucesso, uma homenagem póstuma a Waldir, Luz e Sombra - O LP que Waldir Azevedo Não Gravou. Estava tudo pronto para que Waldir gravasse esse LP, as músicas selecionadas, os músicos ensaiados. Porém, por complicações cardíacas, o destino quis que ele partisse antes de fazê-lo. Assim Canhotinho foi convidado para substituí-lo.

\footnotetext{
${ }^{71}$ Dados sobre Canhotinho em: <http://opontodosmusicos.blogspot.com.br/2014/11/canhotinho.html〉. Acesso em: 08/02/2014.
} 
Waldir Silva $^{72}$ (1931-2013), mestre no cavaquinho, chegou a se apresentar com seu xará Waldir Azevedo, além de se destacar com seu conjunto em bailes e shows por mais de 30 anos. Com o projeto Minas ao Luar, em parceria com o SESC, levou seu cavaquinho a praças de todo o estado de Minas Gerais por mais de 20 anos, fato que contribuiu para sua projeção e fama nacional. Grande compositor, Waldir Silva também se preocupava em registrar obras de mestres consagrados como Zequinha de Abreu e Ernesto Nazareth. Deixou uma discografia de mais de 35 discos entre serestas, choros, sambas, mambos, boleros e cha-cha-chas. Entre suas composições, destaco Um Cavaquinho no Mambo, Cavaquinho Cha-cha-chando, parceria com Rodolfo Marques, e Telegrama Musical, com Hélio Zico, que recebeu elogios do então presidente Juscelino Kubistschek, um apaixonado por serestas.

Ormindo Fontes de Melo ou Toco Preto ${ }^{73}$ (1933), ganhou fama nos tempos do rádio como solista e acompanhador. Em sua carreira profissional trabalhou nas Rádios Mayrink Veiga, Tupi e Tamoio. Como cavaquinho de centro, trabalhou com o sambista Roberto Ribeiro e acompanhou grupos de música nordestina. Em 1977, ao lado de Zé da Velha (trombone), Josias Nunes (flauta), Rubens (trompete), Valdir (violão 7 cordas), Jairo (violão), Parada (surdo) e Jayme (pandeiro) participou do Grupo Chapéu de Palha, com o qual gravou dois discos, onde foram incluídas composições suas, entre as quais Tema Chapéu de Palha. $\mathrm{O}$ grupo se apresentava a caráter, representando o malandro carioca, camisa listrada, calças e sapatos brancos e chapéu de palha com abas rígidas.

Entre seus discos gravados, em que Toco Preto interpreta clássicos da música brasileira, elencamos o LP Chora Cavaquinho, com as faixas Banho de Cheiro (Carlos Fernando), Manhã de Carnaval (Luiz Bonfá e Antônio Maria) e Sonho Meu (Dona Yvone Lara e Délcio Carvalho) e o CD MPB em Chorinho, que traz Pecado Capital (Paulinho da Viola), A Noite do Meu Bem (Dolores Duran) e Proposta (Roberto Carlos e Erasmo Carlos).

Eli Monteiro da Silva (1935) ou Eli do Cavaco. Autodidata, começou a tocar cavaquinho com 15 anos em Campos (RJ), sua cidade natal. Transferiu-se para Brasília em 1961, onde permanece até os dias de hoje. Tocou em vários lugares da nova capital onde o choro se instalava como o Restaurante Amarelinho, com o Regional de Bide da Flauta e

\footnotetext{
${ }^{72}$ Dados sobre Waldir Silva por Ailton Magioli, Repórter Cultural do Jornal Estado de Minas, enviados no email Waldir Silva: O Seresteiro Sai de Cena em 02/09/13, repassado em 03/09/13 por Jorge Cardoso Moura somdebandolim@yahoo.com.br e recebido por carrapadocavaquinho@yahoo.com.br, adicionados aos dados encontrados no Dicionário Cravo Albin, disponível em: <http://www.dicionariompb.com.br/waldir-silva/dadosartisticos>. Acesso em: 05/02/2015.

${ }^{73}$ Dados sobre Toco Preto: http://www.dicionariompb.com.br/toco-preto. Acesso em: 05/02/2015.
} 
Pernambuco do Pandeiro. Tocou também no Hotel Araraquara, na famosa feijoada, que era ponto de referência do choro em Brasília, por onde passaram músicos do quilate de Zé da Velha, Dominguinhos e Carlos Poyares e ainda no Bar Calipso e no Bar Cavaquinho. Nesse último, em uma de suas apresentações, encontrava-se no público Waldir Azevedo, que estava procurando músicos para integrar seu novo conjunto (TEIXEIRA \& RIOS, 2012).

Eli, que estudava a fundo a obra de Waldir, passou a atuar como cavaquinista de centro, na nova formação de músicos que iria acompanhar o compositor de Brasileirinho, em suas novas investidas, agora como morador de Brasília (idem).

Eli do Cavaco participou dos primórdios da fundação do Clube do Choro de Brasília, ao lado de Odette Ernest Dias e Bide (flautas), Hamilton Costa (violão), Dudu (violão 7 cordas) e Carlinhos (violão7 cordas), Pernambuco do Pandeiro e seu colega de instrumento Valdeci. Como compositor deixou choros, valsas e guarânias (idem).

José Siqueira de Alcântara, o Siqueira do Cavaco ${ }^{74}$, (1937) nasceu em Recife. Ainda muito jovem, passou a integrar o conjunto de Pixinguinha, atuando como cavaquinho de centro, levado pelo violonista Nelson Velha Guarda, com quem Siqueira já tocava profissionalmente como solista.

Tocou ao lado de João da Baiana, Donga e Pixinguinha, no Grupo Velha Guarda. Integrou vários conjuntos musicais e regionais de choro, no Rio de Janeiro, além de participar da Orquestra Tabajara do maestro Severino Araújo e ainda da Velha Guarda da Mangueira. Atuou em programas na Rádio Nacional, Rádio Metropolitana, Rádio Globo e TV Rio.

No ano de 2004, o Grupo Chapéu de Palha, onde o músico já havia atuado, gravou de sua autoria Tributo a Edson Sete Cordas, com participação do próprio Siqueira do Cavaco. No Recife, teve outra composição gravada pelo Sexteto Capibaribe: Primavera, no CD Choros Penambucanos.

Em 2012, foi a Lisboa onde ministrou oficina de cavaquinho brasileiro, com o apoio do Clube de Choro de Lisboa. Com mais de 450 composições, só aos 76 anos, gravou seu primeiro CD, Entre Nós, com 14 composições próprias, produzido pelos cavaquinistas Wellington Monteiro e Pedro Cantalice.

\footnotetext{
${ }^{74}$ Dados sobre Siqueira do Cavaco, disponíveis em; http://www.dicionariompb.com.br/siqueira/dados-artisticos. Acesso em: 05/02/2015.
} 
Segundo depoimento do músico Valmar Amorim, no texto que acompanha o $\mathrm{CD}$, Siqueira consegue extrair do cavaquinho uma sonoridade própria, com "fraseados diferentes", associado a uma harmonia sofisticada e moderna, criando um modelo não convencional dentro de uma música tradicional, demonstrando que o tradicional e o moderno podem conviver em perfeita harmonia.

Paulo César Batista de Faria (1942), o Paulinho da Viola, ficou famoso como compositor de sambas, mas também compôs choros ao cavaquinho, tais como Beliscando, Choro Negro, Abraçando Chico Soares, Oração de Outono, Inesquecível, Choro de Memórias, Rosinha Essa Menina, Sarau Para Radamés e Um Sarau Para Raphael.

Sobre sua vivência precoce com o gênero musical choro, o próprio Paulinho comenta, no livro Canta Brasil, de Carlos Galilea Nin:

Nasci numa roda de choro e o samba entrou na minha vida muito tempo depois, quando fiquei famoso com minha composição Foi um Rio que Passou em Minha Vida (1969), lançada pela Portela, minha escola (NIN, 1990, p. 91).

No ano de 1973, ao lado de Sérgio Cabral, se apresentou no Teatro da Lagoa (RJ) acompanhado pelo Conjunto Época de Ouro (MELLO, 2000, p.186). Esse show ajudou a reavivar o choro, que esteve esquecido nos anos 1960, durante o ápice da Bossa Nova.

Na sua composição Choro Negro, nota-se o sotaque do jazz em melodia lenta com harmonia sofisticada. Em Sarau Para Radamés, choro cheio de breques, com um toque erudito, o compositor mistura o cavaquinho com pandeiro, piano, flauta e clarinete. Um ouvinte apreciador de choros tradicionais poderá questionar se realmente essa composição é um choro.

Henrique Leal Cazes (1959). Instrumentista, compositor, arranjador, produtor e pesquisador. Toca cavaquinho, bandolim, violão, violão-tenor, banjo e viola caipira (ALBIN, 2006, p. 180). Foi no cavaquinho que se destacou como um dos instrumentistas mais renomados da atualidade.

Na segunda metade da década de 1970 participou do Grupo Coisas Nossas, que interpretava músicas de Noel Rosa. Em viajem ao Rio de Janeiro, acompanhei um show do grupo. A alta qualidade dos arranjos musicais e da execução dos músicos, entremeados a passagens curiosas da vida de Noel narradas por Cazes, proporcionaram um belíssimo espetáculo ao público. 
Trabalhou com o maestro Radamés Gnattali na Camerata Carioca, onde se desenvolvia um trabalho novo, que utilizava o cavaquinho para tocar desde Vivaldi até músicas de autores contemporâneos (CAZES, s/d, p. 08). A respeito da Camerata Carioca, Ricardo Cravo Albin, afirma:

Grupo instrumental. Joel do Nascimento, bandolim; Raphael Rabello, violão de sete cordas; Luciana Rabello, cavaquinho; Maurício Carrilho, violão; Celsinho Silva, pandeiros; Luís Otávio Braga, violão. Em outras formações: João Pedro Borges, violão de sete cordas; Henrique Cazes, cavaquinho; Beto Cazes, pandeiros; Edgar Gonçalves, sopros. Foi criado em 1979 para acompanhar a suíte Retratos de Radamés Gnattali. Interpretando um repertório de obras das áreas erudita e popular, lançou em 1982, o LP Vivaldi \& Pixinguinha (ALBIN, 2006, p.140).

Fundou a Orquestra Pixinguinha (1988), formada por vários metais, cavaquinho, violão e percussão, que interpretava composições do mestre Pixinga com uma nova roupagem. Participou da criação da Orquestra de Cordas Brasileiras (OCB) formada basicamente por instrumentos de choro, trabalho que tive a oportunidade de ouvir pessoalmente e que me agradou muito, não só pela sonoridade, como também pela originalidade. Sobre a OCB, Cazes nos deixa seu depoimento:

Sugeri uma formação que considerava ideal para uma orquestra, a princípio uma orquestra de choro: quatro bandolins, dois cavaquinhos, duas violas caipiras, dois violões, um violão de sete cordas, contrabaixo acústico e dois percussionistas. [...] a OCB trouxe uma mistura já testada anteriormente por Radamés no início da Camerata: música barroca, no caso Concerto Brandemburguês $n^{\circ} 3 \mathrm{em}$ sol maior, J.S.Bach e uma seleção dos grandes compositores do choro como Jacob do Bandolim e Ernesto Nazareth, entre outros (CAZES, 1998, p.195).

Prestes a completar uma década de sua fundação, a OCB, com dificuldades para se manter, encerrou suas atividades. Três anos depois, com proposta de trabalho semelhante, surge o octeto Camerata Brasil. Sobre o acontecimento, Cazes nos esclarece: "Mais enxuta e com nível técnico mais homogêneo, a Camerata Brasil é uma consequência apurada da OCB” (CAZES, 1998, p. 196).

Ao longo de sua carreira como solista, gravou vários discos, entre os quais: Henrique Cazes, Tocando Waldir Azevedo; Waldir Azevedo, Pixinguinha, Hermeto \& Cia; Desde que o choro é choro e Relendo Waldir Azevedo. Como pesquisador escreveu, entre outros, os livros Escola Moderna do Cavaquinho; Choro do Quintal ao Municipal; Waldir Azevedo, Coleção Folha Raízes da Música Popular e foi protagonista no documentário, Apanhei-te Cavaquinho, gravado no Brasil, em Portugal, em Cabo Verde e no Havaí. Todas essas fontes foram usadas 
nesta pesquisa. Entre suas composições, destaco Desengomado, Mitsuro do Cavaco e Estudo de Arpejo $n^{o} 1$.

Jayme Vignoli ${ }^{75}$ (1967). Começou a tocar cavaquinho aos treze anos e com dezessete já atuava profissionalmente. É compositor e arranjador. Foi um dos fundadores da Orquestra de Cordas Brasileiras e integrou a Orquestra de Música Brasileira, regida pelo maestro Roberto Gnattali, sobrinho de Radamés Gnattali. Vignoli participou do grupo de choro Água de Moringa, que obteve grande aceitação de público no Brasil, França e Estados Unidos. Acompanhou artistas famosos como Paulinho da Viola, Joel Nascimento, Nélson Sargento, Monarco, Raphael Rabello, Chiquinho do Acordeon, Carlos Malta, Guilherme de Brito, Nei Lopes, Martinho da Vila, Élton Medeiros, Mestre Marçal, Adriana Calcanhoto, Wagner Tiso, Eduardo Dusek, Walter Alfaiate, Cristina Buarque, Rildo Hora, Beth Carvalho, Carlinhos Vergueiro, Miúcha, Olívia Byington, Jards Macalé, Ivor Lancellotti, Dona Ivone Lara, Zeca Pagodinho, Dudu Nobre, Christina Buarque e Paulo Moura.

Seu trabalho como cavaquinista e arranjador tem recebido as mais calorosas críticas. Nos anos de 2013 e 2014, veio a Brasília dividir seus conhecimentos sobre o cavaquinho no Curso de Verão da Escola de Música de Brasília. No seu trabalho autoral, aponto Moleque da Penha ${ }^{76}$.

Luciana Maria Rabello Pinheiro ${ }^{77}$ (1961), cavaquinista, compositora e produtora. Ainda muito jovem fundou, o lado de seu irmão Rafael Rabello, o grupo Os Carioquinhas que, em sua última formação, contava com o violonista Maurício Carrilho e com o pandeirista Celsinho Silva. Em entrevista à revista americana Brazzil, Luciana fala do surgimento do grupo:

Ficamos com a idéia fixa de fazer um conjunto. Conhecemos o Paulinho do Bandolim, o Théo (violão), e o Mário (pandeiro). Faltava o cavaquinho. Raphael, sem a menor cerimônia, pediu que eu deixasse o violão de lado e tocasse o cavaquinho para poder formar o grupo, pois não tinha mais ninguém [riso]. Grande decisão de um visionário. [...] Mauricio entrou para o conjunto no lugar do Théo. Conhecemos o clarinetista Celso Cruz e o Celsinho do Pandeiro, que também se juntou a nós (RABELLO, 2000).

\footnotetext{
${ }^{75}$ Dados sobre Jayme Vignoli disponível em: http://www.samba-choro.com.br/artistas/jaimevignoli. Acesso em: 31/07/2014.

${ }^{76}$ Disponível em https://www.youtube.com/watch?v=1i-G-dJ8mQQ. Acesso em: 14/05/15.

${ }^{77}$ Dados sobre Luciana Rabello disponível em: http://www.dicionariompb.com.br/luciana-rabello/dadosartisticos. Acesso em: 31/07/2014.
} 
O grupo chegou a gravar o LP Os Carioquinhas do Choro (1977), pela Som Livre, porém, se desfez um ano depois. Ao tomar conhecimento do fato, o bandolinista Joel Nascimento, convidou a base do então extinto Os Carioquinhas para participar da versão para Regional de Choro, da suíte Retratos de Radamés Gnattali, originalmente composta para bandolim e orquestra. O resultado da experiência Luciana descreve assim:

Radamés ficou entusiasmado e resolveu escrever outros arranjos para o grupo e ele próprio disse que queria tocar com aquela formação. Hermínio Bello de Carvalho estava nessa festa e organizou aquilo que ele viu acontecer na sua frente. Criou-se assim, a Camerata Carioca, que batizada e impulsionada profissionalmente pelo Hermínio, estreou para o público em agosto de 1979 num belo show chamado Tributo a Jacob, que também foi gravado em estúdio (ibidem).

Luciana Rabello permaneceu por pouco tempo na Camerata Carioca, de onde saiu por sentir necessidade de caminhar sozinha. Ao longo de sua carreira, Luciana tocou com diversos artistas renomados e fez shows pela Europa:

Trabalhei com muitos cantores e como solista em alguns projetos. Trabalhei com Elizeth Cardoso, Paulinho da Viola, Francis Hime, Chico Buarque, Martinho da Vila, Baden Powell, Toquinho, Copinha, Abel Ferreira, e mais uma dezena de outros artistas, como músico de estúdio e, algumas vezes, de shows. Viajei para Europa em duas tournées de três meses de duração cada uma, durante dois anos seguidos (ibidem).

Segundo o Dicionário Cravo Albin on line, Luciana lançou disco solo em 2000 com oito composições próprias e quatro composições dedicadas a ela.

Jorginho Gomes (1955?). Apesar de ter como seu primeiro instrumento a bateria, toca percussão, bandolim e cavaquinho. Ex-integrante do grupo Os Novos Baianos, compôs, no cavaquinho, a música Um Bilhete Pra Didi, que foi gravada no disco Acabou Chorare, 1972. O tema da música é um baião com forte apelo rítmico, que acaba evoluindo para um rock, sugerindo uma maneira de tocar o cavaquinho, inspirado na técnica usada nas violas nordestinas, com a qual se toca uma corda do instrumento ora presa, ora solta ${ }^{78}$. De fato, segundo depoimento do irmão do compositor, o guitarrista Pepeu Gomes ${ }^{79}$, essa música foi toda feita em uma corda só. O cantor e compositor Moraes Moreira ${ }^{80}$ considera a composição de Jorginho como o Brasileirinho dos Novos Baianos.

\footnotetext{
${ }^{78}$ Waldir Azevedo já utilizava essa técnica, mas não com o sotaque das violas caipiras nordestinas.

${ }^{79}$ Disponível em; http://jornalggn.com.br/tag/blogs/bilhete-pra-didi. Acesso em: 28/03/2015.

${ }^{80}$ Disponível em: https://www.youtube.com/watch?v=kXD5ZyGQAn0. Acesso em: 28/03/2015.
} 


\section{3 - Aspectos sobre os processos de tradição-inovação-(nova) tradição}

Para além de sua inserção no samba e choro e, em regiões específicas, em manifestações e práticas folclóricas, o cavaquinho brasileiro introduz-se em gêneros musicais e espaços musicais inovadores, normalmente não assimilados aos seus espaços tradicionais.

A Camerata Carioca, liderada pelo bandolinista Joel Nascimento, em parceria direta com Radamés Gnattali (CAZES, 2014), introduziu o cavaquinho de Luciana Rabello e, em seguida, o de Cazes, em peças de Vivaldi e outros compositores contemporâneos. A Orquestra de Cordas Brasileiras e a Camerata Brasil deram segmento a essa proposta de trabalho no Rio de Janeiro. Hoje, no Curso de Bacharelado em Cavaquinho da UFRJ, o trabalho com música erudita continua como confirma Henrique Cazes:

Além da Camerata Carioca, que além de choro tocava de Vivaldi a Leo Brouwer, havia a Orquestras de Cordas Brasileiras e a Camerata Brasil, nas quais o cavaquinho foi usado em experiências camerísticas mais arrojadas. Mas, como instrumento solista, só a partir do curso de Bacharelado e das obras dos compositores desta Escola de Música, como Ernani Aguiar, Alexandre Schubert e Carlos Almada, que o cavaquinho ganha um repertório de música de concerto (CAZES, 2014).

$\mathrm{Na}$ entrevista ao músico e arranjador Marco César de Oliveira Brito, fundador do primeiro curso de bandolim e cavaquinho em conservatório de música no Brasil, me foi revelado que também em Pernambuco o cavaquinho é aproveitado na música erudita:

Aqui em Pernambuco usamos o cavaquinho nas orquestras de cordas: Orquestra de Cordas Dedilhadas de Pernambuco, Oficina de Cordas de Pernambuco e Orquestra Retratos. Instrumentado como solista e base rítmico-harmônica, erudito-popular e armorial. [...] No Quinteto de Cavaquinho do Conservatório Pernambucano de Música o instrumento é tratado como erudito, tocando peças arranjadas para a formação específica (BRITO, 2015).

O cavaquinho está presente na Banda Mundo Livre S/A, que faz parte do movimento Manguebeat, onde o rock foi misturado com ritmos de Pernambuco (BRITO, 2015). O cavaquinista brasileiro Thatá, em entrevista ao programa Casa do Brasil $\mathrm{TV}^{81}$, mostra que o cavaquinho pode ser utilizado no bolero, no rock e no reggae. Bernardo Cascarelli Jr., o $\mathrm{Xixa}^{82}$, conhecido como solista, centrista e compositor de choros, levou o cavaquinho para a música sertaneja ao participar dos discos Caipira (1981) e Violeiro (1982) de Rolando

\footnotetext{
${ }^{81}$ Disponível em: https://www.youtube.com/watch?v=8F24Z3BzudE . Acesso em: 05/03/2015.

${ }^{82}$ Dados sobre Xixa em: http://www.dicionariompb.com.br/xixa/dados-artisticos. Acesso em: 06/04/2015.
} 
Boldrin e também do LP Pena Branca e Xavantinho - Uma Dupla Brasileira (1994). O músico e arranjador, João Ferreira utiliza o cavaquinho na banda de reggae Natiruts. Em entrevista que me foi concedida na Escola de Música de Brasília, o músico fala sobre essa experiência:

A gente estava fazendo a produção de um DVD acústico, era um projeto que não tinha a guitarra, era com piano, violão e sopros. E aí, tinha uma questão que era o seguinte: no reggae se usa muito o wahwah, pedal de guitarra que é bem característico do gênero e, eu pesquisando, notei que esse pedal não podia faltar no trabalho porque tem a questão do reggae, que precisa ter, ou melhor, não precisa, mas é bom que tenha. E sem a guitarra, o cavaco interage com ele (o wahwah) melhor do que com o violão, talvez por ser mais agudo e ter mais ataque, devido as cordas de aço. Então simplesmente liguei o wahwah no cavaquinho e a sonoridade ficou legal, ficou bacana, o pessoal da banda gostou... E como eu sabia da pré-disposição da banda em rodar muito com esse show, inclusive fora do Brasil, o cavaquinho traria um aspecto de brasilidade ao som da banda. O projeto foi bem sucedido, as pessoas gostaram bastante, os fãs da banda, o pessoal do samba... É isso! (FERREIRA, 2015).

Hermeto Pascoal (1936), conhecido por seu trabalho instrumental inovador, toca vários instrumentos, entre os quais o cavaquinho, com o qual compôs Desencontro Certo, música com traços jazzísticos, onde trava uma conversa com a viola caipira de Heraldo Dumonte. Foi ouvindo essa música que descobri que a tonalidade de mi bemol é boa para solar no cavaquinho, já que permite ao executante usar três cordas soltas, o que facilita a interpretação. No entanto, creio que Hermeto tenha sido o primeiro músico a utilizar essa tonalidade no instrumento. Outra composição do músico que me chamou atenção é Sorrindo, melodia com raízes no choro e no jazz.

O carioca Júnior Fernandes (1988) é um cavaquinista da nova geração dono de uma técnica apurada e compositor de peças para cavaquinho como Puro Jazz, Jazz no Cavaco Estudo $n^{o}$ 1, Jazz no Cavaco Estudo $n^{o}$ 2. Essas composições trazem as frases musicais características do jazz, não apresentam traços de música brasileira e, soladas no cavaquinho, produzem uma sonoridade que soa muito bem e é uma novidade. Em entrevista, via internet, Júnior Fernandes confessou suas influências:

Eu toco um instrumento muito brasileiro, porém eu gosto muito de música americana. Um disco que me influenciou muito foi o G3 de guitarra com Joe Pass e George Benson. Eu acredito que uma nova era chegou, uma era de liberdade na qual você pode se expressar com aquilo que sente e sem medo de ser feliz. Tudo aquilo que vem da alma, de verdade! (FERNANDES, 2015). 
Outra composição de Fernandes, Cavaco Soul Choro, traz características inovadoras ao misturar dois gêneros musicais de países diferentes, ambos com raízes negras, o soul americano e o choro brasileiro. O resultado é música boa com sonoridade diversa.

Em Brasília, cidade onde moro, podemos sentir que a mistura cultural acontece de modo muito intenso. A capital recebeu e recebe imigrantes de todas as partes do Brasil e aglomera aqui a cultura de todas as regiões do país. Sendo o Brasil a mistura de dimensões culturais distintas, então Brasília é a mistura da mistura cultural. Essa atmosfera multifacetada é um terreno fértil para o surgimento de um jeito novo de tocar.

O grupo brasiliense Liga Tripa, composto por músicos e poetas, apresenta um trabalho composicional próprio. Além de tocar ritmos tradicionais brasileiros, o grupo desenvolveu um ritmo novo, um 6/8, que é uma mistura de rock, reggae, balada e iêiêiê, chamado ligada. Os instrumentos usados são dois violões (Aldo Justo e Sérgio Duboc), um cavaquinho (Carrapa do Cavaquinho), uma flauta (Toninho Alves), percussão (Fino), um contrabaixo monocórdio acústico (Calouro) e vozes (todos).

Quem vem desenvolvendo uma técnica surpreendente e um jeito ousado de tocar é o músico Marcio Marinho de Souza (1984). Entrosado com o instrumento como se fosse extensão de sua mão, ele é dono de vasto repertório e improvisa com muita facilidade, num estilo que mistura frases musicais da música brasileira com o jazz. Para Marinho, o cavaquinho não tem fronteiras, como nos relata Humberto Pontes no blog do cavaquinista ${ }^{83}$ :

Márcio Marinho se destaca como revelação em virtude do novo conceito, da nova "cara" que vem construindo para o cavaquinho. Sua maneira de tocar faz a química das linguagens jazz/choro com doses de virtuosismo, abrindo horizontes e transformando o cavaquinho num instrumento surpreendentemente sem barreiras, que se encaixa perfeitamente em qualquer estilo musical. Marcio Marinho, 26 anos de idade, cavaquinista de cinco cordas é um dos maiores nomes do instrumento no Brasil na atualidade (PONTES, 2011).

Segundo informações enviadas por e-mail ${ }^{84}$ pelo próprio Marinho e comprovadas pela mídia, em 2004 o músico foi convidado por Reco do Bandolim para atuar como cavaquinho de centro no Choro Livre, grupo oficial do Clube do Choro de Brasília, onde teve a oportunidade de tocar com músicos famosos como Dominguinhos, Hermeto Pascoal, Derico,

\footnotetext{
83 "Márcio Marinho". Por Humberto Pontes, disponível em $\underline{\text { http://marcio- }}$ marinho.blogspot.com.br/2011/10/marcio-marinho-frango-do-cavaco.html. Acesso em: 31/07/2014.

84 SOUZA, Márcio Marinho de. Entrevista e Release para Carrapa. Mensagem enviada por frangodocavaco@gmail.com e recebida por carrapadocavaquinho@yahoo.com.br em 25/02/15.
} 
Osvaldinho do Acordeão, Carlos Malta, Carlos Henrique Machado, Paulo Sérgio Santos, Paulo Moura, Sombrinha, Danilo Brito, Zé da Velha e Silvério Pontes entre outros. Nessa época começa sua carreira internacional, com viagens para Argentina, Peru, Uruguai, Bolívia, México, Dubai, França, Alemanha, Tunísia, Portugal, Espanha, China e Estados Unidos (SOUZA, 2015).

A partir de 2007, em busca de inovação, propôs a Rafael dos Anjos (violão) um projeto mais arrojado reunindo a originalidade e idiossincrasias daqueles que formariam o quarteto Galinha Caipira Completa, em 2008. Também tomam parte nesse trabalho Rafael dos Santos (bateria) e Hamilton Pinheiro (baixo). Esse projeto é bem-sucedido, recebendo em 2009 o Prêmio Pixinguinha, patrocinado pela Funarte, o que possibilitou a gravação de seu primeiro CD. Márcio Marinho continua atuando como cavaquinista de centro no Choro Livre e paralelamente segue com seu trabalho próprio.

O cavaquinista brasiliense Pedro Vasconcelos (1982) também desenvolve um trabalho inovador em suas composições, com harmonias elaboradas e melodias docemente “jazzificadas”. Vasconcelos ${ }^{85}$ já acompanhou e gravou com vários artistas brasileiros. Formou o Trio Aquário, ao lado do baixista Eduardo Belo e do violonista Rafael dos Anjos, com o qual registrou o CD Primeiro. Com o pianista Ricardo Nakamura, gravou o CD Transparente e com o baixista e cantor Ebinho Cardoso, A Comédia do Coração. Nos três trabalhos, Pedro assina a maioria das composições e atua como solista de cavaquinho. Atualmente, trabalha também em grupos de samba, choro e música instrumental brasileira e como diretor musical e arranjador.

Se o leitor me permite, sem falsa modéstia, gostaria de acrescentar que eu próprio, Luis Carlos Orione de Alencar Arraes ou Carrapa do Cavaquinho (1961), procuro desenvolver um estilo diferente em minhas composições, fato que fomentou meu entusiasmo para fazer esta pesquisa. No meu trabalho composicional, nota-se que existe uma base fundamentada no choro tradicional, com influências do frevo, do baião, do jazz, do rock, da música árabe, música indiana, etc. Essas influências são percebidas nas linhas melódicas.

Por fim, não se pretendeu aqui esgotar os protagonistas de tais práticas, mas apontar como a atividade de trocas e processos não cessa. O surgimento do novo é inevitável e, segundo o etnomusicólogo, Bruno Nettl, “a música expressa um subtexto cuja mensagem é

85 “Pedro Vasconcelos”. Disponível em http://pedrovasconcellos.tnb.art.br/. Acesso em: 01/08/2014. 
determinada por questões como a cultura, classe, gênero e personalidade" (NETTL, 1994, p. 139).

Entre os extremistas conservadores existe o receio de que o surgimento da inovação venha comprometer o gênero tradicional, o qual está consolidado, tocado por todo o Brasil e também no exterior. A inovação ora ocorre de maneira paralela, ora se cruza com o convencional, promovendo outros planos de criação. 


\section{CONSIDERAÇÕES FINAIS}

No decorrer desta pesquisa, vimos que o cavaquinho emprestou sua sonoridade aguda e seu ritmo marcante a gêneros musicais importados, que "misturados" ajudaram na atual constituição da nossa música. Para além de sua inserção no samba e no choro e, em regiões específicas, em manifestações e práticas folclóricas, o cavaquinho brasileiro introduz-se em gêneros musicais e espaços musicais inovadores normalmente não assimilados aos seus espaços tradicionais.

Como vimos no terceiro capítulo, podemos identificar que as primeiras grandes inovações na prática do cavaquinho brasileiro ocorrem em contextos urbanos, com o surgimento de composições autorais para o instrumento e, em muitos casos, seus registros em partitura. Contrasta assim com as práticas no contexto da cultura oral, principalmente como acompanhamento a manifestações folclóricas, estabelecendo novo patamar ao explorar o legado tradicional de forma experimental, permitindo a identificação autoral de obras para o instrumento. Foi identificado um elenco de cavaquinistas que protagonizaram o referido processo de inovação.

Entre os instrumentistas que desenvolveram a arte de compor e solar no cavaquinho, destacamos Waldir Azevedo que explorou as potencialidades e facilidades sonoras do instrumento, desenvolvendo uma técnica que ficou como herança para todos nós cavaquinistas. Com suas composições, o cavaquinho ganhou popularidade e definitivamente assumiu um patamar de instrumento solista. Seu trabalho é determinante na atual prática do cavaquinho brasileiro.

$\mathrm{Na}$ minha leitura, alguns fatores foram decisivos para tal sucesso do cavaquinho na nossa música. Sua sonoridade aguda é agradável, não é estridente; seu molejo, ginga, balanço, swing, enfim, sua levada rítmica se encaixa em qualquer tipo de música. Além disso, seu tamanho reduzido lhe confere grande portabilidade, que facilita a locomoção do músico, que pode assim andar e tocar ao mesmo tempo, como acontece nas procissões folclóricas. E mais, comparado com outros instrumentos musicais, o cavaquinho é relativamente barato, fato que o torna disponível a todas as camadas sociais. 
Finalizar esse trabalho me proporcionou um conhecimento sobre o que é o cavaquinho, sua história, sua organologia, seus instrumentos ancestrais, sua trajetória até o Brasil e sua participação na construção da nossa cultura.

Pesquisar e emitir ideias sobre o cavaquinho foi, para mim, muito coerente e prazeroso, visto que me dedico a esse instrumento desde 1977 e sempre fui fascinado pelo som que ele produz e pelo efeito que ele provoca nos ouvintes. "O interesse pela música como objeto de deleite fornece impulso primordial para muitos, se não para a maioria dos musicólogos. Esse interesse pode ser chamado de crítico" (MENDEL apud KERMAN, 1987, p. 32).

Essa investigação me fez refletir, ponderar e entender como se dão as transformações sociais, históricas e culturais que culminaram na formação de um modo de tocar o cavaquinho brasileiro, tradicional e com características próprias. E ainda me fez ter consciência de que a música está em constante metamorfose e que a cada dia pode surgir uma inovação. Mais ainda, entendi que entre tradição e inovação não existe separação, elas caminham juntas. Estou certo de que tais conhecimentos serão de grande valia na minha carreira de músico, compositor e professor de cavaquinho, e, diante de tudo o que foi pesquisado, estudado e disponibilizado nesse trabalho, espero ter contribuído para um melhor entendimento sobre o papel do cavaquinho na música brasileira. Uma análise mais profunda sobre o assunto poderá revelar outras informações importantes sobre esse instrumento tão representativo em nossa cultura. 


\section{REFERÊNCIAS}

ALVARENGA, Oneyda Paoliello de. Música Popular Brasileira. Porto Alegre: Editora Globo, 1950.

ANDRADE, Mário de. Dicionário Musical Brasileiro. São Paulo:Editora Itatiaia, 1989.

ANTONIO, Irati; PEREIRA, Regina. Garoto: Sinal dos Tempos. Rio de Janeiro: Funarte, 1982.

ALBIN, Ricardo Cravo. O Livro de Ouro da MPB A História de Nossa Música Popular e Sua Origem até Hoje. Rio de Janeiro: Ediouro, 2003.

. Dicionário Houaiss Ilustrado Música Popular Brasileira. Rio de Janeiro: Editora Paracatu, 2006.

BERNARDO, Marco Antonio. Waldir Azevedo: Um Cavaquinho na História. Rio de Janeiro: Irmãos Vitale, 2004.

BRENET, Michel. Diccionario de La Musica. Barcelona: Editorial Iberia S.A., 1981.

CANDÉ, Roland de. Historia Universal de La Musica. Madrid: Aguilar S.A. de Ediciones, 1981.

CASCUDO, Luis da Câmara. Dicionário do Folclore Brasileiro. 12a Edição, São Paulo: Global Editora, 2012.

CASSOLI, Camilo, FALCÃO, Luiz Augusto. Frevo 100 Anos de Folia. São Paulo: Timbro. 2007.

CASTRO, Ruy. Carmen: uma Biografia. São Paulo: Companhia das Letras, 2005.

CAZES, Henrique Leal. Coleção Folha Raízes da Música Popular Brasileira. São Paulo: Editora MEDIAfashion, 2010. Escola Moderna do Cavaquinho. Rio de Janeiro: Lumiar Editora, s/d. Choro: Do Quintal ao Municipal. Rio de Janeiro: Ed. 34, 2005.

CESAR, Ana Claudia. O Cavaquinho Encantado de Waldir Azevedo. Curitiba: Editora Prismas Ltda, 2013.

Coleção História da Música Popular Brasileira - Grandes Compositores - João Bosco e Aldir Blanc. São Paulo: Abril Cultural, 1982.

CORREA, Ângelo (Budega). História do Cavaquinho no Brasil. Cabo Frio: Secretaria Municipal de Cultura, 2008.

CORTE, A. Della, e GATTI, G. M. Diccionario de La Musica. Buenos Aires: Ricordi Americana Sociedade Anônima Editorial e Comercial, 1950. 
DIAS, Jorge, O Cavaquinho, Estudo de Difusão de um Instrumento Musical Popular. Anais do Congresso Internacional de Etnografia. Santo Tirso, 1963.

Dicionário Aurélio da Língua Portuguesa. São Paulo: Editora Fronteira, 2003.

Dicionário Grove de Música: edição concisa/editado por Stanley Sadie; editora assistente, Alison Latham; tradução, Eduardo Francisco Alves. - Rio de Janeiro: Jorge Zahar Ed. 1994.

DINIZ, André. Almanaque do Choro, a história do chorinho, o que ouvir, o que ler, onde curtir. $3^{\text {a }}$ Edição, Rio de Janeiro: Jorge Zahar Editor Ltda, 2008.

Almanaque do Samba, a história do samba, o que ouvir, o que ler, onde curtir. $4^{\text {a }}$ Edição, Rio de Janbeiro: Jorge Zahar Editor Ltda, 2010.

DOURADO, Henrique Autran. Dicionário de termos e expressões da música. São Paulo: Editora 34, 2004.

EFEGÊ, Jota. Figuras e Coisas da Música Popular Brasileira, vol. 1. Rio de Janeiro: Funarte, 1980.

, Figuras e Coisas da Música Popular Brasileira. Rio de Janeiro: Funarte, 2007. , Ameno Resedá: O Rancho que Foi Escola. $2^{a}$ Edição, Rio de Janeiro: Funarte, 2009.

FILHO, Ivaldo Gadelha de Lara. O Choro dos Chorões de Brasília. Dissertação de Mestrado, Universidade de Brasília, Brasília, 2009.

Grove's Dictionary of Music and Musicians. London: MacMillian \& COLTD. New York: St. Martin's Press. 1954.

GUERRA-PEIXE. Nova História da Música Popular Brasileira - Capiba e Nelson Ferreira. São Paulo: Abril Cultural, 1978.

HENRIQUE, Luís L. Instrumentos Musicais. Lisboa: Fundação Calouste Gulbenkian, 2006.

HOY, David Cousen. Foucault Modern or Postmodern in After Foucault; Humanistic Knowledge, Postmodern Challengers: New Bruswick NJ, Ed. Jonathan Arac, Rutgers Univesity Press, 1988, p. 28.

ISAACS, Alan, MARTIN, Elizabeth. Dicionário de Música. Rio de Janeiro: Zahar, 1985.

KERMAN, Joseph. Musicologia. São Paulo: Editora Martins Fontes, 1987.

KAUTZMANN, Maria Eunice Müller. Cavaquinho-Poesias. Montenegro: Editora Gehlen, 1969.

LAROUSSE, Delta. Volumes IV. Rio de Janeiro: Editora Delta, 1970.

LIMA, Rossini Tavares de. Abecê de Folclore. 6a Edição, São Paulo: Editora Ricordi, 1985.

LOUZAO, Ricardo Henrique Luis. La Guitarra Mágica: Manual Argentino de La Guitarra. Buenos Aires: Papiros, 2009. 
MACHADO, Afonso e MARTINS, Jorge Roberto. Na Cadência do Choro. Rio de Janeiro: Novas Edições, 2006.

MELO, Guilherme Teodoro Pereira de. A Música no Brasil. Salvador:

Tipografia São Joaquim, 1908.

MELlO, Zuza Homem de. Enciclopédia da Música Brasileira; Samba e Choro. São Paulo: Publifolha, 2000. , Enciclopédia da Música Popular Brasileira; Popular Erudita e Folclórica. São Paulo: Publifolha, 1998.

MOURA, Jorge Antônio Cardoso. Tradição e Inovação na Prática do Bandolim Brasileiro. Dissertação de Mestrado, Universidade de Brasília. Brasília, 2011.

NAPOLITANO, Marcos. História Cultural da Música Popular. Belo Horizonte: Autêntica, 2005.

NARLOCH, Leandro. Guia Politicamente Incorreto da História do Brasil. São Paulo: Leya, 2011.

NIN, Carlos Galinea. Canta Brasil. Madrid: Ediciones Cubicas, 1990.

Nova História da Música Popular Brasileira. 2ª Edição, São Paulo: Abril Cultural, 1976.

PINTO, Alexandre Gonçalves. O Choro: Reminiscências dos Chorões Antigos. Rio de Janeiro: Funarte, 1936.

SÁ, Paulo. Palheta e Articulação no Bandolim: Uma Contextualização para Compositores, Arranjadores e Instrumentistas. MÚSICA EM CONTEXTO - ano VI, v. 1, dezembro 2012. Brasília: Programa de Pós-Graduação Música em Contexto, Mestrado UnB, 2012.

SAMPAIO, Gonçalo. O Coro das Maçadeiras. Homenagem a Martins Sacramento. Guimarães, 1933.

SANDRONI, Carlos. Feitiço Descente: Transformações do Samba no Rio de Janeiro. São Paulo: Zahar, 2001.

SILVA, Marília T. Barbosa e OLIVEIRA FILHO, Arthur L. Silas de Oliveira, do Jongo ao Samba-Enredo. Rio de Janeiro: Funarte, 1981.

SINZIG, Frei Pedro. Pelo Mundo do Som: Dicionário Musical. $2^{\text {a }}$ Edição, Rio de Janeiro, São Paulo, Porto Alegre: Livraria Kosmos Editora, 1959.

SOUZA, Tarik de. Tem Mais Samba: Das Raízes à Eletrônica. São Paulo: Editora 34, 2003.

The New Grove: Dictionary of Music and Musicians, Macmillan Publisher Limited, 1980, 2001 e 2003.

TEIXEIRA, João Gabriel L. C. e RIOS, Sebastião. A Velha Guarda do Choro no Planalto Central, p.97-105. Goiânia: FCS/UFG, FUNAPE, 2012. 
TINHORÃO, José Ramos. Pequena História da Música Popular: Segundo Seus Gêneros. $7^{\mathrm{a}}$ Edição, São Paulo: Editora 34, 2013.

Os Sons dos Negros no Brasil - Cantos, Danças, Folguedos: Origens. 2a Edição, São Paulo: Editora 34, 2008.

VIANNA, Hermano. O Mistério do Samba. 2ª Edição, Rio de Janeiro: Ed. Zahar, 2012.

WISNIK, José Miguel. Coleção História da Música Popular Brasileira - Grandes Compositores - Chiquinha Gonzaga, Ernesto Nazareth e Zequinha de Abreu. São Paulo: Abril Cultural, 1982.

\section{Sites}

CAZES, Henrique. Ensaios Músicos do Brasil: Uma Enciclopédia. Disponível em <http://ensaios.musicodobrasil.com.br/henriquecazes-ocavaquinho.pdf >. Data de acesso: 03 de dezembro de 2011.

Apanhei-te Cavaquinho $1^{o}$ Episódio. Lisboa: 2012. Disponível em: www.youtube.com/watch?v=30ETxHEAksY. Acessado em 28 de março de 2014.

CORDEIRO, Cruz. Acervo on-line da revista Phono-Arte, página 13, disponível em revistaphonoarte.com.

Depoimento da cavaquinista Luciana Rabello, dado em entrevista a Daniella Tompson, na revista norte-americana Brazzil em abril de 2000. Disponível em:<http://daniellathompson.com/Texts/Depoimentos/Luciana_Rabello.htm> Acesso em: 04/03/15.

Depoimento do cavaquinista Henrique Cazes dado em entrevista a Meri Fraga, na página da Escola de Música da UFRJ, postado em 01/12/2014. Disponível em: $<$ http://www.musica.ufrj.br/index.php?option=com_content\&view=article\&id=1694:201503-11-01-30-40\&catid=55:destaques \&Itemid=149>. Acesso em 24/03/2015.

HENRIQUES, Paula. Manuel Moraes Leva Machete Madeirense a Festival Internacional. <http://www.dnoticias.pt/actualidade/5-sentidos/370881>. Acesso:16/09/ 2013.

NETTL, Bruno. Musical Thinking and Thinking About Music in The Journal of Aesthetics and Arts Criticism, Vol. 52, $\mathrm{N}^{\mathrm{o}} 1$, The Philosophy of Music, p.139-148. Publicado por The American Society of Aesthetics, 1994. Disponível em: <http://www.jstor.org/stable/431592.>Acesso em: 24/04/2014.

NOGUEIRA, Gláucia. Cavaquinho de Cabo Verde.

Disponível no site da Associação Cultural Museu Cavaquinho-Portugal:

$<$ http//www.cavaquinhos.pt/pt/CAVAQUINHO/Cavaquinho\%20cv\%20Historia.htm.> Acesso em: 16/03/2015.

PEREIRA, Júlio. http://www.juliopereira.pt/INSTRUMENTOS/Cavaquinho\%20Historia.htm. Acesso em: 05/12/14. 


\section{Entrevistas:}

Entrevista como cavaquinista e pesquisador Henrique Cazes, concedida em Brasília no dia 22 de agosto de 2013 no Saguão do Hotel Manhatan.

Entrevista com Jorginho do Pandeiro (Jorge José da Silva) cedida no Clube do Choro de Brasília no dia 24 de agosto de 2014.

Entrevista com o trombonista de frevo Raffael Santana da Silva, integrante da Orquestra Vienna de Recife, cedida no Aeroporto de Recife no dia 16 de janeiro de 2015.

Entrevista ao percussionista maranhense Carlos Henrique Lobato Nogueira (Carlos Pial) cedida na Escola de Música de Brasília no dia 22 de janeiro de 2015.

Entrevista ao cavaquinista Júnior Fernandes, via face book, no dia 03 de fevereiro de 2015.

Entrevista ao músico, arranjador, bandolinista e cavaquinista, Marco César de Oliveira Brito, via email: Entrevista sobre cavaquinho para dissertação, enviado por mcbandolim@hotmail.com e recebido por carrapadocavaquinho@yahoo.com.br no dia 20 de fevereiro de 2015.

Entrevista ao músico e arranjador João Ferreira cedida na Escola de Música de Brasília em 04 de março de 2015. 